University of New Hampshire

University of New Hampshire Scholars' Repository

Earth Systems Research Center

Institute for the Study of Earth, Oceans, and

Space (EOS)

$11-1-1991$

\title{
Potential net primary productivity in South America: application of a global model
}

\author{
J. W. Raich \\ E. B. Rastetter \\ Jerry M. Melillo \\ Marine Biological Laboratory \\ David W. Kicklighter \\ Marine Biological Laboratory (MBL) \\ P. A. Steudler
}

See next page for additional authors

Follow this and additional works at: https://scholars.unh.edu/ersc

Comments

This is an article published by Ecological Society of America (ESA) in Ecological Applications in 1991, available online: https://dx.doi.org/10.2307/1941899

\section{Recommended Citation}

Raich, J., Rastetter, E., Mellilo, J., Kicklighter, D., Steudler, P., Peterson, B., Grace, A. L., Moore, B. III and C. J. Vorosmarty (1991) Potential net primary productivity in South America: application of a global model, Ecological Applications, 1: 399-429. https://dx.doi.org/10.2307/1941899

This Article is brought to you for free and open access by the Institute for the Study of Earth, Oceans, and Space (EOS) at University of New Hampshire Scholars' Repository. It has been accepted for inclusion in Earth Systems Research Center by an authorized administrator of University of New Hampshire Scholars' Repository. For more information, please contact Scholarly.Communication@unh.edu. 


\section{Authors}

J. W. Raich, E. B. Rastetter, Jerry M. Melillo, David W. Kicklighter, P. A. Steudler, B. J. Peterson, Annette L. Schloss, Berrien Moore III, and Charles J. Vorosmarty 


\title{
POTENTIAL NET PRIMARY PRODUCTIVITY IN SOUTH AMERICA: APPLICATION OF A GLOBAL MODEL ${ }^{1}$
}

\author{
J. W. Raich, ${ }^{2}$ E. B. Rastetter, ${ }^{3}$ J. M. Melillo, D. W. Kicklighter, \\ P. A. Steudler, AND B. J. Peterson \\ The Ecosystems Center, Marine Biological Laboratory, Woods Hole, Massachusetts 02543 USA
}

\author{
A. L. Grace, B. Moore III, AND C. J. Vörösmarty \\ Center for Complex Systems, Institute for the Study of Earth, Oceans, and Space, \\ University of New Hampshire, Durham, New Hampshire 03824 USA
}

\begin{abstract}
We use a mechanistically based ecosystem simulation model to describe and analyze the spatial and temporal patterns of terrestrial net primary productivity (NPP) in South America. The Terrestrial Ecosystem Model (TEM) is designed to predict major carbon and nitrogen fluxes and pool sizes in terrestrial ecosystems at continental to global scales. Information from intensively studied field sites is used in combination with continental-scale information on climate, soils, and vegetation to estimate NPP in each of 5888 non-wetland, $0.5^{\circ}$ latitude $\times 0.5^{\circ}$ longitude grid cells in South America, at monthly time steps. Preliminary analyses are presented for the scenario of natural vegetation throughout the continent, as a prelude to evaluating human impacts on terrestrial NPP.

The potential annual NPP of South America is estimated to be $12.5 \mathrm{Pg} / \mathrm{yr}$ of carbon $\left(26.3 \mathrm{Pg} / \mathrm{yr}\right.$ of organic matter) in a non-wetland area of $17.0 \times 10^{6} \mathrm{~km}^{2}$. More than $50 \%$ of this production occurs in the tropical and subtropical evergreen forest region. Six independent model runs, each based on an independently derived set of model parameters, generated mean annual NPP estimates for the tropical evergreen forest region ranging from 900 to $1510 \mathrm{~g} \cdot \mathrm{m}^{-2} \cdot \mathrm{yr}^{-1}$ of carbon, with an overall mean of $1170 \mathrm{~g} \cdot \mathrm{m}^{-2} \cdot \mathrm{yr}^{-1}$. Coefficients of variation in estimated annual NPP averaged $20 \%$ for any specific location in the evergreen forests, which is probably within the confidence limits of extant NPP measurements.

Predicted rates of mean annual NPP in other types of vegetation ranged from 95 $\mathrm{g} \cdot \mathrm{m}^{-2} \cdot \mathrm{yr}^{-1}$ in arid shrublands to $930 \mathrm{~g} \cdot \mathrm{m}^{-2} \cdot \mathrm{yr}^{-1}$ in savannas, and were within the ranges measured in empirical studies. The spatial distribution of predicted NPP was directly compared with estimates made using the Miami model of Lieth (1975). Overall, TEM predictions were $\approx 10 \%$ lower than those of the Miami model, but the two models agreed closely on the spatial patterns of NPP in South America. Unlike previous models, however, TEM estimates NPP monthly, allowing for the evaluation of seasonal phenomena. This is an important step toward integration of ecosystem models with remotely sensed information, global climate models, and atmospheric transport models, all of which are evaluated at comparable spatial and temporal scales.

Seasonal patterns of NPP in South America are correlated with moisture availability in most vegetation types, but are strongly influenced by seasonal differences in cloudiness in the tropical evergreen forests. On an annual basis, moisture availability was the factor that was correlated most strongly with annual NPP in South America, but differences were again observed among vegetation types. These results allow for the investigation and analysis of climatic controls over NPP at continental scales, within and among vegetation types, and within years. Further model validation is needed. Nevertheless, the ability to investigate NPP-environment interactions with a high spatial and temporal resolution at continental scales should prove useful if not essential for rigorous analysis of the potential effects of global climate changes on terrestrial ecosystems.

Key words: carbon fluxes; ecosystem simulation model; geographic information system; global model; modelling; net primary productivity; net primary productivity-environment interactions; South America; spatial and temporal patterns.
\end{abstract}

\section{INTRODUCTION}

Net primary productivity (NPP), the net assimilation of $\mathrm{CO}_{2}$ into organic matter by plants, forms an

\footnotetext{
${ }^{1}$ Manuscript received 26 June 1990; revised and accepted 30 January 1991.

${ }^{2}$ Present address: Department of Biological Sciences, Stanford University, Stanford, California 94305 USA.

${ }^{3}$ Send reprint requests to this author.
}

important link between the biosphere and atmosphere, provides the basic energy source for the growth and maintenance processes upon which most organisms depend, and has important influences on soils, water fluxes, nutrient cycles, and climate. Terrestrial NPP totals $\approx 60 \mathrm{Pg}$ of carbon annually (Ajtay et al. 1979 , Olson et al. 1983), and is therefore a major component of the global $\mathrm{C}$ budget. Understanding NPP, its con- 
trols, and its interactions with the physical environment is essential to understanding the biogeochemistry of Earth.

This is particularly true in the face of rapid, dramatic changes in the terrestrial and atmospheric environments. It is estimated that almost $40 \%$ of the world's NPP has been co-opted by humans, or lost due to landuse activities (Vitousek et al. 1986). The burning of fossil fuels has altered the chemistry of the atmosphere; concentrations of atmospheric $\mathrm{CO}_{2}$, for instance, are rising at a rate of $\approx 0.45 \% / \mathrm{yr}$ (Keeling et al. 1989). Increases in $\mathrm{CO}_{2}$ and other atmospheric trace gases may result in increased global temperatures and modified rainfall patterns (Hansen et al. 1981, MacCracken and Luther 1985, Ramanathan 1988), and may directly influence plant growth (Strain and Cure 1985). However, the responses of terrestrial ecosystems to such changes are poorly understood.

Evaluating the potential impacts of land-use, atmospheric, and climatic changes on terrestrial ecosystems requires a detailed understanding of the effects of environmental variables on ecosystem processes, and a methodology for investigating these processes at large scales. A global perspective is required, yet investigative research is conducted in isolated study sites, each with its own unique attributes. This gap between sitespecific research and global questions can be bridged by ecosystem models that integrate the information derived from empirical studies, and extrapolate this information to other locations and through time.

Our objective is to describe the spatial and temporal patterns of net primary productivity in South America, and the environmental variables controlling these patterns. To do this, we use the Terrestrial Ecosystem Model (TEM), a mechanistically based ecosystem simulation model that is specifically designed to estimate carbon and nitrogen cycling rates and standing stocks at continental to global scales. Although we focus on the prediction of terrestrial NPP in South America, other important ecosystem processes are included, and the methodology used is applicable to global analyses. This work is an integral part of a larger research plan directed toward evaluating the impacts of global climate, land-use, and atmospheric changes on the hydrology and biogeochemistry of terrestrial ecosystems, and on atmospheric chemistry. The development of TEM follows completion of a water-balance model (Vörösmarty et al. 1989).

A fundamental concept behind the development of TEM is the idea that we can more successfully predict rates of NPP in terrestrial ecosystems if we model the basic processes controlling productivity and how they are influenced by environmental factors. This technique of process-level, mechanistic modelling is conceptually and methodologically different from the classical techniques of predicting NPP from empirically derived relationships between NPP and climatic vari- ables (e.g., Rosenzweig 1968, Lieth 1973, Meentemeyer et al. 1982), or from mean data derived from studies within specific biomes or life zones (e.g., Whittaker 1975). Predictions from mechanistic models such as TEM are based on our understanding of ecosystem functioning, and should therefore be more reliable than are predictions from other techniques.

Another advantage of mechanistic models is the ability to consider important feedbacks and constraints on elemental fluxes and pools. For instance, TEM is directly linked to a water-balance model (Vörösmarty et al. 1989), so interactions between temperature and moisture availability are explicitly treated. Furthermore, unlike most previous continental- to global-scale carbon-flux models (e.g., Olson et al. 1978, Houghton et al. 1983, Detwiler and Hall 1988), TEM includes both carbon and nitrogen within the same model. This inclusion provides constraints and feedbacks on both $\mathrm{C}$ and $\mathrm{N}$ cycles, and better enables us to consider factors such as the effect of increasing the availability of one element (e.g., increasing atmospheric $\mathrm{CO}_{2}$ ) on the ecosystem as a whole. This work is a direct outgrowth of our previous work on terrestrial carbon cycles (Moore et al. 1981, Houghton et al. 1983, Melillo et al. 1988) and element interactions (Melillo and Gosz 1983, Melillo and Aber 1984, Norby et al. 1986, Rastetter and Shaver 1992).

Our focus on net primary productivity stems from the importance of this flux in atmosphere-biosphere interactions, and a concern that environmental changes may substantially modify the productive capacity of terrestrial ecosystems. Factors influencing rates of NPP have long been studied, enhancing our ability to model the important controlling processes. Nevertheless, our understanding of spatial and temporal patterns of NPP over entire continents is very limited, as is our understanding of the role that different environmental factors play in controlling NPP rates in different locations.

We therefore developed a general model of carbon and nitrogen cycling that can be applied to any terrestrial vegetation. This model, the Terrestrial Ecosystem Model, is described in detail in Appendix 1. Below we provide a summary of the model, and describe the logic behind its conceptualization and the techniques utilized to make spatial predictions for the South American continent. We test our spatial-extrapolation technique by utilizing the data from six different study sites to calibrate the model and to predict independently the NPP within the tropical evergreen forest zone of South America. We then use TEM to estimate potential NPP in all vegetation types throughout South America, and compare our results with those from alternative techniques. Model output is analyzed to define spatial and temporal patterns of NPP in South America, and possible controls over these patterns. Finally, we discuss the limitations of our analysis and highlight needed directions for future research. 


\section{The TerRestrial Ecosystem Model}

The TEM is a process-level ecosystem simulation model that uses spatially referenced information on soils, vegetation, and climate to estimate important $\mathrm{C}$ and $\mathrm{N}$ pool sizes and fluxes at continental to global scales, with a time step of 1 mo. The model is gridcell based, each grid cell being $0.5^{\circ}$ latitude $\times 0.5^{\circ}$ longitude (3090 $\mathrm{km}^{2}$ at the equator). The TEM is a highly aggregated model; vegetation is not segregated into functional tissues, nor is detritus (soil) partitioned into age or quality classes. Both vegetation and detritus are assumed to be distributed homogeneously within grid cells. Each grid cell is classified by vegetation type and soil texture, both of which influence $\mathrm{C}$ and $\mathrm{N}$ flux rates. Seven major vegetation types and four soil texture classes occur in South America. We apply this model under the assumption that all vegetation in South America is natural, and therefore refer to our predictions as potential fluxes. In the current analysis we presume equilibrium conditions with respect to annual changes in $\mathrm{C}$ and $\mathrm{N}$ pools.

\section{An overview of TEM}

The TEM contains five state variables (Fig. 1): carbon in living vegetation $\left(\mathrm{C}_{V}\right)$, nitrogen in living vegetation $\left(\mathrm{N}_{V}\right)$, organic carbon in detritus and soils $\left(\mathrm{C}_{S}\right)$, organic nitrogen in detritus and soils $\left(\mathrm{N}_{S}\right)$, and available, inorganic soil nitrogen $\left(\mathrm{N}_{\mathrm{av}}\right)$. All dead plant materials are included in the soil pools.

Carbon flows through the ecosystem in TEM, with $\mathrm{CO}_{2}$ assimilation by plants (gross primary productivity, GPP) ultimately being balanced annually by the sum of detritus production $\left(L_{\mathrm{C}}\right)$ and plant respiration $\left(R_{A}\right)$ (Fig. 1). Net primary productivity is defined as the difference between gross primary productivity (GPP) and autotrophic respiration $\left(R_{A}\right)$ :

$$
\mathrm{NPP}_{t}=\mathrm{GPP}_{t}-\mathrm{R}_{A t}
$$

where $t$ refers to the time (month) and units are grams of carbon per square metre per month. Detritus production is the only $C$ input to the soil, and equals heterotrophic respiration $\left(R_{H}\right)$ on an annual basis.

While TEM's C cycle has an important linkage to the external environment (i.e., the atmosphere), the $\mathrm{N}$ cycle in TEM is predominantly an internal ecosystem cycle. Annual N uptake by plants (NUPTAKE) is balanced by annual $\mathrm{N}$ losses in detritus production $\left(L_{\mathrm{N}}\right)$. Inputs of $\mathrm{N}$ to the soil are limited to detrital inputs $\left(L_{\mathrm{N}}\right)$, and are presumed equal on an annual basis to net $\mathrm{N}$ mineralization (NETNMIN), the net difference between $\mathrm{N}$ mineralization and $\mathrm{N}$ immobilization in the soil. Mineralization provides the inorganic $N\left(N_{a v}\right)$ available for plant uptake. The $\mathrm{N}$ cycle is leaky: $\mathrm{N}$ inputs in wet and dry deposition and $\mathrm{N}$ losses through leaching, runoff, and trace gas production are presumed to occur, all via the available $\mathrm{N}$ pool (Fig. 1).

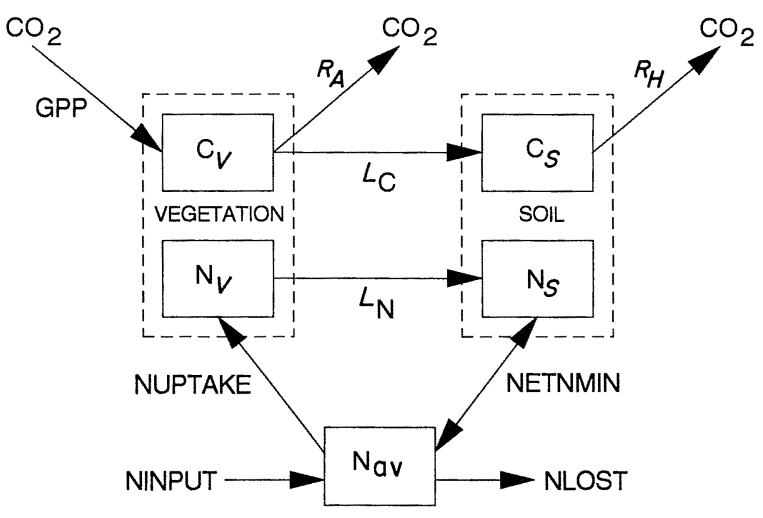

Fig. 1. The Terrestrial Ecosystem Model (TEM). The state variables are: carbon in vegetation $\left(\mathrm{C}_{V}\right)$; nitrogen in vegetation $\left(\mathrm{N}_{V}\right)$; organic carbon in soils and detritus $\left(\mathrm{C}_{S}\right)$; organic nitrogen in soils and detritus $\left(\mathrm{N}_{S}\right)$; and available soil inorganic $\mathrm{N}$ $\left(\mathrm{N}_{\mathrm{av}}\right)$. Arrows show carbon and nitrogen fluxes: GPP, gross primary productivity; $R_{A}$, autotrophic respiration; $R_{H}$, heterotrophic respiration; $L_{\mathrm{C}}$, litterfall C; $L_{\mathrm{N}}$, litterfall N; NUPTAKE, $\mathrm{N}$ uptake by vegetation; NETNMIN, net $\mathrm{N}$ mineralization of soil organic N; NINPUT, $\mathrm{N}$ inputs from outside the ecosystem; and NLOST, N losses from the ecosystem.

Carbon-nitrogen interactions are specifically included in TEM. The relative allocation of effort by the vegetation to $C$ vs. $N$ uptake is modified based on the relative abundances of these two elements in the ecosystem (Rastetter and Shaver 1992). By "allocation of effort" we mean the combined effects of changes in allocation of biomass to the various tissues responsible for $\mathrm{C}$ vs. $\mathrm{N}$ uptake, changes in enzyme concentrations in those tissues, and changes in energy allocated to the $\mathrm{C}$ vs. $\mathrm{N}$ uptake processes. For example, root: shoot allocation relationships may change in response to different atmospheric $\mathrm{CO}_{2}$ concentrations (Acock and $\mathrm{Al}$ len 1985).

Carbon and nitrogen fluxes in TEM (Fig. 1) are controlled by the size of the donor pool, by specific parameters that control exchange rates between compartments, and by environmental variables such as temperature, solar radiation, and moisture conditions. These environmental variables are contained in external data sets organized in a Geographic Information System (GIS). Complete descriptions of the model, the model parameters, the sources of environmental data used to drive the model, and the relationships defined between environmental variables and element flux rates are provided in Appendix 1.

\section{Scaling plot-level information to entire-grid scales}

The specific relationships defined between $\mathrm{C}$ and $\mathrm{N}$ flux rates and environmental driving variables in TEM (Appendix 1) are based on field and laboratory studies conducted at much smaller spatial scales than those at which the model is applied. The prediction of ecosys- 
TABLE 1. Study sites from which data were gathered and used to calibrate the Terrestrial Ecosystem Model. Sites shown with an asterisk $\left(^{*}\right)$ are those used to estimate net primary productivity (NPP) in South America. Other sites in the tropical evergreen forest zone were utilized to explore error terms around NPP predictions. All sites are more fully described in Appendix 2.

\begin{tabular}{llc}
\hline \hline Site name & Vegetation type & \multicolumn{1}{c}{ Location } \\
\hline Banco & Evergreen forest & $5^{\circ} 23^{\prime} \mathrm{N}, 4^{\circ} 02^{\prime} \mathrm{W}$, Ivory Coast \\
*Ducke & Evergreen forest & $2^{\circ} 50^{\prime} \mathrm{S}, 59^{\circ} 57^{\prime} \mathrm{W}$, near Manaus, Brazil \\
El Verde & Evergreen forest & $18^{\circ} 21^{\prime} \mathrm{N}, 65^{\circ} 49^{\prime} \mathrm{W}$, Puerto Rico \\
Kade & $6^{\circ} 09^{\prime} \mathrm{N}, 0^{\circ} 55^{\prime} \mathrm{W}$, Ghana \\
Pasoh & Evergreen forest & $2^{\circ} 58^{\prime} \mathrm{N}, 102^{\circ} 18^{\prime} \mathrm{E}$, peninsular Malaysia \\
San Carlos & Evergreen forest & $1^{\circ} 56^{\prime} \mathrm{N}, 67^{\circ} 03^{\prime} \mathrm{W}$, Amazonas, Venezuela \\
*Chakia & Evergreen forest & $25^{\circ} 20^{\prime} \mathrm{N}, 83^{\circ} \mathrm{E}$, Uttar Pradesh, India \\
*Taita & Deciduous forest & $41^{\circ} 11^{\prime} \mathrm{S}, 174^{\circ} 58^{\prime}$ E, New Zealand \\
*Nylsvley & Temperate forest & $24^{\circ} 39^{\prime} \mathrm{S}, 28^{\circ} 42^{\prime} \mathrm{E}$, South Africa \\
*Guanica & Savanna & $17^{\circ} 55^{\prime} \mathrm{N}, 66^{\circ} 55^{\prime} \mathrm{W}$, Puerto Rico \\
*Nacuñan & Xeromorphic forest & $34^{\circ} 02^{\prime} \mathrm{S}, 67^{\circ} 58^{\prime} \mathrm{W}$, Mendoza, Argentina \\
*Osage & Arid shrubland & $36^{\circ} 57^{\prime} \mathrm{N}, 96^{\circ} 33^{\prime} \mathrm{W}$, Oklahoma, USA \\
\hline
\end{tabular}

tem processes at grid-cell scales $\left(3909 \mathrm{~km}^{2}\right.$ at the equator) therefore requires that these environment-process relationships be modified to account for these differences in scale. Scaling generally results in a flattening of the relationship between process rates and environmental driving variables (O'Neill 1979, Rastetter et al. 1992). We therefore use the following as a working hypothesis; the greater the point-to-point heterogeneity of the independent (environmental or climatic) variable, the lower the range observed in the dependent variable. In other words, we decrease the sensitivity of the relationships in proportion to the expected heterogeneity of the dependent variable.

\section{Application OF THE MODEL}

The TEM was used to predict the spatial distribution of NPP for South America. Although information is available on the spatial distribution of vegetation, soils, and climate throughout South America, specific data on carbon and nitrogen fluxes are available for only a few scattered sites. The TEM was designed to extrapolate this type of site-specific information spatially. This extrapolation was done in two steps. The first was model calibration, during which the values of ratecontrolling parameters were selected so they were consistent with site-specific data for each of the vegetation types in South America. The second step was the spatial extrapolation itself, during which the fully parameterized model was used in conjunction with geographically referenced information on climate, soils, and vegetation to estimate $\mathrm{C}$ and $\mathrm{N}$ fluxes in each of the 5888 non-wetland grid cells of South America.

\section{Model calibration}

Specific parameters control the magnitude of each of the nine $\mathrm{C}$ and $\mathrm{N}$ fluxes included in TEM (Fig. 1), but the values of these parameters cannot be determined directly from published information. We used the information available from intensively studied field sites to estimate the values of each of these rate-controlling parameters by model calibration (i.e., curve fitting). This is analogous to using regression analysis to define parameters that are then used to estimate conditions in regions not specifically investigated. The TEM, however, has an advantage over pure regression in that most of its equations are mechanistically based. It is expected, therefore, that extrapolations with TEM are more reliable than those from regression analysis.

The information used to calibrate TEM was obtained from published studies describing the quantities of $\mathrm{C}$ and $\mathrm{N}$ present in vegetation and soils, and rates of $\mathrm{C}$ and $\mathrm{N}$ fluxes into, out of, and within specific study sites (Table 1). Information not specifically available from published studies was estimated. The specific data used are described in Appendix 2. During model calibration, the data from each site were used to initialize the model, and the model was run using climate data from the same location as independent driving variables. Rate constants controlling each of the major $\mathrm{C}$ and $\mathrm{N}$ fluxes in TEM were then sequentially adjusted until all state variables and predicted annual NPP were constant from year to year, and within $1 \%$ of the literature-based estimate over both 10- and 100-yr model runs. We assumed that data were from sites at equilibrium. The rate constants were assumed to differ among vegetation types, so the model was independently calibrated using data from sites representative of each of the seven vegetation types occurring in South America. Calibration was the final step in defining the values of all parameters needed to use TEM.

\section{Spatial extrapolation of the model}

Spatial extrapolation of the model required the development of georeferenced data sets containing all of the independent variables needed to run the model for each of the 5888 non-wetland grid cells in South America. These data were obtained at different spatial resolutions (Table 2); we converted all the original sources to a $0.5^{\circ}$ by $0.5^{\circ}$ (latitude $\times$ longitude) resolution by combining smaller grid cells or splitting larger grid cells as necessary. Climate data represent long-term mean monthly values, with the exception of cloudiness, which 
TABLE 2. Sources of global data sets used in the Terrestrial Ecosystem Model. All data were converted to a $0.5^{\circ} \times 0.5^{\circ}$ (latitude $\times$ longitude) resolution prior to running the model.

\begin{tabular}{lll}
\hline \hline \multicolumn{1}{c}{ Variable } & \multicolumn{1}{c}{ Source } & $\begin{array}{c}\text { Spatial } \\
\text { resolution }\end{array}$ \\
\hline Air temperature & $\begin{array}{l}\text { Legates and Willmott } \\
(1988)\end{array}$ & $0.5^{\circ} \times 0.5^{\circ}$ \\
Cloudiness & Hahn et al. (1988) & $5.0^{\circ} \times 5.0^{\circ}$ \\
Elevation & NCAR/Navy (1984) & $10^{\prime} \times 10^{\prime}$ \\
Precipitation & Legates and Willmott & $0.5^{\circ} \times 0.5^{\circ}$ \\
& $\quad(1988)$ & \\
Soil texture & FAO/CSRC (undated) & $0.5^{\circ} \times 0.5^{\circ}$ \\
Vegetation & Matthews (1983b) & $1.0^{\circ} \times 1.0^{\circ}$ \\
\hline
\end{tabular}

has a temporal resolution of 3 mo. Missing values in the spatial data sets were replaced by interpolation from surrounding grid cells. All continental-scale information is maintained in georeferenced databases organized in a Geographic Information System (GIS). Information on vegetation type and soil texture was used to correctly apply soil- and vegetation-specific parameter values during model runs (Appendix 1: Tables A1.3 and A1.5). Climate data (temperatures, precipitation, evapotranspiration rates, soil moisture, and solar irradiance) were used as independent driving variables.

We defined seven general vegetation types in South America (Fig. 2), each of which is assumed to be relatively uniform with respect to important $\mathrm{C}$ - and $\mathrm{N}$-cycling parameters. Each vegetation type includes a broad mix of plant community types, and so is only generally comparable to other vegetation classifications. Our tropical evergreen forest category includes broad-leaved evergreen and semi-deciduous forests in both tropical and subtropical regions. Temperate forests in South America are primarily evergreen broad-leaved forests, but include some needle-leaved and deciduous broad-leaved forest types. The xerophytic forest category includes vegetation of the Gran Chaco, the Caatinga of eastern Brazil, and the Mediterranean shrublands of Chile. All non-woody vegetation is classified as grassland, including the Andean paramo.

Wetlands, which were excluded from this analysis, were defined as all grid cells dominated by gleysols, gleyic soils, and histosols as identified by FAO/CSRC (n.d.); all grid cells dominated by swamps as shown on the soils map of South America (FAO-UNESCO 1971); and grid cells dominated by subtropical deltas and lagoons according to Morello (1985). These total 289 grid cells, or $0.8 \times 10^{6} \mathrm{~km}^{2}$ (i.e., $5 \%$ ) of the total 17.8 $\times 10^{6} \mathrm{~km}^{2}$ in South America.

Spatial extrapolation of TEM was accomplished by applying the model one grid cell at a time to the area of interest. The calibrated model was run using climate and soil data from the individual grid cells until a yearto-year equilibrium was achieved (i.e., for $100 \mathrm{yr}$ ). There is no interaction between adjacent grid cells as in some models (e.g., Costanza et al. 1990).

\section{Testing the Model: Estimating NPP IN TROPICAL EVERGREEN Forests}

We assumed that morphologically similar vegetation types interact with their environments in similar ways and, hence, that parameters defined to accurately predict $\mathrm{C}$ and $\mathrm{N}$ fluxes in a single site can be used to predict fluxes in similar types of vegetation in different locations. To test the robustness of this assumption we independently calibrated the model six times for tropical evergreen forest vegetation, using site-specific data from six evergreen forest sites (Table 1). We then estimated NPP in all tropical evergreen forest grid cells of South America six times, each time using a different, independently obtained parameter set, but the same climate and soil texture data.

Mean annual NPP (in terms of carbon) in South American tropical and subtropical evergreen forests, as estimated from these six independent model runs, ranged from 900 to $1510 \mathrm{~g} \cdot \mathrm{m}^{-2} \cdot \mathrm{yr}^{-1}$ with an overall mean of $1160 \mathrm{~g} \cdot \mathrm{m}^{-2} \cdot \mathrm{yr}^{-1}$ (Table 3). Coefficients of variation for the six estimates of annual NPP, determined for each of the 2306 tropical evergreen forest grid cells, ranged from $0.18-0.25$ with a mode of 0.19 .

Field-based estimates of NPP are available from two intensively studied South American evergreen forests, Ducke and San Carlos (Table 1, Appendix 2). Estimates of annual NPP for grid cells containing these two sites varied among the six independent model runs (Table 4), but the field estimates for these sites were well within one standard deviation of the mean of the six modelbased estimates. Coefficients of variation in the independent estimates averaged $\approx 20 \%$. Predicted rates of

TABLE 3. Estimated annual net primary productivity (NPP, as carbon) in tropical evergreen forests of South America as obtained from six independent model runs, each run based on a parameter set defined by calibration of the model to data derived from the calibration site.*

\begin{tabular}{lcccc}
\hline \hline & \multicolumn{3}{c}{$\begin{array}{c}\text { Estimated NPP }\left(\mathrm{g} \cdot \mathrm{m}^{-2} \cdot \mathrm{yr}^{-1}\right) \\
\text { in South American } \\
\text { evergreen forests }\end{array}$} \\
\cline { 2 - 5 } \multicolumn{1}{c}{ Calibration site } & Mean \pm sD & put† & Range \\
\hline Banco (Ivory Coast) & $1510 \pm 160$ & 1370 & $650-1740$ \\
Ducke (Brazil) & $970 \pm 130$ & 1060 & $360-1150$ \\
El Verde (Puerto Rico) & $900 \pm 90$ & 1040 & $350-1040$ \\
Kade (Ghana) & $1320 \pm 120$ & 1150 & $620-1510$ \\
Pasoh (peninsular & $1180 \pm 160$ & 1300 & $480-1460$ \\
$\quad$ Malaysia) & $1110 \pm 130$ & 1240 & $440-1300$ \\
San Carlos (Venezuela) & Mean of six model runs & $1160 \pm 130$ & & $500-1350$ \\
\hline
\end{tabular}

* Data from the calibration site were also used to initialize the state variables prior to running the model. For each model run NPP was estimated for each of the 2306 evergreen forest grid cells in South America. The mean NPP was also calculated for each grid cell $(n=6$ per grid cell), giving the estimates shown in the final row. All statistical parameters are based on $n=2306$

$\dagger$ Refers to the literature-based NPP estimate that was used to calibrate the model for that site. 


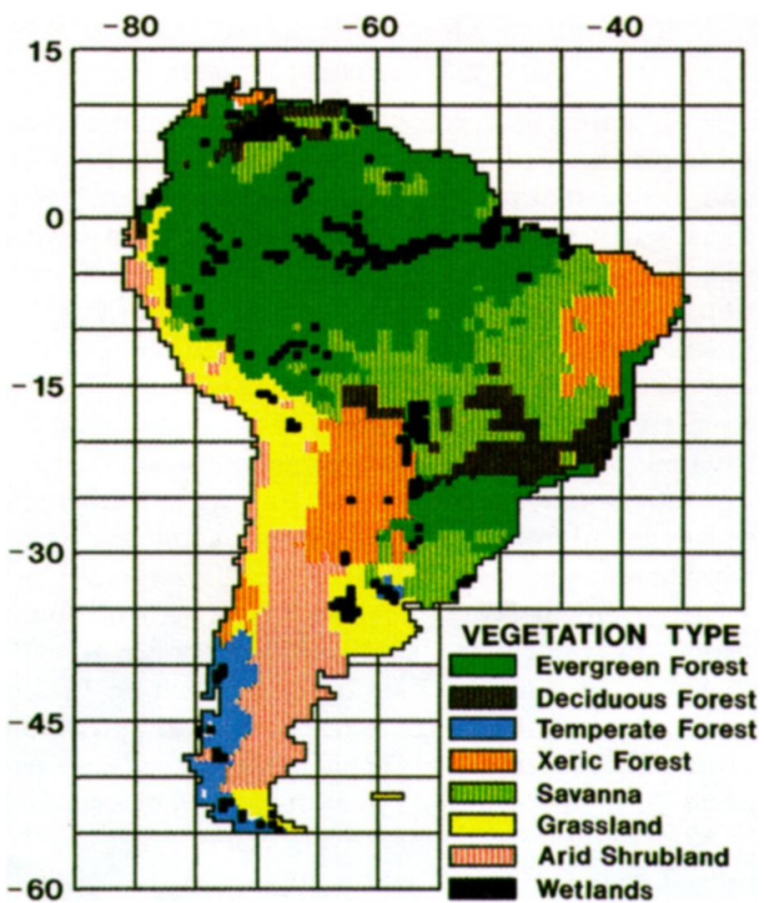

Fig. 2. Potential natural vegetation types of South America as defined for the Terrestrial Ecosystem Model. This map was derived from Matthews (1983b) and Morello(1985). Each vegetation type is presumed to have unique properties with respect to carbon and nitrogen cycling processes, and is presumed to interact with the environment in a unique fashion.

NPP in San Carlos were consistently greater than those in Ducke, as expected from the field-based estimates (Table 4).

We did not have sufficient information to do similar tests in all seven vegetation types, but most NPP in South America occurs in the tropical evergreen forest zone. The independently derived parameter sets did differ, and therefore provided different estimates of NPP when extrapolated to all evergreen forest grid cells. However, coefficients of variation in the annual NPP estimates were $\approx 20 \%$, which is well within the error limits of field-measured rates of NPP. We therefore conclude that TEM can be utilized to estimate regional patterns of NPP in South America.

\section{Estimated Net Primary Productivity IN SOUTH AMERICA}

We next applied TEM to the whole of South America, utilizing the data from individual study sites to calibrate the model for each of our seven vegetation types (Table 1, Appendix 2). The vegetation-specific rate constants used are shown in Table A3. Data from the Ducke (Brazil) site was used to calibrate the model for the tropical evergreen forests because Ducke is centrally located within the evergreen forest zone of South America. Monthly estimates of NPP were made for each of the 5888 non-wetland grid cells in South Amer-

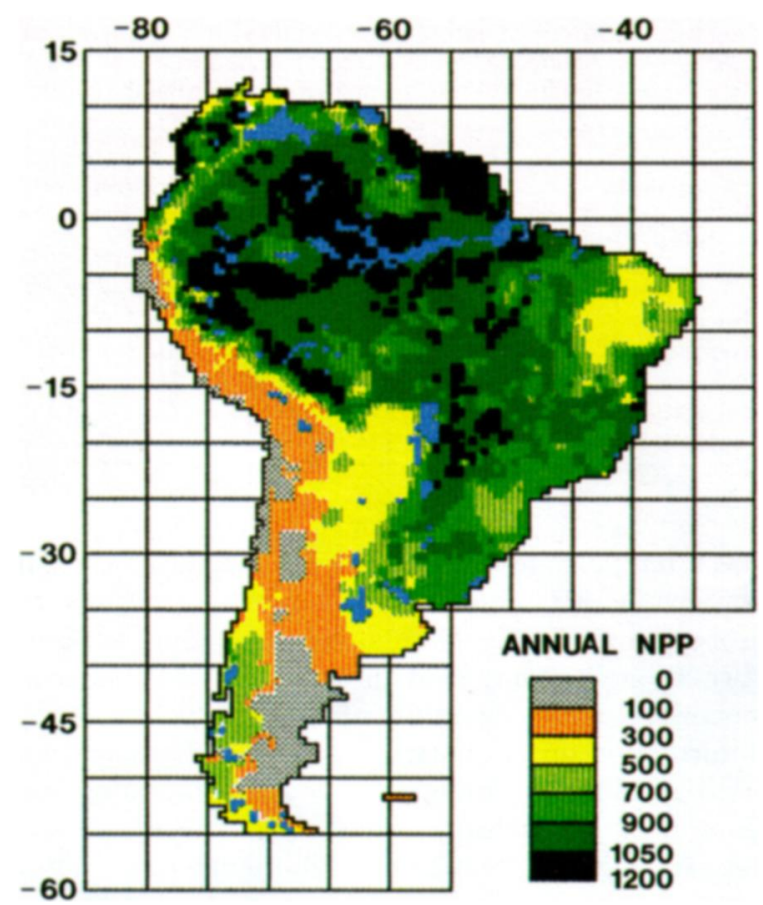

FIG. 3. Potential annual net primary productivity (NPP, as carbon) in South America as determined by the Terrestrial Ecosystem Model. All vegetation is assumed to be mature and undisturbed by human land-use activities. Units are grams of carbon per square metre per year.

ica, with the sum of the monthly estimates for the 100th yr being considered the potential annual NPP.

\section{Annual net primary productivity}

Estimated rates of potential annual NPP in South America range from $40 \mathrm{~g} \cdot \mathrm{m}^{-2} \cdot \mathrm{yr}^{-1}$ of $\mathrm{C}$ in the coastal desert of Peru to a maximum of $1190 \mathrm{~g} \cdot \mathrm{m}^{-2} \cdot \mathrm{yr}^{-1}$ of $\mathrm{C}$ in south-central Brazil (Fig. 3, Table 5). The highest and lowest annual rates are predicted to occur in the savanna and arid shrubland zones, respectively, but in all vegetation types there is substantial variation in predicted NPP rates across the South American landscape (Fig. 3). This variation is due to the heterogeneity of environmental conditions in South America. The TEM does not simply extrapolate the NPP rate of the calibration site to all similar vegetation (Tables 3 and 5). Rather, the calibration data define the potential NPP of a given climate regime; TEM extrapolates from this regime to estimate NPP for the specific environmental conditions of each location. The spatial resolution of TEM's predictions (Fig. 3) is therefore based on the spatial resolution of the underlying environmental data.

A comparison of TEM-estimated rates of NPP in South America with published summaries of NPP studies (Table 6) indicates that estimated annual NPP is within observed values for most vegetation types. 
TABLE 4. Potential annual net primary productivity (NPP as carbon) in grid cells containing the Ducke and San Carlos tropical evergreen forest sites, as predicted by the Terrestrial Ecosystem Model. Each estimate is based on an independent model run with the parameter set and the initial conditions defined from the calibration site.

\begin{tabular}{lcc}
\hline & \multicolumn{2}{c}{$\begin{array}{c}\text { Predicted NPP } \\
\left(\mathrm{g} \cdot \mathrm{m}^{-2} \cdot \mathrm{yr}^{-1}\right)\end{array}$} \\
\cline { 2 - 3 } \multicolumn{1}{c}{ Calibration site } & Ducke & San Carlos \\
\hline Banco (Ivory Coast) & 1610 & 1650 \\
Ducke (Brazil) & $*$ & 1090 \\
El Verde (Puerto Rico) & 920 & 990 \\
Kade (Ghana) & 1400 & 1410 \\
Pasoh (peninsular & 1300 & 1360 \\
$\quad$ Malaysia) & 1180 & $*$ \\
San Carlos (Venezuela) & & \\
Five-site mean \pm SD & $1280 \pm 250$ & $1300 \pm 260$
\end{tabular}

* The model correctly estimates NPP (as carbon) at the site for which it was calibrated. The field-based estimates of NPP at Ducke and San Carlos are 1060 and $1240 \mathrm{~g} \cdot \mathrm{m}^{-2} \cdot \mathrm{yr}^{-1}$, respectively.

Predicted NPP in savannas, deciduous tropical forests, and xeromorphic woodlands is higher than most published values from similar vegetation, but few measurements of NPP in these vegetation types exist, and most exclude estimates of belowground NPP. The TEM predictions agree very well with those of Ajtay et al. (1979), who, like us, specifically included recent estimates of belowground NPP.

Measurements of the spatial distribution of NPP in South America are not available for model validation. However, similar estimates of the potential NPP in South America were made by Lieth (1975) and Box (1978) utilizing their Miami model. The Miami model is directly comparable to TEM in that the vegetation is assumed to be natural. However, the Miami model is based on empirically derived relationships between NPP and mean annual temperature and precipitation, and does not include mechanistic feedbacks arising from the interactions between carbon and nitrogen cycles. Therefore, the Miami model represents an entirely different, independent approach to NPP modelling. We used the Miami model, with the same temperature and precipitation data that were used to drive TEM, to independently estimate the potential NPP in each grid cell in South America.

A grid cell by grid cell comparison between potential annual NPP estimates made by TEM and the Miami model indicates that TEM estimates average $\approx 10 \%$ lower than estimates based on annual climate data alone. Estimates made with the Miami model are within $25 \%$ of TEM estimates in most cases, but in some locations TEM predicts much lower NPP rates than does the Miami model (Fig. 4). These discrepancies are explained by the fact that factors other than mean annual temperature and precipitation influence rates of annual productivity. Differences in soil fertility, for instance, cause some locations to have lower rates of

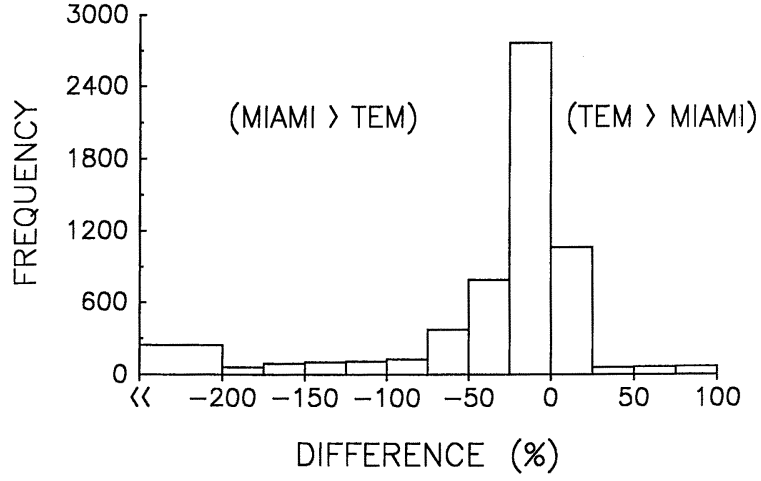

Fig. 4. Frequency distribution of observed differences between predicted rates of annual net primary productivity (NPP), as predicted by the TEM and Miami models. Annual NPP was predicted for each of 5888 grid cells in South America with both models, using identical temperature and precipitation data as independent variables. Shown are TEM predictions minus the Miami predictions, as a percentage of the TEM prediction. Positive differences indicate higher estimates by the TEM, and vice versa.

NPP than would be predicted from climate data alone (Esser 1990). Seasonal distributions of rainfall are also undoubtedly important.

Our estimate of total potential NPP for non-wetland areas of South America is $12.5 \mathrm{Pg} / \mathrm{yr}$ of carbon, or 26.3 $\mathrm{Pg} / \mathrm{yr}$ of organic matter (Fig. 5). This compares favorably to the estimates of Box (1978), which range from 24.4 to $28.8 \mathrm{Pg} / \mathrm{yr}$ (organic matter) for all of South America.

Additional continental-scale estimates with which to make comparisons are lacking, but the comparisons made above demonstrate that estimates of annual NPP made with TEM are comparable with estimates made

TABLE 5. Potential annual net primary productivity (NPP, as carbon) in the major vegetation types in South America, as predicted by the Terrestrial Ecosystem Model. The sample size, $n$, is the number of grid cells dominated by the specified vegetation.

\begin{tabular}{|c|c|c|c|c|}
\hline \multirow[b]{2}{*}{ Vegetation type* } & \multicolumn{4}{|c|}{$\begin{array}{c}\text { Estimated net primary productivity } \\
\left(\mathrm{g} \cdot \mathrm{m}^{-2} \cdot \mathrm{yr}^{-1}\right)\end{array}$} \\
\hline & Mean $\dagger$ & Inputł & Range & $n$ \\
\hline $\begin{array}{l}\text { Tropical evergreen } \\
\text { forest }\end{array}$ & 970 & 1060 & $360-1150$ & 2306 \\
\hline $\begin{array}{l}\text { Tropical deciduous } \\
\text { forest }\end{array}$ & 840 & 700 & $370-1130$ & 380 \\
\hline Temperate forest & 570 & 726 & $310-900$ & 187 \\
\hline Xeromorphic forest & 480 & 555 & $220-820$ & 742 \\
\hline Savanna & 930 & 435 & $490-1190$ & 1020 \\
\hline Grassland & 290 & 470 & $60-590$ & 628 \\
\hline Arid shrubland & 95 & 110 & $40-190$ & 625 \\
\hline
\end{tabular}

* All vegetation is assumed to be mature and unaffected by human land-use activities.

$\dagger$ Mean values presented here are not weighted by grid-cell area, i.e., each grid cell is considered an independent, equally weighted sample.

\# Input refers to the NPP of the site used to calibrate the model for that vegetation zone (Table 1, Appendix 2). 


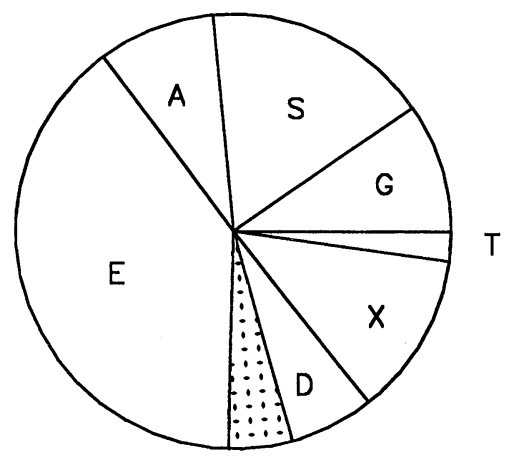

Total Area $=17.8 \times 10^{6} \mathrm{~km}^{2}$
Wetland Area $=0.8 \times 10^{6} \mathrm{~km}^{2}$
A

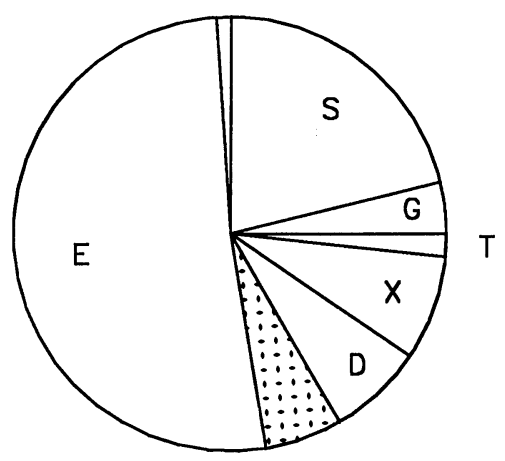

Potential NPP of South America;

Non-wetland Total $=12.5 \mathrm{Pg} / \mathrm{yr}$

FIG. 5. Land areas and potential annual net primary productivity (NPP) in South America, as estimated by the Terrestrial Ecosystem Model. Each slice shows the proportion of the area or NPP dominated by the designated vegetation type, where $\mathrm{A}=$ arid shrublands, $\mathrm{D}=$ tropical deciduous forests, $\mathrm{E}=$ tropical evergreen forests, $\mathrm{G}=$ grasslands, $\mathrm{S}=$ savannas, $\mathrm{T}=$ temperate forests, and $\mathrm{X}=$ xeromorphic forests. Shaded areas show wetlands; the NPP of wetlands is not estimated by TEM.

from global summaries of NPP measurements, and with estimates made by other global models. Estimates made with TEM, however, are mechanistically based and therefore reflect our fundamental understanding of how environmental variables and their interactions influence production, decomposition, and nutrient-cycling processes. The use of a mechanistically based model allows us to investigate both the spatial distribution of NPP and the environmental factors that may limit NPP on continental scales.

Our results (Fig. 3) are the most highly resolved estimates existing of the spatial pattern of NPP in South
America. The potential resolution of TEM is currently $0.5^{\circ}$ latitude $\times 0.5^{\circ}$ longitude, but the actual resolution of our model is limited by the spatial and temporal resolutions of the underlying data sets used to define the environment of South America (Table 2). The NPP of each grid cell is independently predicted, and we present all results at the level of the predictions, but true $0.5^{\circ} \times 0.5^{\circ}$ resolution will only be achieved when all underlying data are resolved to this spatial scale.

The same is true of predicted temporal patterns of NPP. All of our climate data have a 1-mo resolution with the exception of cloudiness, which influences solar

TABLE 6. Potential annual net primary productivity (NPP) in the major vegetation types in South America, as predicted by the Terrestrial Ecosystem Model (TEM), in comparison with summaries of measured NPP rates in similar vegetation types. All values in this table are expressed in terms of organic matter (OM) to eliminate differences in the C:OM ratio used by different authors.

\begin{tabular}{lccccc}
\hline \hline & \multicolumn{5}{c}{ Net primary productivity $\left(\mathrm{g} \cdot \mathrm{m}^{-2} \cdot \mathrm{yr}^{-1}\right)$} \\
\cline { 2 - 5 } \multicolumn{1}{c}{ Vegetation type* } & TEM $\dagger$ & $\begin{array}{c}\text { Lieth } \\
(1973)\end{array}$ & $\begin{array}{c}\text { Whittaker } \\
(1975)\end{array}$ & $\begin{array}{c}\text { Ajtay et al. } \\
(1979)\end{array}$ & $\begin{array}{c}\text { Olson et al. } \\
(1983) \ddagger\end{array}$ \\
\hline Tropical evergreen forest & 2040 & 2000 & 2000 & 2300 & 1680 \\
Tropical deciduous forest & 1780 & 1500 & $-\S$ & 1600 & 1200 \\
Temperate forest & 1200 & 1000 & 1250 & $1400 \|$ & 1260 \\
Xeromorphic forest & 1000 & $800 \pi$ & 700 & $800 \|$ & 770 \\
Savanna & 1950 & $600 \#$ & 900 & $1750^{* *}$ & 1030 \\
Grassland & 620 & $625 \|$ & $600 \dagger \dagger$ & $780 \dagger+\cdot \|$ & 790 \\
Arid shrubland & 200 & 70 & $40 \neq \ddagger$ & 200 & 160 \\
\hline
\end{tabular}

* Definitions of vegetation types differ among authors. The TEM estimates are for South America only, whereas the others represent global means.

† As in Table 5 the TEM estimates are not weighted by area.

$\ddagger$ Area-weighted means calculated from Table 2 in Olson et al. (1983) for comparable vegetation types.

$\S$ No value was reported for this vegetation.

$\|$ Area-weighted mean for two vegetation types combined in this table.

I Value for chaparral, maquis, and brushland.

\# Value for woodlands.

** Area-weighted mean for four savanna types.

†† Refers to temperate grasslands only.

杮 Refers to deserts and semi-deserts. 
radiation. All calculations are made on a monthly basis, and indeed each month is unique, but the actual temporal resolution of our model is $>1$ mo due to the coarse temporal resolution of our cloudiness data (Table 2). Nevertheless, TEM operates at a monthly time step, and the monthly predictions provide highly resolved estimates of the seasonal patterns of NPP in South America.

\section{Seasonality of net primary productivity}

The TEM estimates of NPP are among the most temporally resolved estimates of continental-scale NPP in existence (e.g., Figs. 6 and 7). This is a very important step in the modelling of NPP because seasonality is a dominant characteristic of most ecosystems. Furthermore, many current global climate and atmospheric-transport models have monthly time steps, and remotely sensed data are often summarized on a monthly basis. The development of a monthly ecosystem model therefore enhances our capability to link terrestrial processes with these other information sources, and provides information at a time step compatible with these other efforts.

For example, we can directly compare the estimates of NPP, decomposition, and net ecosystem production made with TEM to similar estimates made by Fung et al. (1987) for a $4^{\circ}$ latitude $\times 5^{\circ}$ longitude grid cell in the heart of the Amazon Basin. Predictions made by TEM, averaged over the same area, are of the same magnitude as those of Fung et al. (1987), but TEM predictions show a greater seasonality of flux rates (Fig. 8). The spatial resolution of the two models is not the same, but additional comparisons of this nature will enhance our ability to both understand and predict important ecosystem processes at very large scales. Further development of remote-sensing tools and analytical techniques will also enhance our ability to directly test model predictions against measured properties such as seasonal changes in atmospheric $\mathrm{CO}_{2}$.

There is virtually no available information on the actual seasonal distribution of NPP in most vegetation types of South America, so we cannot currently test the accuracy of TEM's seasonal NPP estimates. Furthermore, a complete sensitivity analysis has not been conducted on the parameters defined in TEM. Despite these shortcomings, TEM predictions of the seasonal distribution of NPP in South America (Figs. 6 and 7) offer possible insight into the ways in which climatic factors may control NPP in different vegetation types and in different regions of South America.

\section{Climatic Factors Controlling Rates OF Production}

\section{Annual net primary productivity}

To investigate the role that different climatic variables may play in controlling rates of NPP across the South American landscape, we analyzed relationships between predicted annual NPP and mean annual climate data. We randomly selected 50 grid cells from each of the seven vegetation types in South America, and compared NPP rates in these 350 grid cells with climate variables using Pearson's product-moment correlation technique (SAS Institute 1985). Climatic variables included in the analysis were: mean annual air temperature, annual irradiance of photosynthetically active radiation (PAR), annual rainfall, mean annual soil moisture, and estimated annual evapotranspiration (EET). Comparisons were made for all vegetation types combined $(n=350)$ and on a vegetation basis ( $n=50$ per vegetation type). These analyses do not provide definitive answers to the question "What controls rates of NPP on continental scales?," but do provide valuable insight into potential controls, and provide preliminary answers in the form of working hypotheses.

On a continental basis predicted annual NPP correlates most highly with estimated annual evapotranspiration (Table 7), which expresses the interaction between temperatures and moisture availability to plants. A close relationship between plant productivity and evapotranspiration was previously shown by Rosenzweig (1968), and annual evapotranspiration was used to estimate global NPP by Lieth (1975). In our study, strong positive correlations also exist between predicted annual NPP and annual rainfall and mean annual soil moisture, indicating that moisture availability is the dominant factor controlling the spatial distribution of NPP in South America. However, the importance of specific climatic variables differs among vegetation types (Table 7). The spatial distributions of estimated annual NPP in tropical deciduous forests, savannas, and xeromorphic forests correlate most highly with mean annual soil moisture; in temperate forest with mean air temperature; and in arid shrubland with annual rainfall. The same model is used in all cases; rates of NPP predicted by TEM depend upon the specific climatic conditions of individual locations, as well as the potential production rates of individual vegetation types.

\section{Seasonality of net primary productivity}

Seasonal relationships between climate and NPP were explored by comparing estimated monthly NPP with monthly climatic variables on a grid cell by grid cell basis, using the same 350 randomly selected grid cells used for the annual correlation analysis. The importance of individual climatic variables was determined by tallying the probability that a particular variable was significantly correlated $(P<.01)$ with monthly NPP, based on a total of 50 tests (grid cells) in each vegetation type.

Strong correlations among climatic variables preclude a definitive interpretation of which specific factor controls the seasonal pattern of NPP in most vegetation types, but the interaction of temperature and moisture 

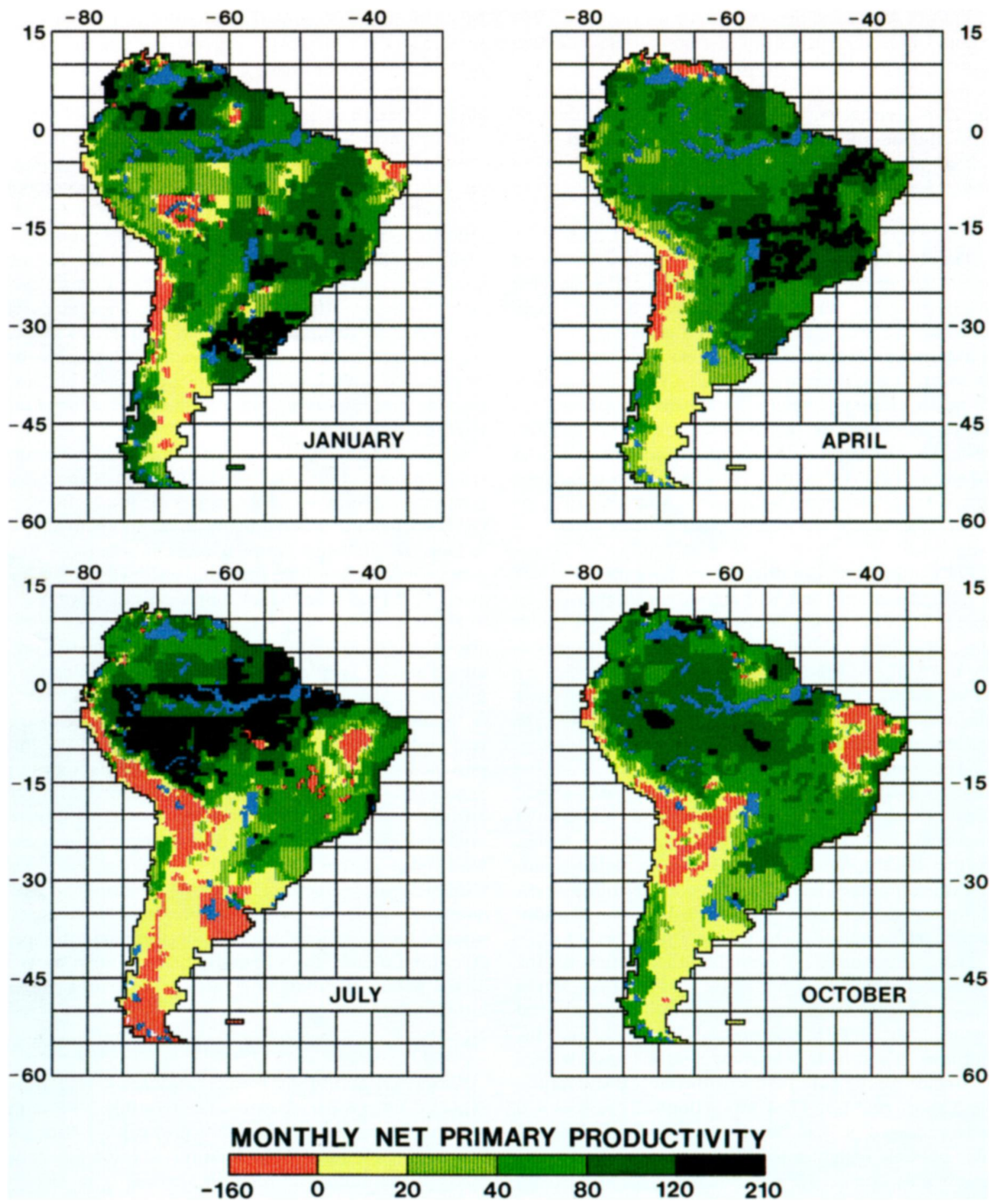

Fig. 6. Potential net primary productivity (NPP) in South America (as carbon) for the months of January, April, July, and October. Values are $\mathrm{g} \cdot \mathrm{m}^{-2} \cdot \mathrm{mo}^{-1}$ of carbon. Negative NPP values (in red) indicate that autotrophic respiration exceeded gross primary production during that month. The blockiness in these figures is due to the poor spatial resolution of the cloudiness data set used to estimate the monthly irradiance of photosynthetically active radiation. 

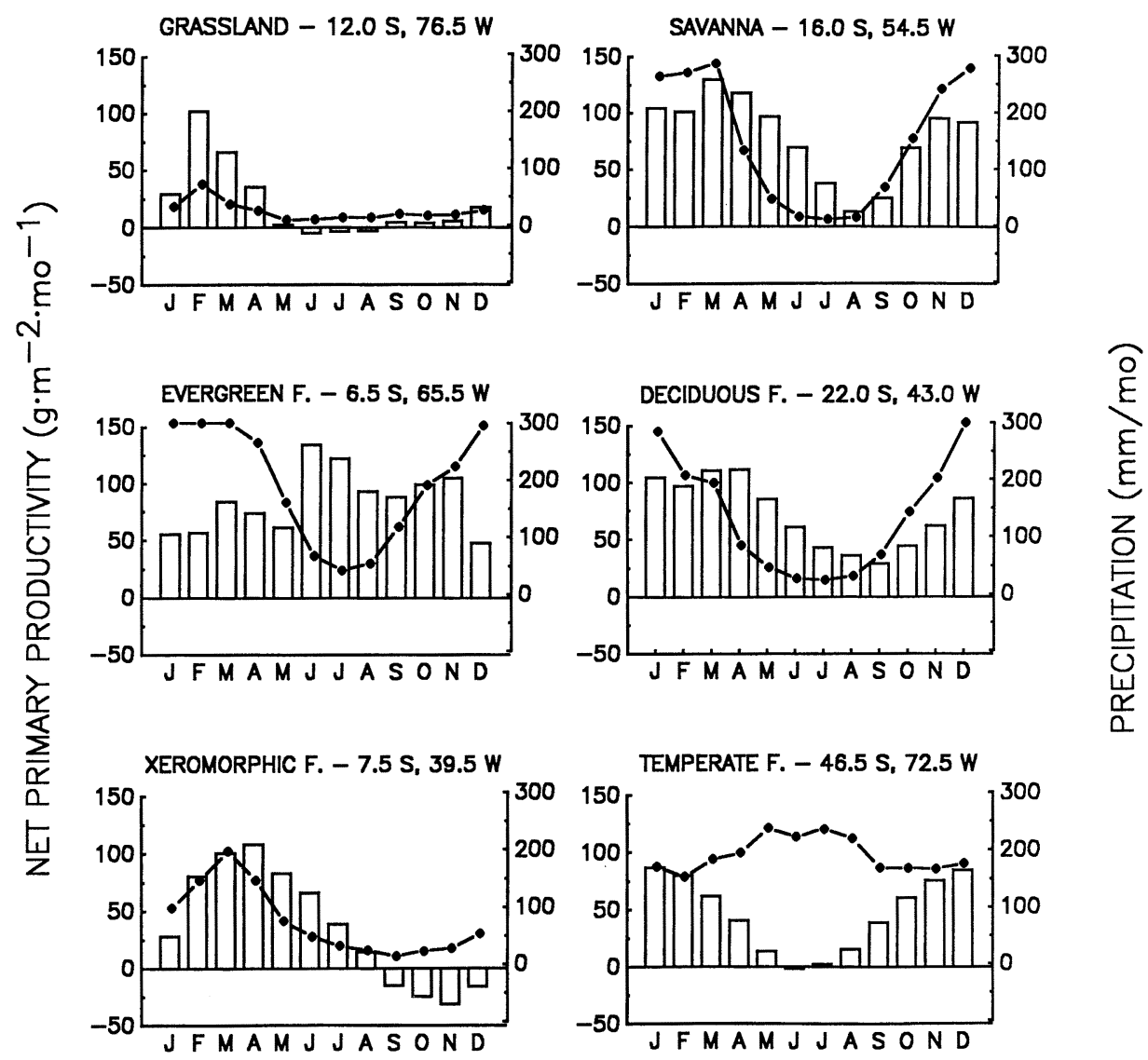

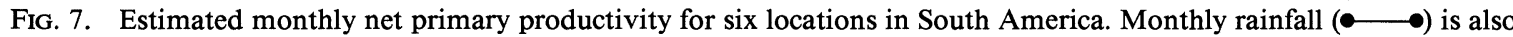
shown for comparison. Cartographic coordinates refer to the southwest corner of $0.5^{\circ}$ latitude $\times 0.5^{\circ}$ longitude grid cells.

availability is clearly important. In the ever-moist Chilean forests, predicted monthly NPP (Fig. 7) correlated very highly with mean monthly temperatures, photosynthetically active radiation (PAR), and evapotranspiration (EET) (Table 8), all of which had similar seasonal patterns. In ever-warm tropical deciduous for- ests, on the other hand, monthly NPP is most frequently correlated with mean monthly soil moisture (Table 8). Lugo et al. (1978) reported that GPP in a tropical dry forest in Puerto Rico is directly related to monthly soil moisture availability. Monthly EET correlated frequently with monthly NPP in five of the

TABLE 7. Correlations between annual environmental conditions and estimated annual net primary productivity for different vegetation types of South America.

\begin{tabular}{lccccc}
\hline \hline & \multicolumn{5}{c}{ Environmental variable* } \\
\cline { 2 - 6 } \multicolumn{1}{c}{ Vegetation } & $\begin{array}{c}\text { Mean annual } \\
\text { temperature }\end{array}$ & Annual PAR & $\begin{array}{c}\text { Annual } \\
\text { rainfall }\end{array}$ & $\begin{array}{l}\text { Mean annual } \\
\text { soil moisture }\end{array}$ & Annual EET \\
\hline & \multicolumn{5}{c}{ Product-moment correlations $\dagger$} \\
Tropical evergreen forest & .56 & -.15 & .64 & .51 & .69 \\
Tropical deciduous forest & NS & -.34 & .51 & .87 & NS \\
Temperate forest & .93 & .63 & NS & .92 \\
Xeromorphic forest & NS & NS & .73 & .84 & .75 \\
Savanna & NS & NS & .58 & .77 & .43 \\
Grassland & .53 & NS & .79 & .73 & .84 \\
Arid shrubland & NS & NS & .80 & .78 & .78 \\
All $(n=350)$ & .59 & NS & .78 & .86 \\
\hline
\end{tabular}

* PAR refers to the irradiance of photosynthetically active radiation and EET refers to estimated actual evapotranspiration.

$\dagger$ Pearson's product-moment correlations based on a randomly selected subsample of 50 grid cells in each vegetation type. Only correlations significant at $P<.01$ are shown; all others are considered nonsignificant (NS). 


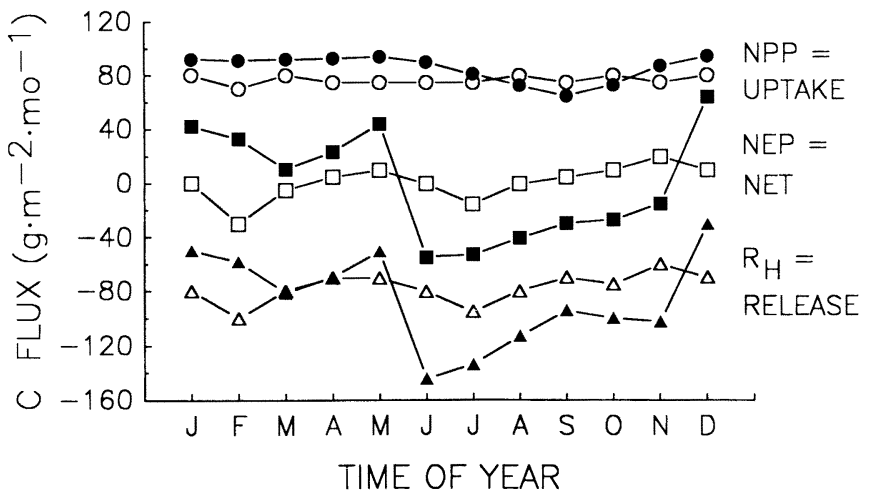

Fig. 8. A comparison of $\mathrm{CO}_{2}-\mathrm{C}$ fluxes as made by the Terrestrial Ecosystem Model (closed symbols) and by Fung et al. (1987) (open symbols) for a $4^{\circ}$ latitude $\times 5^{\circ}$ longitude grid cell in Brazil, centered at $6^{\circ} \mathrm{S}$ latitude and $60^{\circ} \mathrm{W}$ longitude. Fung et al. (1987) used different terms than did we for the same fluxes: "RELEASE" equals heterotrophic respiration $\left(R_{H}\right)$, "NET" equals net ecosystem production (NEP), and "UPTAKE" equals net primary production (NPP). Net ecosystem production is defined as net ecosystem carbon assimilation (i.e., NEP $=$ GPP $-R_{A}-R_{H}$ ). In this figure the signs of fluxes predicted by TEM are reversed to correspond to the atmosphere-oriented model of Fung et al. The estimates of Fung et al. (1987) were taken from their Fig. 4.

seven vegetation types in South America (Table 8), but this may be a direct result of our using EET to drive our phenology model (Appendix 1).

In most cases the specific climatic variables correlated most highly with the spatial distribution of estimated annual NPP are the same variables most frequently correlated with the seasonal pattern of NPP in the same vegetation, but differences also exist (cf. Tables 7 and 8). For instance, the estimated seasonal pattern of NPP in evergreen tropical forests correlated positively with incoming photosynthetically active radiation in $70 \%$ of the tested grid cells. The spatial distribution of annual NPP in these same grid cells correlated negatively with annual PAR. This indicates that the overall level of production in tropical evergreen forests is controlled by factors other than irradiance, but that seasonal differences within specific locations are closely tied to seasonal differences in cloudiness, which controls PAR in tropical regions. These results (Fig. 6) indicate that the evergreen rain forests of the Amazon Basin are strongly seasonal, despite their moist, equatorial climate. This prediction is supported by observations of distinct seasonal variations in litter production (Luizao and Schubart 1987) and water flux (Salati 1985).

\section{DisCUSSION}

The Terrestrial Ecosystem Model (TEM) is one of several regional- to global-scale terrestrial ecosystem models currently being used or developed to investigate biosphere-atmosphere and biosphere-climate interactions. The work initiated by Lieth (1973) and his co-workers has been extended to include $\mathrm{CO}_{2}$ fertilization, soil fertility, and land use (e.g., G. Esser, unpublished manuscript). Seasonal exchanges of $\mathrm{CO}_{2}$ between the terrestrial biosphere and the atmosphere have been modelled for northern latitudes (King et al. 1989), and globally (Gillette and Box 1986, Fung et al. 1987). Emmanuel et al. (1984) developed a global C model to investigate atmospheric $\mathrm{CO}_{2}$ changes resulting from fossil fuel burning and land-use change scenarios. Mechanistically based ecosystem models have been de-

TABLE 8. The probability of a significant, positive correlation between estimated monthly net primary production (NPP, measured as carbon flux) and monthly climate variables for different vegetation types of South America.*

\begin{tabular}{lccccc}
\hline \hline \multirow{2}{*}{ Vegetation } & \multicolumn{5}{c}{ Environmental variable $\dagger$} \\
\cline { 2 - 6 } & Temperature & PAR & Rainfall & Soil moisture & EET \\
\hline Tropical evergreen forest & $\ldots$ & .70 & $\ldots$ & $\ldots$ & $\ldots$ \\
Tropical deciduous forest & $\ldots$ & $\ldots$ & $\ldots$ & .50 & $\ldots$ \\
Temperate forest & .94 & .96 & $\ldots$ & $\ldots$ & .96 \\
Xeromorphic forest & $\ldots$ & $\ldots$ & .50 & $\ldots$ & .52 \\
Savanna & $\ldots$ & $\ldots$ & $\ldots$ & .60 \\
Grassland & .80 & $\ldots$ & .74 & $\ldots$ & 1.00 \\
Arid shrubland & .42 & $\ldots$ & $\ldots$ & .68 \\
\hline
\end{tabular}

* Only correlations significant at $P<.01$ are included, and only these when they were significant in $40 \%$ of the tested grid cells. Each value is based on 50 tests.

† Temperature refers to mean air temperature, PAR to the irradiance of photosynthetically active radiation, and EET to estimated actual evapotranspiration. 
veloped to predict spatial patterns of forest growth and a variety of other ecosystem processes (e.g., Pastor and Post 1986, Running and Nemani 1988). The purposes for which these different models were developed vary, as do the specific modelling techniques used, the assumptions applied, and the spatial and temporal scales considered. The TEM was specifically designed to estimate the spatial and temporal distribution of major $\mathrm{C}$ and $\mathrm{N}$ flux rates and pool sizes at continental to global scales. Such information is difficult or impossible to gather empirically. Models such as TEM therefore provide a means of investigating broad-scale phenomena in a rapidly changing world.

Our analysis would not have been possible without the prior development of geographically referenced data sets of the underlying environmental and climatic characteristics of South America, and the final resolution of our model's predictions is determined by the spatial and temporal scales of these underlying data. All predictions we discuss are based on $0.5^{\circ}$ latitude $\times 0.5^{\circ}$ longitude grid cells and monthly time steps. This is the potential resolution of our predictions, and the scale at which all data are presented. However, the vegetation and cloudiness data sets we used were not resolved at these scales (Table 2), and the actual resolution of our predictions is therefore less than the potential. Nevertheless, the ability to model ecosystem properties at relatively fine temporal and spatial scales is an essential part of understanding and analyzing global processes, and we applied TEM at the finest resolution possible with currently available global data sets.

\section{Potential model validations}

We cannot fully validate our model with currently available information. Validation of TEM will, in fact, be difficult for a variety of reasons. Most importantly, we generated estimates of the net primary productivity (NPP) of South America under the assumption that all vegetation was mature and unaffected by significant human land-use activities. This is clearly not the case, and the model must be modified to include agricultural crops, pastures, plantations, and successional vegetation before a direct comparison with current conditions can be made. Nevertheless, preliminary comparisons with remotely sensed information such as the normalized difference vegetation index (NDVI, Tucker 1979) and microwave data (Choudhury 1987, 1988) can provide valuable, independent checks on the magnitude and spatial distribution of TEM's predictions for sites little affected by land-use changes.

Further analysis of the assumptions underlying TEM can also provide insight into the validity of the model. The principal assumptions in TEM are the relationships proposed between environmental variables and element flux rates, and the parameter values used to define these relationships. Each of these relationships is specifically described, with supporting evidence, in Appendix 1, and can be individually critiqued and compared with empirical data. Such critiques and comparisons are important components of model validation and can provide valuable suggestions for model improvement.

The use of Monte Carlo techniques to place confidence limits on model predictions by propagating uncertainty in parameter estimates is a powerful tool in model testing (e.g., Gardner et al. 1980, Hornberger et al. 1986). However, due to the large number of simulations needed just to make single predictions for each of 5888 grid cells, Monte Carlo analyses for the South American predictions are not computationally feasible at this time. Sensitivity analyses employing Monte Carlo techniques (e.g., Hornberger and Spear 1981, Hornberger and Cosby 1985) also show promise for better defining and constraining parameter values used in TEM. To date we have had little success in the use of these techniques, chiefly because of the large number of parameters defined in the model, and the lack of data on seasonal dynamics included in the model. Further work on defining and constraining the values of parameters defined in TEM is needed.

Despite these drawbacks, preliminary conclusions as to the validity of the model can be made from comparisons with extant information. Model-derived estimates of the mean NPP in different vegetation zones of South America compare very well with the global summary of Ajtay et al. (1979; Table 6). Direct comparison of TEM estimates with similar estimates based on the empirical model of Lieth (1975) also show a good correlation in most grid cells (Fig. 4). Estimates of the annual NPP of South America made with TEM are very similar to those made by Box (1978). Furthermore, the magnitude of carbon fluxes predicted by TEM agrees very well on an annual basis with similar spatially referenced estimates made with the atmospheric $\mathrm{CO}_{2}$ model of Fung et al. (1987; Fig. 8). Therefore, although additional work on validation is needed, predictions made with TEM compare very well with estimates made using other techniques. However, unlike many of these other techniques, TEM may also be used to investigate the responses of natural vegetation to changes in climate, atmospheric $\mathrm{CO}_{2}$, or nutrient inputs.

\section{Limitations of TEM}

A variety of factors influence predictions made by TEM, and uncertainties in any step of the process generate uncertainties in the final predictions. We will specifically discuss limitations in our ability to: (1) accurately define the environmental conditions in South America, (2) include all important driving variables in a single model, (3) empirically define rates of ecosystem processes from field studies, and (4) utilize the information derived at some spatial or temporal scale to model processes at different scales.

The investigation of ecosystem processes across large regions requires both realistic models and the under- 
lying data to drive these models. Our ability to model South American NPP is therefore limited to the use of information that is available for all of South America. The comparatively low spatial and temporal resolution of our cloud cover data set (Hahn et al. 1988) resulted in the blockiness apparent in our predictions of monthly NPP (Fig. 6). Improvements in all of the underlying data sets defining the environmental characteristics of South America will improve our ability to simulate and interpret continental-scale patterns of NPP. Additional information on other factors potentially influencing water and elemental fluxes would enhance our ability to investigate these other factors and their potential importance in controlling NPP rates in South America.

Variables not currently included in either TEM or our soil moisture model, but of potential importance, include soil chemical properties, air humidity regimes, and wind speeds. Esser $(1987,1990)$ argues that incorporation of a soil fertility parameter greatly decreases the unexplained variability in predicting NPP from climate data. Most of the Amazon Basin is covered with phosphorus-deficient soils (Sanchez et al. 1982), so ignoring phosphorus is potentially an important omission in TEM. This potential problem is at least partially overcome by our calibration technique, during which parameter values were defined to correctly predict NPP in an Amazon forest growing on phosphorus-deficient soils. To the extent that parameters are defined by calibration of the model to representative sites, extrapolation of the parameters to similar sites appears to be fully justified. We do, however, need a much better understanding of which specific factors result in sites being truly different. Soil fertility is one potentially important factor, but the extent to which, and how, nutrient limitations affect rates of production in natural vegetation is poorly known.

Continental- to global-scale maps of the phenology of vegetation are also needed. Remote-sensing imagery has greatly enhanced our ability to monitor vegetation phenology over very large areas at the temporal scales considered in TEM (e.g., Justice et al. 1985, Tucker et al. 1985). However, these techniques can only describe existing conditions as influenced by existing climate regimes and land use. Remote-sensing imagery cannot be used to investigate the future. Models such as TEM, which are designed to investigate climate-vegetation interactions in different climate scenarios, require that predictive relationships between climatic factors and vegetation phenology be developed. Our simple, empirical model of plant phenology (Appendix 1: Eq. 9) does so, but much better models are needed. We suggest that remote-sensing imagery be used not only to describe actual events, but to derive basic models that will predict phenology from environmental data.

As with any model, TEM is dependent upon the quality of the data used to calibrate and drive the model. Our ability to investigate broad-scale patterns of terrestrial productivity is therefore constrained by limitations in our abilities to accurately measure ecosystem processes. Despite years of study, there is still a good deal of uncertainty over rates of NPP in terrestrial vegetation. Estimates of tropical grassland production vary by almost four-fold depending upon the techniques employed (Long et al. 1989). Rates of belowground productivity are especially poorly known. Ecosystem properties and productivity rates in tropical deciduous forests, savannas, and other arid or seasonally arid zones have received little research attention. Direct comparison of TEM predictions for six independent model runs in the evergreen forest zone demonstrates that differences in the input data influence the resulting predictions. Nevertheless, coefficients of variation in the resulting predictions were typically $\approx 20 \%$, which is probably within the confidence limits of existing data on NPP.

Given accurate measurements of ecosystem properties, questions of how to utilize this information to make predictions at different spatial or temporal scales will continue, and must be answered before we can obtain better confidence in model predictions. We are testing ways of analyzing daily climate events and mathematically scaling up to monthly time steps. Other techniques may be needed to better account for the spatial variability in vegetation and soils that occurs within grid cells. An alternative approach is to decrease the spatial and/or temporal scale of the model, but the computational costs of doing so must be balanced against the increased value of the information obtained. The TEM predictions currently allow for a detailed investigation of the temporal and spatial distribution of potential NPP in South America.

\section{Future directions}

The TEM is one of several georeferenced, interactive, large-scale models being developed by this group, and follows the development of a continental-scale water-balance model (Vörösmarty et al. 1989). We continue work toward the development of models that can predict trace gas fluxes and nutrient loadings in river runoff from information on ecosystem processes and water fluxes. Extrapolation of these same techniques to the entire terrestrial biosphere will allow for the eventual integration of terrestrial ecosystem models with oceanic and atmospheric models, thereby improving our ability to investigate interactions among the biosphere, atmosphere, and oceans. The potential for such model integration is exemplified by TEM, which required the previous development of a waterbalance model (Vörösmarty et al. 1989). We expect TEM and other terrestrial ecosystem models to prove useful for investigating interactions between climate and vegetation, and possible feedbacks between atmospheric chemistry and ecosystem processes such as NPP.

Among the most pressing needs at this time is the 
continued development of TEM for application to a disturbed landscape. Large land areas have been converted to agricultural uses, and much of the vegetation on uncultivated lands has been cut, grazed, or otherwise modified - to the extent that mature, undisturbed vegetation is the exception rather than the rule. Development of spatially explicit information on the extent of cultivated and secondary lands is therefore a pressing need, as is the modification of our model to describe successional processes.

Also needed is a better understanding of ecosystem processes in wetlands. About $5 \%$ of the $0.5^{\circ}$ latitude $\times$ $0.5^{\circ}$ longitude grid cells in South America are dominated by seasonally or permanently flooded wetlands. Small wetlands not discernible at this scale cover unknown areas. Because ecosystem processes in wetlands differ from those in well-drained locations, we do not know the extent to which these less-common areas influence properties at the continental scale. When model development expands to include trace-gas fluxes (e.g., methane), the importance of wet soils will increase. Including wetlands in our analysis will require development of the underlying data base of wetland locations, types, and areas; the incorporation of soil drainage rates into our water-balance model; and, potentially, the processing of sub-grid-cell information.

It is nevertheless necessary that we use the information currently available to make our best estimates of global processes. Dramatic modifications in global land use and atmospheric chemistry are occurring (e.g., Houghton et al. 1983, Ramanathan 1988, Repetto 1990), and climate changes are predicted (MacCracken and Luther 1985). It is essential that we be able to both comprehend and analyze the effects of these changes, but the potential responses of terrestrial ecosystems to global changes are poorly known. The TEM is designed to address these concerns. While additional validation of the technique and model is needed, TEM provides a means of looking at patterns of NPP and their controls at spatial and temporal scales that are compatible with remotely sensed information and global environmental questions. This represents a major step forward in our ability to investigate ecosystem processes at large scales, and how they may be affected by current or future environmental conditions.

\section{ACKNOWLEDGMENTS}

We thank P. Gildea for her assistance during the early phases of this work. M. Ryan and A. D. McGuire provided useful comments on an earlier draft of the manuscript, and E. A. Griffin provided invaluable editorial suggestions. This work was funded by grants from the National Aeronautics and Space Administration (NAGW-714) and the National Science Foundation (BSR-8718426), and by National Aeronautics and Space Administration contract NAS5-30558.

\section{LiTERATURE Cited}

Aber, J. D., and J. M. Melillo. 1980. Litter decomposition: Measuring relative contributions of organic matter and nitrogen to forest soils. Canadian Journal of Botany 58:416421.
Aber, J. D., and J. M. Melillo. 1982. Nitrogen immobilization in decaying hardwood leaf litter as a function of initial nitrogen and lignin content. Canadian Journal of Botany 60:2263-2269.

Acock, B., and L. H. Allen, Jr. 1985. Crop responses to elevated carbon dioxide concentrations. Pages 53-97 in B. R. Strain and J. D. Cure, editors. Direct effects of increasing carbon dioxide on vegetation. United States Department of Energy, Washington, D.C., USA.

Ajtay, G. L., P. Ketner, and P. Duvigneaud. 1979. Terrestrial primary production and phytomass. Pages 129-181 in B. Bolin, E. T. Degens, S. Kempe, and P. Ketner, editors. The global carbon cycle. John Wiley \& Sons, Chichester, England.

Alexander, M. 1977. Introduction to soil microbiology. Second edition. John Wiley \& Sons, New York, New York, USA.

Asamoa, G. K. 1980. A survey of nitrogen levels in the major soils of Ghana. Pages 171-179 in T. Rosswall, editor. Nitrogen cycling in West African ecosystems. Royal Swedish Academy of Sciences, Stockholm, Sweden.

Bandhu, D. 1970. A study of the productive structure of northern tropical dry deciduous forests near Varanasi. I. Stand structure and nonphotosynthetic biomass. Tropical Ecology 11:90-104.

Bartholomew, M. V., and A. G. Norman. 1946. The threshold moisture content for active decomposition of some mature plant materials. Soil Science Society of America Proceedings 11:270-279.

Bernhard-Reversat, F. 1974. L'azote du sol et sa participation au cycle biogéochimique en forêt ombrophile de Côte-d'Ivoire. Revue d'Écologie et de Biologie du Sol 11: 263-282.

- 1975. Recherches sur l'ecosysteme de la forêt subequatoriale de basse Côte-d'Ivoire. VI. Les cycles des macroelements. Terre et la Vie 29:229-254.

Bernhard-Reversat, F., C. Huttel, and G. Lemée. 1978. Structure and functioning of evergreen rain forest ecosystems of the Ivory Coast. Pages 557-574 in Tropical forest ecosystems. UNESCO, Paris, France.

Bhaumik, H. D., and F. E. Clark. 1947. Soil moisture tension and microbiological activity. Soil Science Society of America Proceedings 12:234-238.

Bokhari, U. G., and J. S. Singh. 1975. Standing state and cycling of nitrogen in soil-vegetation components of prairie ecosystems. Annals of Botany 39:273-285.

Box, E. 1978. Geographical dimensions of terrestrial net and gross primary productivity. Radiation and Environmental Biophysics 15:305-322.

Braun, W. R. H. 1982. Net primary productivity and nitrogen and carbon distribution in two xerophytic communities of central-west Argentina. Plant and Soil 67:315323.

Braun, W. R. H., R. J. Candia, R. Leiva, M. N. Páez, C. R. Stasi, and C. F. Wuilloud. 1978. Productividad primaria aerea neta del algarrobal de Nacuñan (Mendoza). Deserta 5:7-43.

Brown, S., and A. E. Lugo. 1982. The storage and production of organic matter in tropical forests and their role in the global carbon cycle. Biotropica 14:161-187.

Brown, S., A. E. Lugo, S. Silander, and L. Liegel. 1983. Research history and opportunities in the Luquillo Experimental Forest. General Technical Report SO-44. Southern Forest Experiment Station, Forest Service, United States Department of Agriculture, New Orleans, Louisiana, USA. Buschbacher, R. J. 1984. Changes in productivity and nutrient cycling following conversion of Amazon rainforest to pasture. Dissertation, University of Georgia, Athens, Georgia, USA.

Chang, J.-H. 1968. Climate and agriculture: an ecological survey. Aldine, Chicago, Illinois, USA. 
Cheney, W., and D. Kincaid. 1985. Numerical mathematics and computing. Second Edition. Brooks/Cole, Monterey, California, USA.

Choudhury, B. J. 1987. Estimates of primary productivity over the Thar Desert based upon Nimbus-7 37-GHz data; 1979-1985. International Journal of Remote Sensing 8: 1885-1890.

1988. Relating Nimbus-7 $37-\mathrm{GHz}$ data to global land-surface evaporation, primary productivity and the atmospheric $\mathrm{CO}_{2}$ concentration. International Journal of Remote Sensing 9:169-176.

Chung, H.-H., and R. L. Barnes. 1977. Photosynthate allocation in Pinus taeda. I. Substrate requirements for synthesis of shoot biomass. Canadian Journal of Forest Research 7:106-111.

Clark, F. E. 1967. Bacteria in soil. Pages 15-49 in A. Burges and F. Raw, Editors. Soil biology. Academic Press, London, England.

Clarkson, D. T. 1985. Factors affecting mineral nutrient acquisition by plants. Annual Review of Plant Physiology 36:77-115.

Costanza, R., F. H. Sklar, and M. L. White. 1990. Modeling coastal landscape dynamics. BioScience 40:91-107.

Cuevas, E., and E. Medina. 1988. Nutrient dynamics within Amazonian forests. II. Fine root growth, nutrient availability and leaf litter decomposition. Oecologia (Berlin) 76: 222-235.

Davidson, R. L. 1979. Micro-organisms. Pages 267-276 in R. T. Coupland, editor. Grassland ecosystems of the world: analysis of grasslands and their uses. Cambridge University Press, Cambridge, England.

DeAngelis, D. L., R. H. Gardner, and H. H. Shugart. 1981. Productivity of forest ecosystems studied during the IBP: the woodlands data set. Pages 567-672 in D. E. Reichle, editor. Dynamic properties of forest ecosystems. Cambridge University Press, Cambridge, England.

Detwiler, R. P., and C. A. S. Hall. 1988. Tropical forests and the global carbon cycle. Science 239:42-47.

Dutch, M. E., and J. D. Stout. 1968. The carbon cycle in a beech forest ecosystem in relation to microbial and animal populations. Transactions of the Ninth International Congress of Soil Science 2:37-48.

Edmisten, J. 1970. Preliminary studies of the nitrogen budget of a tropical rain forest. Pages H211-H215 in H. T. Odum and R. F. Pigeon, editors. A tropical rain forest: a study of irradiation and ecology at El Verde, Puerto Rico. Office of Information Services, United States Atomic Energy Commission, Washington, D.C., USA.

Emanuel, W. R., G. G. Killough, W. M. Post, and H. H. Shugart. 1984. Modeling terrestrial ecosystems in the global carbon cycle with shifts in carbon storage capacity by landuse changes. Ecology 65:970-983.

Esser, G. 1987. Sensitivity of global carbon pools and fluxes to human and potential climatic impacts. Tellus 39B:245260.

FAO/CSRC. n.d. Soil map of the world, 1:5,000,000. UNESCO, Paris, France. $12^{\circ}$ digitization by Complex Systems Research Center, University of New Hampshire, Durham, New Hampshire, USA.

FAO-UNESCO. 1971. Soil map of the world. Volume IV. South America. UNESCO, Paris, France.

Franken, M., U. Irmler, and H. Klinge. 1979. Litterfall in inundation, riverine, and terra firme forests of central Amazonia. Tropical Ecology 20:225-235.

Frost, P. G. H. 1985. Organic matter and nutrient dynamics in a broadleafed African savanna. Pages 200-206 in J. C. Tothill and J. J. Mott, editors. Ecology and management of the world's savannas. Australian Academy of Science, Canberra, ACT, Australia.

Fung, I. Y., C. J. Tucker, and K. C. Prentice. 1987. Application of advanced very high resolution radiometer vege- tation index to study atmosphere-biosphere exchange of $\mathrm{CO}_{2}$. Journal of Geophysical Research 92(D3):2999-3015. Gardner, R. H., R. V. O'Neill, J. B. Mankin, and D. Kumar. 1980. Comparative error analysis of six predator-prey models. Ecology 61:323-332.

Gates, D. M. 1985. Global biospheric response to increasing atmospheric carbon dioxide concentration. Pages 171-184 in B. R. Strain and J. D. Cure, editors. Direct effects of increasing carbon dioxide on vegetation. DOE/ER-0238. United States Department of Energy, Washington, D.C., USA.

Gillette, D. A., and E. O. Box. 1986. Modeling seasonal changes of atmospheric carbon dioxide and carbon 13 . Journal of Geophysical Research 91(D4):5287-5304.

Greenland, D. J., and J. Kowal. 1960. Nutrient content of the moist tropical forest of Ghana. Plant and Soil 12:154 174.

Hahn, J., S. G. Warren, J. London, and J. L. Roy. 1988 Climatological data for clouds over the globe from surface observations. United States Department of Energy, Oak Ridge, Tennessee, USA.

Hansen, J., D. Johnson, A. Lacis, S. Lebedeff, P. Lee, D. Rind, and G. Russell. 1981. Climate impact of increasing atmospheric carbon dioxide. Science 213:957-966.

Harris, W. F., P. Sollins, N. T. Edwards, B. E. Dinger, and H. H. Shugart. 1975. Analysis of carbon flow and productivity in a temperate deciduous forest ecosystem. Pages 116-122 in Productivity of world ecosystems. National Academy of Sciences, Washington, D.C., USA.

Haynes, R. J. 1986. Uptake and assimilation of mineral nitrogen by plants. Pages 303-378 in R. J. Haynes, editor. Mineral nitrogen in the plant-soil system. Academic Press, Orlando, Florida, USA.

Hornberger, G. M., and B. J. Cosby. 1985. Selection of parameter values in environmental models using sparse data: a case study. Applied Mathematics and Computation 17:335-355.

Hornberger, G. M., B. J. Cosby, and J. N. Galloway. 1986. Modeling the effects of acid deposition: uncertainty and spatial variability in estimation of long-term sulfate dynamics in a region. Water Resources Research 22:12931302.

Hornberger, G. M., and R. C. Spear. 1981. An approach to the preliminary analysis of environmental systems. Journal of Environmental Management 12:7-18.

Houghton, R. A., J. E. Hobbie, J. M. Melillo, B. Moore, B. J. Peterson, G. R. Shaver, and G. M. Woodwell. 1983. Changes in the carbon content of terrestrial biota and soils between 1860 and 1980: a net release of $\mathrm{CO}_{2}$ to the atmosphere. Ecological Monographs 53:235-262.

Hunt, H. W. 1977. A simulation model for decomposition in grasslands. Ecology 58:469-484.

Huttel, C., and F. Bernhard-Reversat. 1975. Recherches sur l'ecosysteme de la forêt subequatoriale de basse Côted'Ivoire. V. Biomasse vegetale et productivite primaire cycle de la matiere organique. Terre et la Vie 29:203-228.

Idso, S. B. 1988. Three phases of plant response to atmospheric $\mathrm{CO}_{2}$ enrichment. Plant Physiology 87:5-7.

Ino, Y., and M. Monsi. 1969. An experimental approach to the calculation of $\mathrm{CO}_{2}$ amount evolved from several soils. Japanese Journal of Botany 20:153-188.

Jackson, M. L. 1958. Soil chemical analysis. Prentice-Hall, Englewood Cliffs, New Jersey, USA.

Jenny, H., S. P. Gessel, and F. T. Bingham. 1949. Comparative study of decomposition rates of organic matter in temperate and tropical regions. Soil Science 68:419-432.

John, D. M. 1973. Accumulation and decay of litter and net production of forest in tropical West Africa. Oikos 24: $430-435$.

Jordan, C. F., W. Caskey, G. Escalante, R. Herrera, F. Montagnini, R. Todd, and C. Uhl. 1982. The nitrogen cycle 
in a "Terra Firme" rainforest on oxisol in the Amazon territory of Venezuela. Plant and Soil 67:325-332.

Jordan, C. F., and G. Escalante. 1980. Root productivity in an Amazonian rain forest. Ecology 61:14-18.

Justice, C. O., J. R. G. Townshend, B. N. Holben, and C. J. Tucker. 1985. Analysis of the phenology of global vegetation using meteorological satellite data. International Journal of Remote Sensing 6:1271-1318.

Kato, R., Y. Tadaki, and H. Ogawa. 1978. Plant biomass and growth increment studies in Pasoh Forest. Malayan Nature Journal 30:211-224.

Keeling, C. D., R. B. Bacastow, A. F. Carter, S. C. Piper, T. P. Whorf, M. Heimann, W. G. Mook, and H. Roeloffzen. 1989. A three-dimensional model of atmospheric $\mathrm{CO}_{2}$ transport based on observed winds. 1. Analysis of observational data. Pages 165-236 in D. H. Peterson, editor. Aspects of climate variability in the Pacific and the Western Americas. Geophysical Monograph 55. American Geophysical Union, Washington, D.C., USA.

Kimball, B. A. 1975. Carbon dioxide and agricultural yield: an assemblage and analysis of 430 prior observations. Agronomy Journal 75:779-788.

King, A. W., R. V. O'Neill, and D. L. DeAngelis. 1989 Using ecosystem models to predict regional $\mathrm{CO}_{2}$ exchange between the atmosphere and the terrestrial biosphere. Global Biogeochemical Cycles 3:337-361.

Klinge, H. 1976a. Nährstoffe, Wasser und Durchwurzelung von Podsolen und Latosolen unter tropischem Regenwald bei Manaus/Amazonien. Biogeographica 7:45-58.

$1976 \mathrm{~b}$. Bilanzierung von Hauptnährstoffen im Ökosystem tropischer Regenwald (Manaus) - vorläufige Daten. Biogeographica 7:59-77.

Klinge, H., and W. A. Rodrigues. 1968. Litter production in an area of Amazonian terra firme forest. Part 1. Litterfall, organic carbon and total nitrogen contents of litter. Amazoniana 1:287-301.

Kramer, P. J. 1983. Water relations of plants. Academic Press, New York, New York, USA.

Larcher, W. 1980. Physiological plant ecology. Second edition. Springer-Verlag, Berlin, West Germany.

Legates, D. R., and C. J. Willmott. 1988. Global air temperature and precipitation data archive. Department of Geography, University of Delaware, Newark, Delaware, USA.

Leopoldo, P. R., W. Franken, E. Salati, and M. N. Ribeiro. 1987. Towards a water balance in the Central Amazonian region. Experientia 43:222-233.

Lieth, H. 1973. Primary production: terrestrial ecosystems. Human Ecology 1:303-332.

- 1975. Modeling the primary productivity of the world. Pages 237-262 in H. Lieth and R. H. Whittaker, editors. Primary productivity of the biosphere. SpringerVerlag, New York, New York, USA.

Lim, M. T. 1978. Litterfall and mineral nutrient content of litter in Pasoh Forest Reserve. Malayan Nature Journal 30: 373-380.

Lommen, P. W., C. R. Schwintzer, C. S. Yocum, and D. M. Gates. 1971. A model describing photosynthesis in terms of gas diffusion and enzyme kinetics. Planta 98:195-220.

Long, S. P., E. Garcia Moya, S. K. Imbamba, A. Kamnalrut, M. T. F. Phedade, J. M. O. Scurlock, Y. K. Shen, and D. O. Hall. 1989. Primary productivity of natural grass ecosystems of the tropics: a reappraisal. Pages 9-20 in M. Clarholm and L. Bergström, editors. Ecology of arable landperspectives and challenges. Kluwer Academic, Dordrecht, The Netherlands.

Lugo, A. E., J. A. Gonzalez-Liboy, B. Cintrón, and K. Dugger 1978. Structure, productivity, and transpiration of a subtropical dry forest in Puerto Rico. Biotropica 10:278-291.

Lugo, A. E., and P. G. Murphy. 1986. Nutrient dynamics of Puerto Rican subtropical dry forest. Journal of Tropical Ecology 2:55-72.
Luizao, F. J., and H. O. R. Schubart. 1987. Litter production and decomposition in a terra-firme forest of Central Amazonia. Experientia 43:259-265.

MacCracken, M. C., and F. M. Luther, editors. 1985. Projecting the climatic effects of increasing carbon dioxide. United States Department of Energy, Washington, D.C., USA.

Manokaran, N. 1980. The nutrient contents of precipitation, throughfall and stemflow in a lowland tropical rain forest in Peninsular Malaysia. Malaysian Forester 43:266-289.

Matthews, E. 1983a. Global vegetation and land use: new high resolution data bases for climate studies. Journal of Climatology and Applied Meteorology 22:474-487.

- $1983 \mathrm{~b}$. Vegetation, land-use and albedo data archive. Institute for Space Studies, NASA-Goddard Space Flight Center, New York, New York, USA.

McCree, K. H. 1966. A solarimeter for measuring photosynthetically active radiation. Agricultural Meterology 3: 353-366.

Medina, E., and E. Cuevas. 1989. Patterns of nutrient accumulation and release in Amazonian forests of the upper Rio Negro Basin. Pages 217-240 in J. Proctor, editor. Mineral nutrients in tropical forest and savanna ecosystems. Blackwell Scientific, Oxford, England.

Meek, D. W., J. L. Hatfield, T. A. Howell, S. B. Idso, and R. J. Reginato. 1984. A generalized relationship between photosynthetically active radiation and solar radiation. Agronomy Journal 76:939-945.

Meentemeyer, V., E. O. Box, and R. Thompson. 1982. World patterns and amounts of terrestrial plant litter production. BioScience 32:125-128.

Melillo, J. M., and J. D. Aber. 1984. Nutrient immobilization in decaying litter: an example of carbon-nutrien interactions. Pages 193-215 in J. H. Cooley and F. B. Golley, editors. Trends in ecological research for the 1980s. Plenum, New York, New York, USA.

Melillo, J. M., J. D. Aber, A. E. Linkins, A. Ricca, B. Fry, and K. J. Nadelhoffer. 1989. Carbon and nitrogen dynamics along the decay continuum: plant litter to soil organic matter. Pages 53-62 in M. Clarholm and L. Bergström, editors. Ecology of arable land. Kluwer Academic, Dordrecht, The Netherlands.

Melillo, J. M., J. R. Fruci, R. A. Houghton, B. Moore III, and D. L. Skole. 1988. Land-use change in the Soviet Union between 1850 and 1980: causes of a net release of $\mathrm{CO}_{2}$ to the atmosphere. Tellus 40B:116-128.

Melillo, J. M., and J. R. Gosz. 1983. Interactions of biogeochemical cycles in forest ecosystems. Pages 177-222 in B. Bolin and R. B. Cook, editors. The major biogeochemical cycles and their interactions. John Wiley \& Sons, Chichester, England.

Miller, R. B. 1963a. Plant nutrients in hard beech. I. The immobilization of nutrients. New Zealand Journal of Science 6:365-377.

1963b. Plant nutrients in hard beech. III. The cycle of nutrients. New Zealand Journal of Science 6:388-413.

1968. Flows and cycles of macro- and micro-elements in a forest soil and its environment. Transactions of the Ninth International Congress of Soil Science 4:323331.

Miller, R. D., and D. D. Johnson. 1964. The effect of soil moisture tension on carbon dioxide evolution, nitrification, and nitrogen mineralization. Soil Science Society of America Proceedings 28:644-647.

Misra, R. 1972. A comparative study of net primary productivity of dry deciduous forest and grassland of Varanasi, India. Pages 279-293 in P. M. Golley and F. B. Golley, compilers. Tropical ecology with an emphasis on organic productivity. University of Georgia, Athens, Georgia, USA. Montagnini, F., and R. Buschbacher. 1989. Nitrification rates in two undisturbed tropical rain forests and three slash- 
and-burn sites of the Venezuelan Amazon. Biotropica 21: 9-14.

Moore, B., R. D. Boone, J. E. Hobbie, R. A. Houghton, J. M. Melillo, B. J. Peterson, G. R. Shaver, C. J. Vörösmarty, and G. M. Woodwell. 1981. A simple model for analysis of the role of terrestrial ecosystems in the global carbon budget. Pages 365-385 in B. Bolin, editor. Carbon cycle modelling. John Wiley \& Sons, Chichester, England.

Morello, J. A. 1985. Grandes ecosistemas de Sudamérica (including map). Fundación Bariloche, Rio Negro, Argentina.

Murphy, P. G., and A. E. Lugo. 1986. Structure and biomass of a subtropical dry forest in Puerto Rico. Biotropica 18: 89-96.

Nadelhoffer, K. J., and J. W. Raich. 1992. Fine root production estimates and belowground carbon allocation in forest ecosystems. Ecology 73, in press.

NCAR/Navy. 1984. Global 10-minute elevation data. Digital tape available through National Oceanic and Atmospheric Administration, National Geophysical Data Center, Boulder, Colorado, USA.

Newbould, P. 1968. Methods of estimating root production. Pages 187-190 in F. E. Eckardt, editor. Functioning of terrestrial ecosystems at the primary production level. UNESCO, Paris, France.

Norby, R. J., J. Pastor, and J. M. Melillo. 1986. Carbonnitrogen interactions in $\mathrm{CO}_{2}$-enriched white oak: physiological and long-term perspectives. Tree Physiology 2:233241.

Nye, P. H. 1961. Organic matter and nutrient cycles under moist tropical forest. Plant and Soil 13:333-346.

Nye, P. H., and P. B. Tinker. 1977. Solute movement in the soil-root system. University of California Press, Berkeley, California, USA.

Odum, H. T. 1970. Summary: an emerging view of the ecological system at El Verde. Pages I191-I289 in H. T. Odum and R. F. Pigeon, editors. A tropical rain forest: a study of irradiation and ecology at El Verde, Puerto Rico. Office of Information Services, United States Atomic Energy Commission, Washington, D.C., USA.

Ogawa, H. 1978. Litter production and carbon cycling in Pasoh Forest. Malayan Nature Journal 30:367-373.

Olson, J. S., H. A. Pfuderer, and Y.-H. Chan. 1978. Changes in the global carbon cycle and the biosphere. Oak Ridge National Laboratory, Oak Ridge, Tennessee, USA.

Olson, J. S., J. A. Watts, and L. J. Allison. 1983. Carbon in live vegetation of major world ecosystems. Environmental Sciences Division Publication Number 1997. Oak Ridge National Laboratory, Oak Ridge, Tennessee, USA.

O'Neill, R. V. 1979. Transmutations across hierarchical levels. Pages 59-78 in G. S. Innis and R. V. O'Neill, editors. Systems analysis of ecosystems. International Co-operative Publishing House, Fairland, Maryland, USA.

Papendick, R. I., and G. S. Campbell. 1981. Theory and measurement of water potential. Pages 1-22 in J. F. Parr, W. R. Gardner, and L. F. Elliott, editors. Water potential relations in soil microbiology. Special Publication Number 9. Soil Science Society of America, Madison, Wisconsin, USA.

Pastor, J., and W. M. Post. 1986. Influence of climate, soil moisture, and succession on forest carbon and nitrogen cycles. Biogeochemistry 2:3-27.

Raich, J. W., and K. J. Nadelhoffer. 1989. Belowground carbon allocation in forest ecosystems: global trends. Ecology 70:1346-1354.

Ramam, S. S. 1975. Primary production and nutrient cycling in tropical deciduous forest ecosystem. Tropical Ecology 16:140-146.

Ramanathan, V. 1988. The greenhouse theory of climate change: a test by an inadvertent global experiment. Science 240:293-299.
Rastetter, E. B., and G. R. Shaver. 1992. A model of multiple element limitation for acclimating vegetation. Ecology 73, in press.

Rastetter, E. B., A. W. King, B. J. Cosby, G. M. Hornberger R. V. O'Neill, and J. E. Hobbie. 1992. Aggregating finescale ecological knowledge to model the coarse-scale attributes of ecosystems. Ecological Applications 2, in press.

Repetto, R. 1990. Deforestation in the tropics. Scientific American 262:36-42.

Risser, P. G., E. C. Birney, H. D. Blocker, S. W. May, W. J. Parton, and J. A. Wiens. 1981. The true prairie ecosystem. Hutchinson Ross, Stroudsburg, Pennsylvania, USA.

Risser, P. G., and W. J. Parton. 1982. Ecosystem analysis of the tallgrass prairie: Nitrogen cycle. Ecology 63:13421351.

Robertson, G. P., and T. Rosswall. 1986. Nitrogen in West Africa: the regional cycle. Ecological Monographs 56:4372.

Rosenzweig, M. L. 1968. Net primary productivity of terrestrial communities: prediction from climatological data. American Naturalist 102:67-74.

Running, S. W., and R. R. Nemani. 1988. Relating seasonal patterns of the AVHRR vegetation index to simulated photosynthesis and transpiration of forests in different climates. Remote Sensing of Environment 24:347-367.

Ryan, M. G. 1991. Effects of climate change on plant respiration. Ecological Applications 1:157-167.

Salati, E. 1985. The climatology and hydrology of Amazonia. Pages 18-48 in G. T. Prance and T. E. Lovejoy, editors. Key environments: Amazonia. Pergamon, Oxford, England.

Salick, J., R. Herrera, and C. F. Jordan. 1983. Termitaria: nutrient patchiness in nutrient-deficient rain forests. Biotropica 15:1-7.

Sanchez, P. A., D. E. Bandy, J. H. Villachica, and J. J. Nicholaides. 1982. Amazon Basin soils: management for continuous crop production. Science 216:821-827.

Saxton, K. E., W. J. Rawls, J. S. Romberger, and R. I. Papendick. 1986. Estimating generalized soil-water characteristics from texture. Soil Science Society of America Journal 50:1031-1036.

Sims, P. L., and R. T. Coupland. 1979. Producers. Pages 49-71 in R. T. Coupland, editor. Grassland ecosystems of the world: analysis of grasslands and their uses. Cambridge University Press, Cambridge, England.

Sims, P. L., J. S. Singh, and W. K. Lauenroth. 1978. The structure and function of ten western North American grasslands. I. Abiotic and vegetational characteristics. Journal of Ecology 66:251-285.

Sommers, L. E., C. M. Gilmour, R. E. Wildung, and S. M. Beck. 1981. The effect of water potential on decomposition processes in soils. Pages 97-117 in J. F. Parr, W. R. Gardner, and L. F. Elliott, editors. Water potential relations in soil microbiology. Special Publication Number 9. Soil Science Society of America, Madison, Wisconsin, USA.

Stigter, C. J., and V. M. M. Musabilha. 1982. The conservative ratio of photosynthetically active to total radiation in the tropics. Journal of Applied Ecology 19:853-858.

Stott, D. E., L. F. Elliott, R. I. Papendick, and G. S. Campbell. 1986. Low temperature or low water potential effects on the microbial decomposition of wheat residue. Soil Biology and Biochemistry 18:577-582.

Strain, B. R., and J. D. Cure, editors. 1985. Direct effects of increasing carbon dioxide on vegetation. DOE/ER-0238. United States Department of Energy, Washington, D.C., USA.

Swaine, M. D., D. Lieberman, and F. E. Putz. 1987. The dynamics of tree populations in tropical forest: a review. Journal of Tropical Ecology 3:359-366.

Tanquilevich, R. F. 1971. Los suelos de la Reserva Ecológica de Ñacuñan. Deserta 2:131-206. 
Thornthwaite, C. W., and J. R. Mather. 1957. Instructions and tables for computing potential evapotranspiration and the water balance. Publications in Climatology. Volume 10, Number 3. Laboratory of Climatology, Drexel Institute of Technology, Centerton, New Jersey, USA.

Tucker, C. J. 1979. Red and photographic infrared linear combinations for monitoring vegetation. Remote Sensing of the Environment 8:127-150.

Tucker, C. J., J. R. G. Townshend, and T. E. Goff. 1985. African land-cover classification using satellite data. Science 227:369-375.

Turton, S. M. 1986. Solar radiation under cloudless skies. Weatherwise 39:223-224.

Uhl, C., and C. F. Jordan. 1984. Succession and nutrient dynamics following forest cutting and burning in Amazonia. Ecology 65:1476-1490.

UNESCO. 1973. International classification and mapping of vegetation. UNESCO, Paris, France.

Van Veen, J. A., and E. A. Paul. 1981. Organic carbon dynamics in grassland soils. 1. Background information and computer simulation. Canadian Journal of Soil Science 61: 185-201.

Vertregt, N., and F. W. T. Penning de Vries. 1987. A rapid method for determining the efficiency of biosynthesis of plant biomass. Journal of Theoretical Biology 128:109-119.

Vitousek, P. M., P. R. Ehrlich, A. E. Ehrlich, and P. A. Matson. 1986. Human appropriation of the products of photosynthesis. BioScience 36:368-373.

Vitousek, P. M., and P. A. Matson. 1988. Nitrogen transformations in a range of tropical forest soils. Soil Biology Biochemistry 20:361-367.

Vitousek, P. M., and R. L. Sanford, Jr. 1986. Nutrient cycling in moist tropical forest. Annual Review of Ecology and Systematics 17:137-167.

Vörösmarty, C. J., B. Moore III, A. L. Grace, M. P. Gildea, J. M. Melillo, B. J. Peterson, E. B. Rastetter, and P. A. Steudler. 1989. Continental scale models of water balance and fluvial transport: an application to South America. Global Biogeochemical Cycles 3:241-265.
Waring, R. H., and W. H. Schlesinger. 1985. Forest ecosystems: concepts and management. Academic Press, Orlando, Florida, USA.

Whitford, W. G., K. Stinnet, and Y. Steinberger. 1988. Effects of rainfall supplementation on microarthropods on decomposing roots in the Chihuahuan Desert. Pedobiologia 31:147-155.

Whittaker, R. H. 1975. Communities and ecosystems. Second edition. Macmillan, New York, New York, USA.

Whittaker, R. H., and G. E. Likens. 1973. Carbon in the biota. Pages 281-300 in G. M. Woodwell and E. V. Pecan editors. Carbon and the biosphere. National Technical Information Service, United States Department of Commerce, Springfield, Virginia, USA.

Williams, K., F. Percival, J. Merino, and H. A. Mooney. 1987. Estimation of tissue construction cost from heat of combustion and organic nitrogen content. Plant, Cell, and Environment 10:725-734.

Wong, S. C., I. R. Cowan, and G. D. Farquhar. 1979. Stomatal conductance correlates with photosynthetic capacity. Nature 282:424-426.

Woodmansee, R. G. 1979. Factors influencing input and output of nitrogen in grasslands. Pages 117-134 in N. R. French, editor. Perspectives in grassland ecology. SpringerVerlag, New York, New York, USA

Woodwell, G. M., and D. B. Botkin. 1970. Metabolism of terrestrial ecosystems by gas exchange techniques: the Brookhaven approach. Pages 73-85 in D. E. Reichle, editor. Analysis of temperate forest ecosystems. Springer-Verlag, Berlin, West Germany.

Yoda, K. 1978. Organic carbon, nitrogen and mineral nutrient stocks in the soils of Pasoh Forest. Malayan Nature Journal 30:229-251.

Yoda, K., and T. Kira. 1982. Accumulation of organic matter, carbon, nitrogen and other nutrient elements in the soils of a lowland rainforest at Pasoh, Peninsular Malaysia. Japanese Journal of Ecology 32:275-291.

\section{APPENDIX 1 \\ The Terrestrial Ecosystem Model}

The Terrestrial Ecosystem Model (TEM, Fig. 1) is a highly aggregated, process-based simulation model of carbon and nitrogen cycling in terrestrial ecosystems. It is grid-cell based, each grid cell being $0.5^{\circ}$ latitude $\times 0.5^{\circ}$ longitude, with no connections among adjacent grid cells. The TEM is designed to investigate interactions among terrestrial ecosystems and environmental variables at continental or global scales, with a maximum time step of one month. The minimum set of environmental variables needed to run the model consists of: vegetation type, soil texture, soil moisture, potential and actual evapotranspiration rates, solar irradiance, cloudiness, precipitation, temperature, and atmospheric $\mathrm{CO}_{2}$ concentrations. These variables control $\mathrm{C}$ and $\mathrm{N}$ fluxes into and out of soils and vegetation, thereby influencing $C$ and $N$ masses in these compartments. Soil moisture and evapotranspiration rates are calculated by our Water Balance Model (Vörösmarty et al. 1989) using the vegetation, soil, elevation, temperature, and precipitation data shown in Table 2 .

All environmental (independent) variables are contained in external data sets (see Table 2) organized in a geographical information system (GIS), with the exception of the atmospheric $\mathrm{CO}_{2}$ concentration, which is assumed to be spatially and temporally constant in current model applications. Additional steps taken to develop or modify these global data sets are described at the end of this appendix. Below we fully describe TEM, the specific relationships defined between environmental variables and element flux rates, and the assumptions made in the model.

\section{State variables}

The TEM contains five state variables: carbon in living vegetation $\left(\mathrm{C}_{V}\right)$, nitrogen in living vegetation $\left(\mathrm{N}_{V}\right)$, organic carbon in detritus and soils $\left(\mathrm{C}_{S}\right)$, organic nitrogen in detritus and soils $\left(\mathrm{N}_{S}\right)$, and available, inorganic soil nitrogen $\left(\mathrm{N}_{\mathrm{av}}\right)$. All dead plant materials are included in the soil pool, and all living plant roots, shoots, and leaves are included in the vegetation pool. We assume that live and dead vegetation are $47.5 \% \mathrm{C}$, a value midway between the commonly used values of $45 \%$ (Whittaker and Likens 1973) and 50\% (Brown and Lugo 1982), and well within the range of reported $C$ contents of vegetation (Ajtay et al. 1979). Soil organic matter is assumed to be $58 \%$ C (Jackson 1958).

The model was applied in this paper to the investigation of mature, natural ecosystems; parameters were defined in such a way that state variables did not change from year to year for sites used to calibrate the model. For predictions at all other sites the model was run continuously until equilibrium conditions existed and all state variables remained vir- 
TABLE A1. State variables, fluxes, and parameters defined in the Terrestrial Ecosystem Model.

\begin{tabular}{|c|c|c|}
\hline Acronym & Definition & Units \\
\hline \multicolumn{3}{|l|}{ State variables } \\
\hline $\mathrm{C}_{S}$ & $\mathrm{C}$ in soil and detritus & $\mathrm{g} / \mathrm{m}^{2}$ \\
\hline $\mathrm{C}_{V}$ & $C$ in vegetation & $\mathrm{g} / \mathrm{m}^{2}$ \\
\hline $\mathbf{N}_{\mathrm{av}}$ & Available inorganic $\mathrm{N}$ in soil and detritus & $\mathrm{g} / \mathrm{m}^{2}$ \\
\hline $\mathbf{N}_{s}$ & Organic $\mathrm{N}$ in soil and detritus & $\mathrm{g} / \mathrm{m}^{2}$ \\
\hline $\mathrm{N}_{V}$ & $\mathrm{~N}$ in vegetation & $\mathrm{g} / \mathrm{m}^{2}$ \\
\hline \multicolumn{3}{|l|}{ Carbon fluxes } \\
\hline GPP & Gross primary productivity & $\mathrm{g} \cdot \mathrm{m}^{-2} \cdot \mathrm{mo}^{-1}$ \\
\hline$L_{\mathrm{C}}$ & $\mathrm{C}$ in litterfall, above- and belowground & $\mathrm{g} \cdot \mathrm{m}^{-2} \cdot \mathrm{mo}^{-1}$ \\
\hline NEP & Net ecosystem productivity & $\mathrm{g} \cdot \mathrm{m}^{-2} \cdot \mathrm{mo}^{-1}$ \\
\hline NPP & Net primary productivity & $\mathrm{g} \cdot \mathrm{m}^{-2} \cdot \mathrm{mo}^{-1}$ \\
\hline$R_{A}$ & Autotrophic respiration & $\mathrm{g} \cdot \mathrm{m}^{-2} \cdot \mathrm{mo}^{-1}$ \\
\hline$R_{g}$ & Growth respiration & $\mathrm{g} \cdot \mathrm{m}^{-2} \cdot \mathrm{mo}^{-1}$ \\
\hline$R_{H}^{g}$ & Heterotrophic respiration (decomposition) & $\mathrm{g} \cdot \mathrm{m}^{-2} \cdot \mathrm{mo}^{-1}$ \\
\hline$R_{m}$ & Maintenance respiration & $\mathrm{g} \cdot \mathrm{m}^{-2} \cdot \mathrm{mo}^{-1}$ \\
\hline \multicolumn{3}{|l|}{ Nitrogen fluxes } \\
\hline$L_{\mathrm{N}}$ & $\mathrm{N}$ in litterfall, above- and belowground & $\mathrm{g} \cdot \mathrm{m}^{-2} \cdot \mathrm{mo}^{-1}$ \\
\hline NETNMIN & Net rate of mineralization of $\mathrm{N}_{S}$ & $\mathrm{~g} \cdot \mathrm{m}^{-2} \cdot \mathrm{mo}^{-1}$ \\
\hline NINPUT & $\mathrm{N}$ inputs from outside ecosystem & $\mathrm{g} \cdot \mathrm{m}^{-2} \cdot \mathrm{mo}^{-1}$ \\
\hline NLOST & $\mathrm{N}$ losses from ecosystem & $\mathrm{g} \cdot \mathrm{m}^{-2} \cdot \mathrm{mo}^{-1}$ \\
\hline NUPTAKE & $\mathrm{N}$ uptake by vegetation & $\mathrm{g} \cdot \mathrm{m}^{-2} \cdot \mathrm{mo}^{-1}$ \\
\hline \multicolumn{3}{|l|}{ Parameters } \\
\hline Ac & Relative amount of effort allocated to $\mathrm{C}$ vs. $\mathrm{N}$ uptake & None \\
\hline ADAPT & Rate of adaptation of vegetation & $\mathrm{mo}^{-1}$ \\
\hline $\mathrm{C}_{i}$ & $\mathrm{CO}_{2}$ concentration inside leaves & $\mu \mathrm{L} / \mathrm{L}$ \\
\hline $\mathrm{C}_{a}$ & Atmospheric $\mathrm{CO}_{2}$ concentration & $\mu \mathrm{L} / \mathrm{L}$ \\
\hline$C_{\max }$ & Maximum rate of photosynthesis $\mathrm{C}$ & $\mathrm{g} \cdot \mathrm{m}^{-2} \cdot \mathrm{mo}^{-1}$ \\
\hline$D$ & Mean state of decay of $C_{S}$ & $\mathrm{~g} / \mathrm{g}$ \\
\hline FC & Field capacity $(=$ soil moisture content at $-0.03 \mathrm{MPa})$ & $\%$ saturation \\
\hline$G_{V}$ & Relative conductance of the vegetation to $\mathrm{CO}_{2}$ uptake & None \\
\hline$k_{c}$ & Half-saturation constant for $\mathrm{CO}_{2}-\mathrm{C}$ uptake by plants & $\mu \mathrm{L} / \mathrm{L}$ \\
\hline$K_{d}$ & Heterotrophic respiration rate* at $0^{\circ} \mathrm{C}$ & $\mathrm{g} \cdot \mathrm{g}^{-1} \cdot \mathrm{mo}^{-1}$ \\
\hline KFALL & Proportion of $C_{V}$ lost as $L_{C}$ monthly & $\mathrm{g} \cdot \mathrm{g}^{-1} \cdot \mathrm{mo}^{-1}$ \\
\hline & Half-saturation constant for PAR use by plants $\dagger$ & $\mathrm{J} \cdot \mathrm{cm}^{-2} \cdot \mathrm{d}^{-1}$ \\
\hline KLEAF & Relative photosynthetic capacity of vegetation & None \\
\hline$k_{n 1}$ & Half-saturation constant for $\mathrm{N}$ uptake by vegetation & $\mathrm{g} / \mathrm{m}^{3}$ \\
\hline$k_{n 2}$ & Half-saturation constant for $\mathrm{N}$ uptake by heterotrophic organisms & $\mathrm{g} / \mathrm{m}^{3}$ \\
\hline$K_{r}$ & Plant respiration rate* at $0^{\circ} \mathrm{C}$ & $\mathrm{g} \cdot \mathrm{g}^{-1} \cdot \mathrm{mo}^{-1}$ \\
\hline$K_{s}$ & Relative difference in the conductance of the soil to $\mathrm{N}$ diffusion & None \\
\hline$L_{\mathrm{NC}}$ & Mean $\mathrm{N}: \mathrm{C}$ ratio of litterfall & $g / g$ \\
\hline$m 1$ & Parameter defining skewness of the normal curve in Eq. 14a & None \\
\hline$M_{\mathrm{opt}}$ & Optimum soil moisture content for $\mathrm{R}_{H}$ & $\%$ saturation \\
\hline$M_{\text {sat }}^{\text {opt }}$ & $\begin{array}{l}\text { Parameter defining the decomposition rate under saturated conditions in } \\
\text { Eq. 14b }\end{array}$ & None \\
\hline NLOSS & Proportional loss of $\mathrm{N}_{\mathrm{av}}$ from ecosystem & $\mathrm{g} \cdot \mathrm{g}^{-1} \cdot \mathrm{mo}^{-1}$ \\
\hline$N_{\max }$ & Maximum rate of $\mathrm{N}$ uptake by vegetation & $\mathrm{g} \cdot \mathrm{m}^{-2} \cdot \mathrm{mo}^{-1}$ \\
\hline$N_{\text {up }}$ & Ratio between $\mathrm{N}$ immobilized and $\mathrm{C}$ respired by heterotrophs & $\mathrm{g} / \mathrm{g}$ \\
\hline$T_{\max }^{\text {up }}$ & Maximum temperature for GPP & ${ }^{8} \mathrm{C}$ \\
\hline$T_{\min }^{\max }$ & Minimum temperature for GPP & ${ }^{\circ} \mathrm{C}$ \\
\hline$T_{\mathrm{opt}}$ & Optimum temperature for GPP & ${ }^{\circ} \mathrm{C}$ \\
\hline$V_{\mathrm{CN}}$ & Mean $\mathrm{C}: \mathrm{N}$ of vegetation & $g / g$ \\
\hline
\end{tabular}

* Respiration is measured as mass of carbon burned per unit mass of tissue carbon.

$\dagger 1 \mathrm{cal}=4.184 \mathrm{~J}$ exactly.

tually constant from year to year (i.e., for $100 \mathrm{yr}$ ). The state variables do change from month to month according to differential inputs and losses driven by seasonal changes in climate:

$$
\begin{aligned}
\frac{d \mathrm{C}_{V}}{d t} & =\mathrm{GPP}_{t}-\mathrm{R}_{A t}-\mathrm{L}_{C t} \\
\frac{d \mathrm{~N}_{V}}{d t} & =\mathrm{NUPTAKE}_{t}-\mathrm{L}_{N t} \\
\frac{d \mathrm{C}_{S}}{d t} & =\mathrm{L}_{C t}-\mathrm{R}_{H t}
\end{aligned}
$$

$$
\begin{aligned}
\frac{d \mathrm{~N}_{S}}{d t}= & \mathrm{L}_{N t}-\mathrm{NETNMIN}_{t} \\
\frac{d \mathrm{~N}_{\mathrm{av}}}{d t}= & \text { NINPUT }_{t}+\text { NETNMIN }_{t}-\text { NLOST }_{t} \\
& - \text { NUPTAKE }_{t},
\end{aligned}
$$

where $t$ refers to the time step of the calculation (generally one month) and all acronyms are as defined in Table A1. We used a variable time step, 5th-6th order Runga-Kutta integration procedure (Cheney and Kincaid 1985) to assure sta- 
TABLE A2. Values of constant parameters used in the Terrestrial Ecosystem Model. Parameters are defined in Table A1.

\begin{tabular}{lc}
\hline \hline Parameter & Value \\
\hline ADAPT & $0.001 \mathrm{mo}^{-1}$ \\
$k_{c}$ & $200 \mu \mathrm{L} / \mathrm{L}$ \\
$k_{i}$ & $314 \mathrm{~J} \cdot \mathrm{cm}^{-2} \cdot \mathrm{d}^{-1}$ \\
$k_{n 1}$ & $1.0 \mathrm{~g} / \mathrm{m}^{3}$ \\
$k_{n 2}$ & $1.0 \mathrm{~g} / \mathrm{m}^{3}$ \\
\hline
\end{tabular}

bility in the integrations over time. Units for all state variables are grams per square metre of either $\mathrm{C}$ or $\mathrm{N}$, and units for all element fluxes are grams per square metre per month. Each of the fluxes included in Eqs. 1.1 through 1.5, and how it is controlled by external environmental variables, is described in detail below. All acronyms and parameters utilized in TEM are defined in Table A1, and all parameter values used in the model applications discussed in the main text are shown in Tables A2 to A5.

\section{Carbon fluxes}

Gross primary productivity (GPP) is defined in TEM as the total assimilation of $\mathrm{CO}_{2}-\mathrm{C}$ by plants, excluding photorespiration. There are few existing measurements of the GPP of whole plant communities, so our estimates are based upon available information on net primary productivity and wholeplant respiration rates. GPP is modeled as a function of the irradiance of photosynthetically active radiation (PAR), atmospheric $\mathrm{CO}_{2}$ concentrations, moisture availability, mean air temperature, the relative photosynthetic capacity of the vegetation, and, indirectly, nitrogen availability. For each time step:

$$
\mathrm{GPP}=\left(\mathrm{C}_{\max }\right) \frac{\mathrm{PAR}}{k_{i}+\mathrm{PAR}} \frac{\mathrm{C}_{i}}{k_{c}+\mathrm{C}_{i}}(\mathrm{TEMP})(\mathrm{Ac})
$$

$\cdot($ KLEAF),

where $\mathrm{C}_{\max }$ is the maximum rate of $\mathrm{C}$ assimilation by the entire plant canopy under optimal environmental conditions (in grams per square metre per month); PAR is the irradiance of photosynthetically active radiation at canopy level (in joules per square centimetre per day); $k_{i}$ is the irradiance at which $\mathrm{C}$ assimilation proceeds at one-half its maximum rate; $\mathrm{C}_{i}$ is the concentration of $\mathrm{CO}_{2}$ inside leaves (in microlitres per litre); $k_{c}$ is the internal $\mathrm{CO}_{2}$ concentration at which $\mathrm{C}$ assimilation proceeds at one-half its maximum rate; and TEMP, Ac, and KLEAF are unitless multipliers expressing the influences of air temperature, relative nutrient availability, and plant phenology, respectively, on GPP. The value of $C_{\max }$ was defined for each vegetation type by adjusting its value during calibration of the model until predicted annual NPP matched the literature-based NPP estimate for the calibration site.

Increasing irradiance of PAR increases GPP hyperbolically, as has been demonstrated in a number of leaf studies (e.g., Larcher 1980). The shape of this hyperbolic function is defined by PAR and the half-saturation constant $k_{i}$ (Fig. A1 A). We estimated a mean value of $314 \mathrm{~J} \cdot \mathrm{cm}^{-2} \cdot \mathrm{d}^{-1}$ for $k_{i}$ from published leaf studies, and assume that this value applies to entire leaf canopies independent of vegetation type. We did not investigate the sensitivity of TEM to this parameter.

The influence of increasing atmospheric concentrations of $\mathrm{CO}_{2}$ on GPP is assumed to follow Michaelis-Menten kinetics (Fig. A1 B). We assume that $\mathrm{CO}_{2}$ concentrations inside leaves $\left(\mathrm{C}_{i}\right)$ are directly proportional to atmospheric $\mathrm{CO}_{2}$ concentrations $\left(\mathrm{C}_{a}\right)$ when stomata are fully open, as demonstrated by Wong et al. (1979). Although $C_{i}$ is typically less than $C_{a}$ we assume them to be equal when moisture is not limiting. This
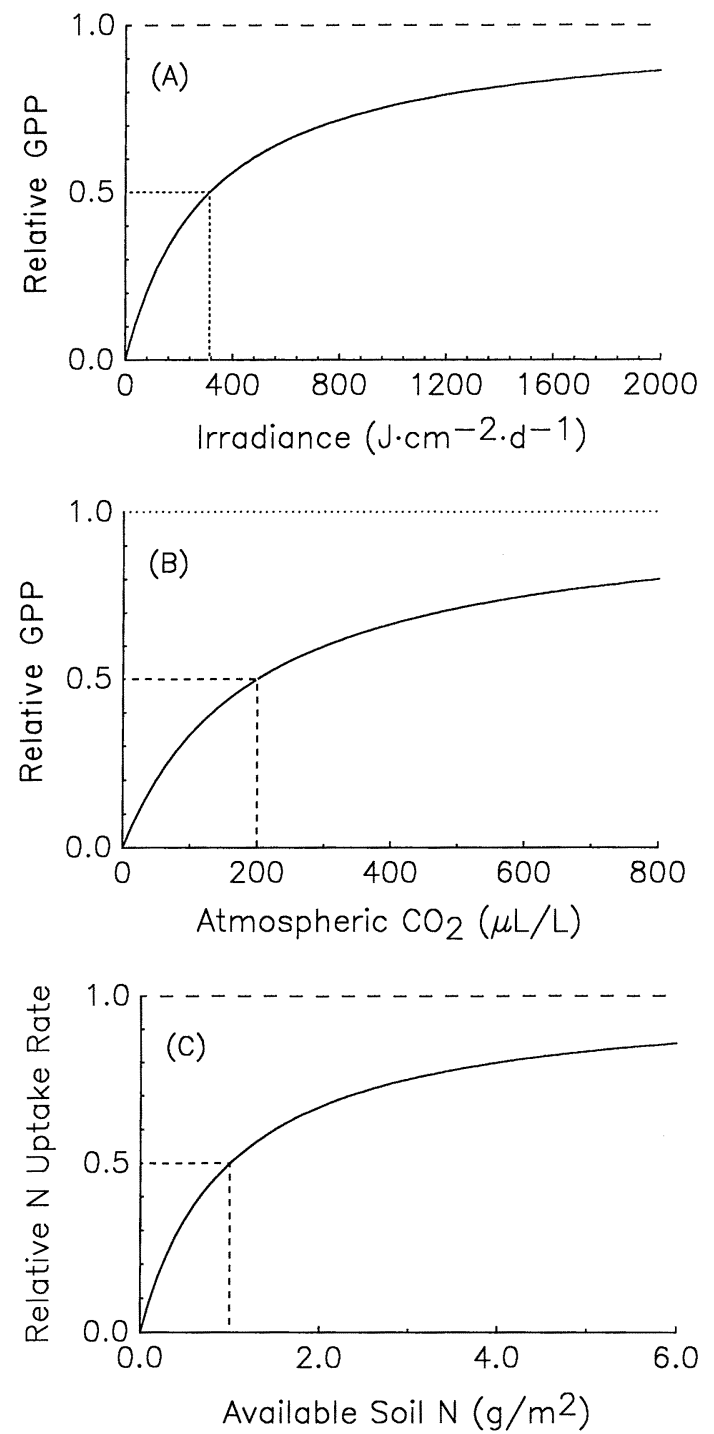

Fig. A1. Hyperbolic relationships defined for the prediction of gross primary productivity (GPP) and nitrogen uptake by vegetation. Vertical dashed lines show the locations of the presumed half-saturation values of the independent variables. (A) Relationship between GPP and the irradiance of photosynthetically active radiation, all other factors being optimal. This relationship is applied to the entire leaf canopy, not to individual leaves within the ecosystem. (B) Relationship between GPP and the atmospheric $\mathrm{CO}_{2}$ concentration, all other factors being optimal. As in (A), this relationship applies to the entire leaf canopy. All results presented in this paper are based on an atmospheric $\mathrm{CO}_{2}$ concentration of $340 \mu \mathrm{L} / \mathrm{L}$. (C) Relationship between the rate of nitrogen uptake by vegetation and the quantity of available soil inorganic nitrogen, all other factors being optimal.

Half-saturation values were estimated from published studies and are assumed to be constant, irrespective of vegetation type. Values of the asymptotes were defined by model calibration for each of the seven vegetation types in South America. 


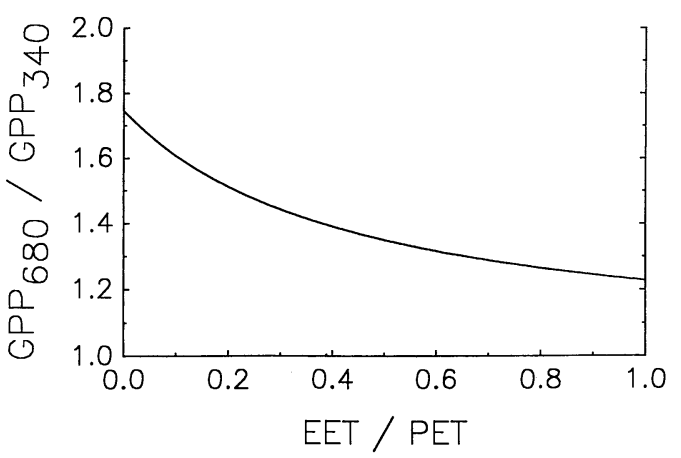

FIG. A2. The relative influence of a doubling of atmospheric $\mathrm{CO}_{2}$ concentrations on gross primary productivity (GPP) along a moisture availability gradient, assuming all other factors remain constant and optimal. The dependent axis shows the estimated GPP at a $\mathrm{CO}_{2}$ level of $680 \mu \mathrm{L} / \mathrm{L}$ divided by that at a $\mathrm{CO}_{2}$ level of $340 \mu \mathrm{L} / \mathrm{L}$. Moisture availability is expressed as the ratio between estimated actual evapotranspiration and potential evapotranspiration (EET/ PET).

does not affect the equilibrium results discussed in this paper, but further refinement of this relationship will be required before investigating the effects of increasing atmospheric $\mathrm{CO}_{2}$ concentrations.

Available information from $\mathrm{CO}_{2}$-enrichment studies indicates that plant yields increase $24-50 \%$ with a doubling of atmospheric $\mathrm{CO}_{2}$, given adequate nutrients and water (Kimball 1975, Gates 1985). Assuming a low value of $23 \%$, the half-saturation constant $k_{c}$ was defined to be $200 \mu \mathrm{L} / \mathrm{L}$. For model runs discussed in this paper, atmospheric $\mathrm{CO}_{2}$ was assumed to be a constant $340 \mu \mathrm{L} / \mathrm{L}$. Our selection of a constant value for $k_{c}$ therefore has no influence on the results discussed herein.

Moisture limitations diminish $\mathrm{CO}_{2}$ assimilation by modifying the conductance of leaves to $\mathrm{CO}_{2}$ diffusion, and by directly modifying the biochemistry of photosynthesis (Kramer
1983). We consider only the first of these processes in TEM. Our best estimate of mean monthly moisture availability is the degree to which environmental demands for water are met by rainfall and available soil moisture, this relationship being expressed as the ratio of estimated actual evapotranspiration (EET) to potential evapotranspiration (PET). In TEM we assume that the relationship between $\mathrm{CO}_{2}$ concentrations inside stomatal cavities $\left(C_{i}\right)$ and in the atmosphere $\left(C_{a}\right)$ is directly proportional to relative moisture availability:

$$
G_{V}=0.10+(0.9 \mathrm{EET} / \mathrm{PET})
$$

and

$$
\mathrm{C}_{i}=G_{V} \mathrm{C}_{a},
$$

where $G_{V}$ is a unitless multiplier that accounts for changes in leaf conductivity to $\mathrm{CO}_{2}$ resulting from changes in moisture availability. The $y$-intercept of Eq. 1.7a is assumed to be $>$ 0 to account for within-grid-cell heterogeneity in moisture availability. Decreasing moisture availability is assumed to increase stomatal closure, thereby decreasing the internal $\mathrm{CO}_{2}$ concentrations. This relationship is based on the tight correlation found between transpiration rates and $\mathrm{CO}_{2}$ assimilation (Chang 1968, Kramer 1983). An alternative model describing the influence of stomatal conductance on $\mathrm{C}$ assimilation is presented by Lommen et al. (1971), but difficulties in defining actual values of total canopy resistance to $\mathrm{CO}_{2}$ uptake preclude its use.

Atmospheric $\mathrm{CO}_{2}$ concentrations and moisture availability have interactive effects on potential GPP. The TEM predicts that doubling atmospheric $\mathrm{CO}_{2}$ concentrations will result in larger increases in production when moisture stress is high than when moisture stress is low (Fig. A2). This is consistent with empirical data (e.g., Gates 1985, Idso 1988).

Moisture stress also influences the phenology of vegetation, causing, for instance, leaf shedding. This latter factor is included in our phenology model, discussed below, and further depresses GPP during dry seasons.

Temperature effects on GPP are assumed to be the same as measured temperature effects on net primary productivity. We utilized the information in Larcher (1980) to define optimum $\left(T_{\mathrm{opt}}\right)$, minimum $\left(T_{\mathrm{min}}\right)$, and maximum temperatures $\left(T_{\max }\right)$ for photosynthesis for each type of vegetation in South

TABLE A3. Values of vegetation-specific parameters used in the Terrestrial Ecosystem Model. Site locations are shown in Table 1 . The values of $T_{\min }, T_{\mathrm{opt}}$, and $T_{\max }$ were defined from the information compiled by Larcher (1980). Values of the

\begin{tabular}{|c|c|c|c|c|c|c|c|c|c|c|c|c|}
\hline Site & $\begin{array}{l}\text { Vegetation } \\
\text { type }\end{array}$ & $C_{\max }$ & $K_{d}$ & KFALL & $K_{r}$ & $L_{\mathrm{NC}}$ & $N_{\max }$ & $N_{\text {up }}$ & $T_{\min }$ & $T_{\mathrm{opt}}$ & $T_{\max }$ & $V_{\mathrm{CN}}$ \\
\hline$\overline{\text { Osage }}$ & Grassland & 924.7 & .000964 & .063003 & .016 & .01170 & 0.38300 & -.13735 & 1.0 & 30.0 & 48.0 & 113.0 \\
\hline Nylsvley & Savanna & 902.0 & .006065 & .024829 & .008 & .02 & 4.92000 & -.31505 & -1.0 & 30.0 & 49.5 & 57.3 \\
\hline Nacuñan & $\begin{array}{l}\text { Arid } \\
\text { shrubland }\end{array}$ & 251.2 & .004330 & .013572 & .008 & .02714 & 0.41870 & -.34971 & -3.0 & 25.0 & 48.5 & 35.8 \\
\hline Chakia & $\begin{array}{l}\text { Deciduous } \\
\text { forest }\end{array}$ & 2598.4 & .002682 & .005276 & .004 & .03858 & 1.96670 & -.28145 & 0.0 & 26.0 & 48.0 & 66.4 \\
\hline Guanica & $\begin{array}{l}\text { Xeromor- } \\
\text { phic forest }\end{array}$ & 963.9 & .001920 & .010902 & .004 & .02530 & 0.81032 & -.11935 & -1.5 & 25.5 & 48.5 & 46.6 \\
\hline Taita & $\begin{array}{l}\text { Temperate } \\
\text { forest }\end{array}$ & 1303.1 & .002098 & .004033 & .004 & .00826 & 0.86245 & -.06807 & -2.0 & 22.5 & 44.0 & 357.0 \\
\hline Banco & $\begin{array}{l}\text { Evergreen } \\
\text { forest }\end{array}$ & 3823.2 & .001441 & .004276 & .004 & .02627 & 2.55960 & -.05950 & 2.5 & 27.5 & 47.5 & 173.0 \\
\hline Ducke & $\begin{array}{l}\text { Evergreen } \\
\text { forest }\end{array}$ & 3167.3 & .001080 & .003931 & .004 & .02262 & 1.66965 & -.12860 & 2.5 & 27.5 & 47.5 & 75.4 \\
\hline El Verde & $\begin{array}{l}\text { Evergreen } \\
\text { forest }\end{array}$ & 1883.0 & .001969 & .006667 & .004 & .02404 & 1.36565 & -.21280 & 2.5 & 27.5 & 47.5 & 105.7 \\
\hline Kade & $\begin{array}{l}\text { Evergreen } \\
\text { forest }\end{array}$ & 2198.3 & .002136 & .007031 & .004 & .02869 & 2.12510 & -.13744 & 2.5 & 27.5 & 47.5 & 75.7 \\
\hline Pasoh & $\begin{array}{c}\text { Evergreen } \\
\text { forest }\end{array}$ & 4484.2 & .002002 & .004206 & .004 & .01847 & 1.23810 & -.15320 & 2.5 & 27.5 & 47.5 & 161.0 \\
\hline $\begin{array}{l}\text { San } \\
\text { Carlos }\end{array}$ & $\begin{array}{l}\text { Evergreen } \\
\text { forest }\end{array}$ & 2421.1 & .001614 & .007226 & .004 & .02178 & 1.20812 & -.03278 & 2.5 & 27.5 & 47.5 & 95.3 \\
\hline
\end{tabular}
other parameters were determined by calibration of the model. Parameters are defined in Table A1. 


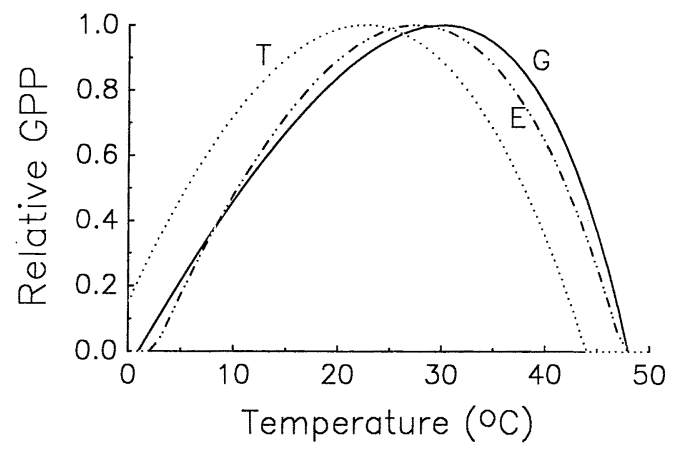

FIG. A3. The effect of mean monthly air temperatures on estimated gross primary productivity (GPP) for tropical evergreen forests $(E)$, grasslands $(G)$, and temperate forests $(T)$. The dependent variable is used as a simple multiplier on estimated GPP. Specific curves have been defined for each of the seven vegetation types in South America. Three of them are shown here.

America (Table A3). We model the temperature effect as a simple multiplier on potential GPP, with a maximum value of 1.0 (i.e., no effect) at the optimum temperature and lower values at all suboptimal temperatures (Fig. A3). For each time step:

$$
\text { TEMP }=\frac{\left(T-T_{\min }\right)\left(T-T_{\max }\right)}{\left[\left(T-T_{\min }\right)\left(T-T_{\max }\right)\right]-\left(T-T_{\mathrm{opt}}\right)^{2}},
$$

where TEMP is the temperature multiplier on GPP (no units) and $T$ is the mean monthly air temperature $\left({ }^{\circ} \mathrm{C}\right)$. Values of TEMP estimated by Eq. 1.8 are limited to a minimum of zero.

Nitrogen availability influences GPP indirectly by influencing the relative allocation of effort toward $\mathrm{C}$ vs. $\mathrm{N}$ uptake (Ac), as defined by our allocation submodel. This is described in detail below (see Carbon-nitrogen interactions).

Phenological processes involved with leaf initiation and retention, enzymatic activity levels, and other processes that alter the ability of plants to utilize atmospheric $\mathrm{CO}_{2}$ alter the rate at which photosynthesis proceeds, independently of the environmental relationships considered so far. We developed a separate phenological model that describes seasonal changes in the vegetation's capacity to assimilate C. This model simulates relative changes in the photosynthetic capacity of mature vegetation (KLEAF) from estimated actual evapotranspiration (EET) and the previous month's photosynthetic capacity:

$$
\begin{aligned}
\mathrm{KLEAF}_{j} & =a\left(\mathrm{EET}_{j} / \mathrm{EET}_{\text {max }}\right)+b\left(\mathrm{KLEAF}_{j-1}\right)+c \\
\mathrm{KLEAF}_{j} & =1.0 \quad \text { if } \mathrm{KLEAF}_{j}>1.0 \\
\mathrm{KLEAF}_{j} & =\mathrm{KLEAF}_{t} / \mathrm{KLEAF}_{\text {max }} \\
& \quad \text { if } \mathrm{KLEAF}_{\text {max }}<1.0 \\
\mathrm{KLEAF}_{j} & =\text { min } \quad \text { if } \mathrm{KLEAF}_{j}<\min .
\end{aligned}
$$

Here, the time step $\mathrm{j}$ is one month; $\mathrm{EET}_{\max }$ is the maximum EET occurring during any month in that location; $a, b$, and $c$ are regression-derived parameters; $\min$ is a pre-established value below which the relative photosynthetic capacity is not allowed to go (Table A4), and $\mathrm{KLEAF}_{\max }$ refers to the maximum predicted KLEAF from Eq. 1.9a for a specific location. Eqs. $1.9 \mathrm{~b}$ through $1.9 \mathrm{~d}$ normalize the predictions from Eq. $1.9 \mathrm{a}$ to a maximum of 1.0 and a minimum value defined by the parameter "min." Values of KLEAF as predicted from Eqs. 1.9a-d have no units, and are used as multipliers in the production Eq. 6.
Plant (autotrophic) respiration $\left(R_{A}\right)$ is the total respiration (excluding photorespiration) of living vegetation, including all $\mathrm{CO}_{2}$ production from the various processes of plant maintenance, nutrient uptake, and biomass construction. In TEM, $R_{A}$ is the sum of maintenance respiration, $R_{m}$, and growth respiration, $R_{g}$ :

$$
R_{A}=R_{m}+R_{g}
$$

We model maintenance respiration as a direct function of plant biomass $\left(C_{V}\right)$, and assume that increasing temperatures increase maintenance respiration rates logarithmically with a $Q_{10}$ of 2.0 over all temperatures:

$$
R_{m}=K_{r}\left(\mathrm{C}_{V}\right) e^{0.0693 T},
$$

where $K_{r}$ is the respiration (carbon loss) rate of the vegetation per unit of biomass carbon at $0^{\circ} \mathrm{C}$ in grams per gram per month, and $T$ is the mean monthly air temperature in degrees Celsius (Fig. A4). There is virtually no information available on whole-plant respiration rates in most ecosystems. We therefore determined values of $K_{r}$ by calibrating TEM in such a way that estimated total plant respiration $\left(R_{A}\right)$ correctly matched the estimates of total autotrophic respiration for an oak-pine forest in New York (Woodwell and Botkin 1970), a Liriodendron forest in Tennessee (Harris et al. 1975), and a tallgrass prairie in Oklahoma (Risser et al. 1981). We applied the mean $K_{r}$ value derived from the two forested sites to all forests, the single grassland value to all grasslands, and a midway value to savannas, woodlands, and shrublands (Fig. A4).

Growth or construction respiration $\left(R_{g}\right)$ is estimated to be $20 \%$ of the difference between GPP and $R_{m}$ :

$$
\begin{aligned}
\mathrm{NPP}_{t} & =\mathrm{GPP}_{t}-R_{m t} \\
R_{g t} & =0.2 \mathrm{NPP}_{t}{ }_{t} \quad \text { if } \mathrm{NPP}_{t}{ }_{t}>0.0 \\
R_{g t} & =0.0 \quad \text { if } \mathrm{NPP}_{t}{ }_{t} \leq 0.0,
\end{aligned}
$$

where NPP' is the potential net primary production assuming that the conversion efficiency of photosynthate to biomass is $100 \%$ and $t$ refers to the time step of the calculation. The assumption that $20 \%$ of the available photosynthate is respired during construction of new biomass (Eq. 1.10d) is an estimated mean ecosystem value based on the works of Chung and Barnes (1977), Vertregt and Penning de Vries (1987), and Williams et al. (1987) (see also Ryan 1991). Respiration resulting from nutrient uptake is assumed to be part of $R_{m}$

$N P P$. The prediction of potential net primary productivity (NPP) is a principal objective of TEM, and so deserves particular attention. Net primary productivity is defined as the

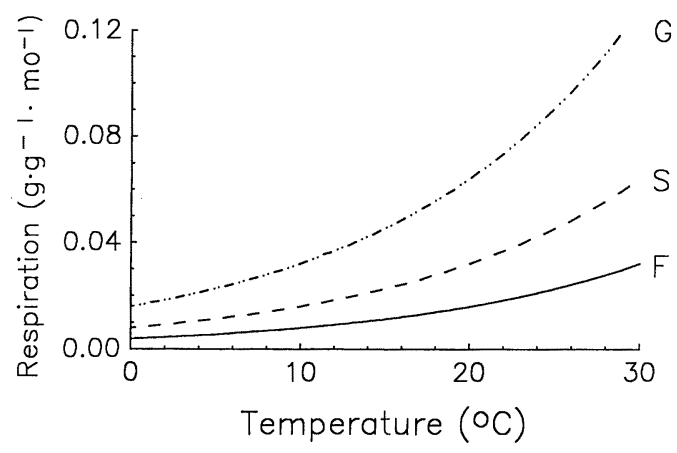

FIG. A4. Relationship between mean monthly air temperatures and the biomass-specific respiration (carbon combustion) rate of live vegetation in grassland $(\mathrm{G})$, savanna $(\mathrm{S})$, and forest $(\mathrm{F})$ ecosystems. In each case respiration rates increase with a $Q_{10}$ of 2.0 over all temperatures. 
TABLE A4. Values of parameters used to estimate the relative photosynthetic capacity of the vegetation (KLEAF) in Eqs. $1.9 \mathrm{a}-\mathrm{d}$. Values of KLEAF are constrained to a maximum of 1.0 , and to a minimum defined by the parameter "min." The parameters $a, b$, and $c$ were defined from multiple regression analysis of published data from a variety of sources; min was estimated from these same data. Tropical evergreen and temperate forests were assumed to have a complete leaf canopy throughout the year.

\begin{tabular}{lllll}
\hline \hline & \multicolumn{3}{c}{ Parameter } \\
\cline { 2 - 5 } \multicolumn{1}{c}{ Vegetation type } & \multicolumn{1}{c}{$a$} & $b$ & $c$ & $\mathrm{~min}$ \\
\hline Tropical evergreen forest & 0.0 & 0.0 & 1.00 & 1.00 \\
Tropical deciduous forest & 0.3230 & 0.7295 & 0.01275 & 0.26 \\
Temperate forest & 0.0 & 0.0 & 1.00 & 1.00 \\
Savanna & 0.3492 & 0.7274 & -0.04567 & 0.14 \\
Xeromorphic forest & 0.3230 & 0.7295 & 0.01275 & 0.26 \\
Grassland & 0.4863 & 0.4948 & -0.03786 & 0.06 \\
Arid shrubland & 0.2706 & 0.7462 & 0.01737 & 0.30 \\
\hline
\end{tabular}

difference between gross primary productivity and autotrophic respiration:

$$
\mathrm{NPP}_{t}=\mathrm{GPP}_{t}-R_{A t}
$$

where $t$ refers to the time step of the calculation. Monthly estimates of ecosystem NPP do not exist for most vegetation types, so the model was calibrated to correctly estimate annual NPP as defined by field studies. Predictions made by TEM are therefore more highly resolved temporally than are the input data. Estimates of annual NPP used to calibrate TEM are derived directly from site-specific field studies reported in the literature. Unfortunately, specific components of NPP are sometimes ignored; this is particularly true of belowground production and biomass losses to herbivory. We established the following rules for determining NPP from commonly measured fluxes:

1) We make no adjustment for unmeasured losses to herbivores and therefore underestimate NPP.

2) Lacking direct information we estimate belowground production in forests from litterfall data using:

$$
\begin{aligned}
\text { LRP }= & (\text { Woody root biomass/Stemwood biomass }) \\
& \times(\text { Stemwood NPP }) \\
\text { FRP }= & 0.5 \times(\text { Soil respiration }- \text { Litterfall })
\end{aligned}
$$

or, lacking information on soil respiration:

$$
\text { FRP }=\text { litterfall, }
$$

where LRP = large root production, FRP = net fine root production, and Stemwood NPP = annual aboveground wood production, all expressed as grams of $\mathrm{C}$ per square metre per year. The first relationship is derived from Newbould (1968), but includes only woody tissues. The second equation is derived from an analysis of soil carbon budgets (Raich and Nadelhoffer 1989). The final equation is an approximation that provides an estimate consistent with $\mathrm{C}$ - and N-budget techniques for estimating FRP (Nadelhoffer and Raich 1992). In non-forested ecosystems published estimates of belowground NPP were used (Appendix 2).

3) We use litterfall measurements to estimate leaf and branch production without correcting for decomposition losses prior to litter collection. This will lead to an underestimate of NPP in warm, humid environments such as those in the Amazon Basin.

4) We do not use estimates of NPP that are determined solely from statistical correlations between NPP and environmental parameters such as actual evapotranspiration (AET) or rainfall.

5) We attempt to be certain that the literature-based NPP estimates we use include all important components of NPP (e.g., fine-root production), and estimate missing data as needed.

The specific NPP values used to calibrate TEM and their sources are given in Appendix 2. The seasonality of NPP as defined by Eq. 1.11 may vary from observed seasonal changes in vegetation because TEM determines NPP when it occurs, not when growth from stored reserves occurs.

Carbon in litter production $\left(L_{\mathrm{C}}\right)$ is the total production of organic detritus by living vegetation, both above- and belowground, including all $\mathrm{C}$ losses in abscissed tissues, plant mortality, exudates, leachates, and herbivory. In the current version of TEM annual litter production is assumed equal to annual NPP. We model litter production $\left(L_{C}\right)$ as a direct function of plant biomass $\left(\mathrm{C}_{V}\right)$ :

$$
\begin{aligned}
\text { KFALL } & =\frac{(\text { annual NPP })}{12\left(\text { mean annual } \mathrm{C}_{V}\right)} \text { and } \\
L_{C t} & =C_{V t}(\mathrm{KFALL}) .
\end{aligned}
$$

Annual NPP and mean annual $C_{V}$ are defined from literature sources for the specific sites used to calibrate TEM (Appendix 2 ). The parameter KFALL is assumed to be constant within each vegetation type.

Heterotrophic respiration $\left(R_{H}\right)$ is the only loss of $\mathrm{C}$ from the detrital compartment $\left(\mathrm{C}_{S}\right)$. It is, in TEM, total C mineralization from detritus, and is therefore our estimate of total organic matter decomposition. Heterotrophic respiration is modelled as a function of soil $\mathrm{C}\left(\mathrm{C}_{S}\right)$, mean air temperature (T), mean soil moisture, and the gram-specific decomposition constant $K_{d}$. For each month:

$$
R_{H}=K_{d}\left(\mathrm{C}_{S}\right) e^{0.0693 T} \mathrm{MOIST} \text {. }
$$

As with plant maintenance respiration, we assume that increasing temperatures increase the heterotrophic respiration rate with a $Q_{10}$ of 2.0 over all temperatures. The value of $K_{d}$

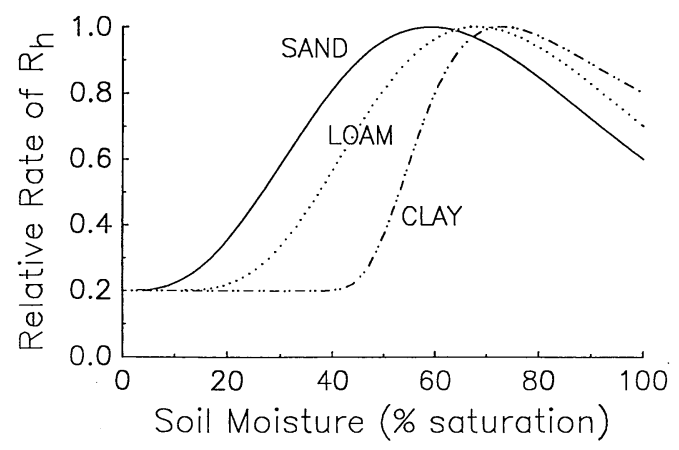

Fig. A5. Relationship between mean monthly soil moisture content and the rate of heterotrophic respiration $\left(R_{H}\right)$. Individual relationships are defined for each of five soil-texture classes; those for sandy loams and clay loams fall between the curves shown. Heterotrophic respiration is equivalent to decomposition in the Terrestrial Ecosystem Model (TEM). 
TABLE A5. Values of soil-specific parameters used in the Terrestrial Ecosystem Model. Parameters are defined in Table A1.

Five soil texture classes are included in TEM.

\begin{tabular}{lccccc}
\hline \hline & \multicolumn{5}{c}{ Texture class } \\
\cline { 2 - 6 } \multicolumn{1}{c}{ Parameter* } & \multicolumn{1}{c}{ Sand } & Sandy loam & Loam & Clay loam & Clay \\
\hline FC (\% H $\mathrm{H}_{2} \mathrm{O}$ saturation) & 39.0 & 48.5 & 58.1 & 68.4 & 88.7 \\
$M_{\text {opt }}$ (\% H $\mathrm{H}_{2} \mathrm{O}$ saturation) & 59.0 & 64.0 & 68.0 & 71.0 & 73.0 \\
$m 1$ & 0.356 & 0.308 & 0.140 & -0.624 & -1.883 \\
$M_{\text {sat }}$ & 0.5000 & 0.5625 & 0.6250 & 0.6875 & 0.7500 \\
\hline
\end{tabular}

* Field capacity (FC) was estimated from Saxton et al. (1986). Saturation occurs when $100 \%$ of the pore volume is full of water.

is determined by model calibration on a vegetation-specific basis.

MOIST is a function defining the influence of soil moisture on decomposition. Moisture is believed to influence decomposition via its influences on moisture availability at low soil-moisture contents and on oxygen availability at high moisture contents. We define these influences on a monthly basis from:

$$
\begin{aligned}
B & =\left[\frac{M^{m 1}-M_{\mathrm{opt}}^{m 1}}{M_{\mathrm{opt}}{ }^{m 1}-100^{m 1}}\right]^{2} \text { and } \\
\text { MOIST } & =\left(0.8 M_{\mathrm{sat}}^{B}\right)+0.2,
\end{aligned}
$$

where $M$ is mean monthly soil moisture (percentage of saturation), $m 1$ is a parameter defining the skewness of the curve, $M_{\text {opt }}$ is the soil moisture content at which $R_{H}$ is maximum (1.0), and $M_{\text {sat }}$ is a parameter that determines the value of MOIST when the soil pore space is saturated with water. In Eq. $1.14 \mathrm{~b}$ the values of MOIST are normalized to range from 0.2 to 1.0 without units. Different curves are defined for each of the five soil-texture classes considered (e.g., Fig. A5).

The specific relationships we defined between relative decomposition rate and soil moisture (Fig. A5) are based on the rule of thumb that maximum decomposition rates occur when soils are 50-80\% saturated with water (Clark 1967, Alexander 1977). In soils of different water-holding capacities this occurs when the soil volume is $\approx 15 \%$ air; this point defines our optimum for each soil type (Table A5). We also set the rate of decomposition at a soil moisture tension of $1.5 \mathrm{MPa}$ to be $30 \%$ of the maximum rate, and the decomposition rate at saturation to be $60-80 \%$ of its maximum rate. These values typify the approximate means of a variety of laboratory and field decomposition studies (Bartholomew and Norman 1946, Bhaumik and Clark 1947, Miller and Johnson 1964, Ino and Monsi 1969, Hunt 1977, Davidson 1979, Sommers et al. 1981, Van Veen and Paul 1981, Stott et al. 1986). Finally, we assume that the minimum relative decomposition rate with respect to soil moisture is 0.2 . This latter assumption is based in part on the effect of scaling soil moisture across large areas, but also indicates that decomposition may be little influenced by soil moisture under dry conditions (e.g., Whitford et al. 1988).

Net ecosystem productivity (NEP) is defined as the net rate of $\mathrm{C}$ accumulation by the ecosystem:

$$
\mathrm{NEP}=\mathrm{GPP}-R_{A}-R_{H} .
$$

Annual NEP is assumed to be zero under the equilibrium conditions discussed in this paper.

\section{Nitrogen fluxes}

Nitrogen uptake by vegetation (NUPTAKE) represents the total uptake of $\mathrm{N}$ from the soil by vegetation. In TEM, all uptake is assumed to be from the available $\mathrm{N}$ pool (nitrate, nitrite, and ammonium). It does not include $\mathrm{N}$ fixation by symbiotic organisms, which is considered an input to the available soil $\mathrm{N}$ pool. NUPTAKE is modelled as a function of available soil $\mathrm{N}\left(\mathrm{N}_{\mathrm{av}}\right)$, soil moisture, mean air temperature, and the relative amount of energy allocated to $\mathrm{N}$ versus $\mathrm{C}$ uptake:

$$
\text { NUPTAKE }=\left[\frac{\mathrm{N}_{\max }\left(K_{s}\right) \mathrm{N}_{\mathrm{av}}}{k_{n 1}+\left(K_{s} \mathrm{~N}_{\mathrm{av}}\right)}\right] e^{0.0693 T}(1-\mathrm{Ac}),
$$

where $N_{\max }$ is the maximum rate of $\mathrm{N}$ uptake by the vegetation in grams per square metre per month, $K_{s}$ is a parameter accounting for relative differences in the conductance of the soil to $\mathrm{N}$ diffusion, $k_{n 1}$ is the concentration of $\mathrm{N}_{\mathrm{av}}$ at which $\mathrm{N}$ uptake proceeds at one-half its maximum rate, $T$ is the mean monthly air temperature, and Ac is the relative allocation of effort devoted to $\mathrm{C}$ assimilation. The parameter Ac is discussed below (see Carbon-nitrogen interactions). Because $\mathrm{N}$ uptake is an active process requiring metabolic energy (Clarkson 1985), we utilize the same temperature-dependent function in Eq. 1.16 that is used to model $R_{A}$ and $R_{H}$.

We follow many others in utilizing Michaelis-Menten kinetics to model $\mathrm{N}$ uptake by plants (e.g., Nye and Tinker 1977, Clarkson 1985, Haynes 1986). Published values of halfsaturation constants for plant uptake of inorganic $\mathrm{N}$ are exceedingly variable, ranging from 10 to $600 \mu \mathrm{mol} / \mathrm{L}$ (Nye and Tinker 1977, Haynes 1986). Correlation of these concentration values with field measurements of available soil $\mathrm{N}$ is difficult. We therefore selected a value for $k_{n 1}$ of $1 \mathrm{~g} / \mathrm{m}^{2}$ (Fig. $\mathrm{A} 1 \mathrm{C})$, which is the approximate amount of $\mathrm{N}$ present in most of the forest sites used to calibrate the model. As a result, NUPTAKE is approximately linearly related to $\mathrm{N}_{\mathrm{av}}$ in most of the calibration sites. We did not test the sensitivity of TEM to the value of $k_{n 1}$. The value of $N_{\max }$ is determined during calibration of the model so that annual $\mathrm{N}$ uptake (NUPTAKE) is equal to the annual $\mathrm{N}$ flux in litter production $\left(L_{\mathrm{N}}\right)$ for the calibration sites.

Soil moisture is assumed to influence $\mathrm{N}$ uptake via its influence on nutrient diffusion rates through the soil:

$$
K_{s}=0.90(M / F C)^{3}+0.10,
$$

where $M$ is the mean monthly soil moisture expressed as the percentage of saturation, FC is the soil moisture content at field capacity, and the parameter $K_{s}$ represents the influence of soil moisture conditions on $\mathrm{N}$ movement through the soil. This function is based on the observation that nutrient diffusion rates through soils are proportional to $\Theta^{3}$ (Papendick and Campbell 1981), $\Theta$ being the volumetric soil-moisture content in cubic centimetres of water per cubic centimetre of soil. Different soils have different water-holding capacities; by dividing $M$ by FC, we normalized these differences so that all soils have the same conductance at field capacity.

Nitrogen in litter production $\left(L_{\mathrm{N}}\right)$, the only flux of $\mathrm{N}$ from living vegetation in TEM, is defined as the total amount of $\mathrm{N}$ present in abscissed tissues, mortality, exudates, leachates, and herbivory, and is therefore directly analogous to litterfall $\mathrm{C}\left(L_{\mathrm{C}}\right)$. Under the equilibrium conditions discussed in this paper, $L_{\mathrm{N}}$ is equal on an annual basis to annual $\mathrm{N}$ uptake by the vegetation. We estimate $L_{\mathrm{N}}$ each month from: 


$$
L_{\mathrm{N}}=L_{\mathrm{C}}\left(\mathrm{N}_{V} / \mathrm{C}_{V}\right) V_{\mathrm{CN}} L_{\mathrm{NC}},
$$

where $L_{\mathrm{C}}$ is litterfall $\mathrm{C}, \mathrm{N}_{V}$ and $\mathrm{C}_{V}$ are the masses of $\mathrm{N}$ and $\mathrm{C}$, respectively, in living vegetation, $V_{\mathrm{CN}}$ is the mean annual carbon-to-nitrogen ratio of vegetation as determined from literature data (Appendix 2), and $L_{\mathrm{NC}}$ is the steady-state $\mathrm{N}$ concentration of litterfall. The value of $L_{\mathrm{NC}}$ is determined during calibration of the model so that the $\mathrm{C}: \mathrm{N}$ ratio of vegetation equals $V_{\mathrm{CN}}$ on an annual basis. The relationship in Eq. 1.18 causes the $\mathrm{N}$ concentration of litterfall to increase as the $\mathrm{N}$ concentration of vegetation increases, thereby helping to maintain the $\mathrm{C}_{V}: \mathrm{N}_{V}$ ratio near $V_{\mathrm{CN}}$.

Net nitrogen mineralization (NETNMIN) is the amount of inorganic $\mathrm{N}$ produced during decomposition less that immobilized by decomposer organisms. Lacking information on rates of total $\mathrm{N}$ mineralization or of total $\mathrm{N}$ immobilization by heterotrophic organisms, we utilize an empirical approach to model the net of these two fluxes. We predict rates of net $\mathrm{N}$ mineralization from:

$$
\operatorname{NETNMIN~}=\left[\left(N_{\mathrm{up}} \frac{K_{S} \mathrm{~N}_{\mathrm{av}}}{k_{n 2}+\left(K_{S} \mathrm{~N}_{\mathrm{av}}\right)} D\right)+\frac{\mathrm{N}_{S}}{\mathrm{C}_{S}}\right] R_{H},
$$

where $\mathrm{N}_{\mathrm{up}}$ defines the amount of $\mathrm{N}$ immobilized per unit of detrital C respired $(\mathrm{g} / \mathrm{g}), K_{s}$ is as defined in Eq. $1.17, k_{n 2}$ is the half-saturation constant for $\mathrm{N}$ uptake by heterotrophic organisms $\left(\mathrm{g} / \mathrm{m}^{2}\right), D$ is the mean decay state of the detritus (no units), $R_{H}$ is the decomposition rate as defined in Eq. 1.13, and $\mathrm{N}_{\mathrm{av}}, \mathrm{N}_{S}$, and $\mathrm{C}_{S}$ are the amounts of available inorganic $\mathrm{N}$, soil organic $\mathrm{N}$, and soil organic $\mathrm{C}$, respectively (in grams per square metre). The value of $N_{\text {up }}$ was defined during calibration of the model in such a way that $\mathrm{N}_{s}$ remained constant from year to year. We assume that the half-saturation constants for $\mathrm{N}$ uptake by vegetation and heterotrophic organisms $\left(k_{n 1}\right.$ and $\left.k_{n 2}\right)$ are the same.

We derived Eq. 1.19 from empirical data demonstrating an inverse linear relationship between decomposing detritus and the $\mathrm{N}$ concentration of the residue (Aber and Melillo 1980, 1982, Melillo and Aber 1984). There is, for any cohort of litter, a linear relationship between the percentage of original detritus biomass remaining at any given stage of the decomposition process and the $\mathrm{N}$ concentration of that residue:

$$
C / C_{\mathrm{o}}=A(N / C)+b,
$$

where $C$ represents the amount of $C$ remaining in a specific cohort of decomposing litter, $C_{\mathrm{o}}$ represents the original amount of $\mathrm{C}$ in that litter cohort, $A$ is the slope of the linear relationship (in grams of C per gram of $\mathrm{N}$ ), $b$ is the intercept, and $N$ is the amount of $\mathrm{N}$ in the remaining litter. This relationship holds true for decomposition of $80 \%$ of the original biomass (Melillo et al. 1989). Rearranging terms we get:

$$
N=C^{2} / A C_{\mathrm{o}}-b C / A \text {. }
$$

To calculate the rate of change of $\mathrm{N}$ with time (NETNMIN) we take the derivative and rearrange to:

$$
\frac{d N}{d t}=\left[\frac{C}{A C_{\mathrm{o}}}+\frac{C}{A C_{\mathrm{o}}}-\frac{b}{A}\right] \frac{d C}{d t} .
$$

Substituting from (1.20b):

$$
\frac{d N}{d t}=\left[\frac{C}{A C_{\mathrm{o}}}+\frac{N}{C}\right] \frac{d C}{d t} .
$$

Redefining terms in Eq. 1.20d to match those used in TEM we get, for a single cohort of litter:

$$
\text { NETNMIN }=\left[\frac{C}{A C_{\mathrm{o}}}+\frac{N_{S}}{C_{S}}\right] R_{H} .
$$

The value of $A$ is negative, so the first term on the right-hand side of Eq. $1.20 \mathrm{e}$ is interpreted as controlling immobilization (i.e., negative mineralization) of mineral $\mathrm{N}$. We assume that immobilization is hyperbolically related to the amount of available $\mathrm{N}$, as is $\mathrm{N}$ uptake by the vegetation:

$$
\frac{1}{A}=\frac{N_{\mathrm{up}}\left(K_{s}\right) \mathrm{N}_{\mathrm{av}}}{k_{n 2}+\left(K_{s} \mathrm{~N}_{\mathrm{av}}\right)},
$$

where $K_{s}$ is as defined in Eq. 1.17 and the other parameters are as defined in Eq. 1.19. The parameter $N_{\text {up }}$ is negative, as is $A$, and is the mass ratio of $\mathrm{N}$ to $\mathrm{C}$.

Combining Eqs. 1.20e and 1.20f we get, for a cohort of litter:

$$
\text { NETNMIN }=\left[\frac{N_{\mathrm{up}}\left(K_{s}\right) \mathrm{N}_{\mathrm{av}}}{k_{n 2}+\left(K_{s} \mathrm{~N}_{\mathrm{av}}\right)} \frac{C}{C_{\mathrm{o}}}+\frac{\mathrm{N}_{S}}{\mathrm{C}_{S}}\right] R_{H} .
$$

We determine $C / C_{\mathrm{o}}$ from the exponential decay model of Jenny et al. (1949):

$$
C / C_{\mathrm{o}}=e^{k y},
$$

where $k$ is the annual decomposition rate, $y$ represents time (here, in years), and $C$ and $C_{\mathrm{o}}$ are as defined in Eq. 1.20a. We determine the annual value of $k$ by summing the monthly values of $K_{d}$ as modified by monthly temperatures and soil moisture:

$$
k=\sum_{j=1}^{12}\left(K_{d} e^{0.0693 T_{j}} \mathrm{MOIST}_{j}\right),
$$

where the time step $j$ is one month and the other parameters are as described in Eqs. 1.13 and $1.14 \mathrm{a}$ and $\mathrm{b}$. Temperature and moisture influence NETNMIN by influencing $R_{H}$ and the value of $k$.

Aggregated net $\mathrm{N}$ mineralization from all (vs. one) litter cohorts is estimated by determining a mean value of $C / C_{\mathrm{o}}$ and assuming that this applies to the entire active litter fraction. We estimate the mean decay state, $D$, of the active litter as equal to the mean $C / C_{\mathrm{o}}$ of the most recent six years of litter inputs:

$$
D=1 / 6 \sum_{y=1}^{6}\left(e^{k y}\right)
$$

where $y$ is the age in years of the litter cohort. Older cohorts of litter contribute little to the immobilization of N (D only affects the immobilization term in Eq. 1.19).

Nitrogen inputs (NINPUT) include all $\mathrm{N}$ inputs to the ecosystem in precipitation and dry deposition, as well as all atmospheric $\mathrm{N}$ that is fixed into organic materials by biota within the ecosystem. All external inputs of $\mathrm{N}$ to the ecosystem are placed into the available soil $\mathrm{N}$ pool. Nitrogen inputs are estimated from literature data for each of the sites used to calibrate TEM (Appendix 2), and these site-specific inputs are extrapolated across regions by assuming constant annual inputs within a given vegetation type. Monthly additions are proportioned according to monthly rainfall.

Nitrogen losses (NLOST) from ecosystems include gaseous losses of nitrogenous compounds, losses of soluble inorganic and organic $\mathrm{N}$ compounds, and all losses from other processes such as erosion, volatilization during fire, windblown dust, etc. Annual $\mathrm{N}$ losses are assumed to equal annual $\mathrm{N}$ inputs during model calibration. As with NINPUT, all $\mathrm{N}$ losses in TEM occur from the available soil $\mathrm{N}$ pool, $\mathrm{N}_{\mathrm{av}}$. We model $\mathrm{N}$ losses as a linear function of $\mathrm{N}_{\mathrm{av}}$ :

$$
\begin{aligned}
\text { NLOSS } & =\frac{(\text { annual } \mathrm{N} \text { losses })}{12\left(\text { mean annual } \mathrm{N}_{\mathrm{av}}\right)} \\
\mathrm{NLOST}_{t} & =\left(\mathrm{N}_{\mathrm{av}}\right)_{t} \text { NLOSS },
\end{aligned}
$$


TABle A6. Vegetation types in South America as defined for the Terrestrial Ecosystem Model, and their presumed rooting depth classes. The distribution of each type is shown in Fig. 2. Relationships among the vegetation types we defined and other global classifications are also shown.

\begin{tabular}{lcll}
\hline \hline \multicolumn{1}{c}{ Vegetation type } & $\begin{array}{c}\text { Matthews' (1983a) } \\
\text { map symbol* }\end{array}$ & $\begin{array}{c}\text { UNESCO (1973) } \\
\text { formations }\end{array}$ & Rooting depth class $\dagger$ \\
\hline Tropical evergreen forest & $1,2,3$ & 1. A.1-5 & Mature forest \\
Tropical deciduous forest & 9 & 1. B.1 & Mature forest \\
Temperate forest & $3,4, \mathrm{~A}$ & 1. A.6, 1.B.2 & Mature forest \\
Xeromorphic forest & $\mathrm{C}, \mathrm{1}$.C., 2.C & Orchards \\
Savanna & $\mathrm{N}, \mathrm{O}, \mathrm{P}$ & 5.A-C.1-4 & Orchards \\
Grassland & Q, S & 5.A.5., 5.C.5-7 & Deep-rooted crops \\
Arid shrubland & L, U & 3.C., 4.C & Orchards \\
\hline
\end{tabular}

* Refers to Matthews 1983a: Table 4.

$\dagger$ Refers to Thornthwaite and Mather 1957: Table 10.

where $t$ represents the 1 -mo time step of the calculation. Mean annual $\mathrm{N}_{\mathrm{av}}$ and annual $\mathrm{N}$ losses are defined from literature data for each calibration site. These define the value of NLOSS, which is assumed to be constant within each vegetation type.

\section{Carbon-nitrogen interactions}

We model the influence of varying availabilities of either $\mathrm{C}$ or $\mathrm{N}$ on plant production by modifying Ac, the relative allocation of effort to $\mathrm{C}$ vs. $\mathrm{N}$ uptake (i.e., allocation of biomass, enzymes, energy, etc.). The parameter Ac is a unitless multiplier ranging from 0 to 1 that influences GPP and NUPTAKE in Eqs. 1.6 and 1.16, respectively. We initially define Ac to be 0.5, assuming that equal effort is allocated to both $\mathrm{C}$ and $\mathrm{N}$ uptake under the initial steady-state conditions at which the model was calibrated. The magnitude of Ac changes if the $C: N$ of the vegetation changes:

$$
\frac{d \operatorname{Ac}}{d t}=\operatorname{ADAPT} \frac{\left(V_{\left.\mathrm{CN}_{\mathrm{N}} \mathrm{N}_{l}\right)-\mathrm{C}_{l}}\right.}{\left(V_{\mathrm{CN}_{\mathrm{N}}} \mathrm{N}_{l}\right)+\mathrm{C}_{l}}
$$

where $V_{\mathrm{CN}}$ is the mean C:N mass ratio of vegetation as defined by the site-specific data used to calibrate the model. The parameter ADAPT defines the rate of adaptation of the vegetation to changing nutrient abundances, and is a priori defined as $0.001 \mathrm{mo}^{-1}$. This parameter affects the response time of the model but not the equilibrium behavior. Its magnitude therefore has no influence on the results presented herein. Varying the relative availability of either $\mathrm{C}$ or $\mathrm{N}$ results in an altered $\mathrm{C}: \mathrm{N}$ of the vegetation. To maintain constant conditions from year to year, effort is shifted to favor the uptake of the element that is relatively more limiting, thereby maintaining the plant $\mathrm{C}: \mathrm{N}$ ratio near that of the initial conditions $\left(V_{C N}\right)$. For instance, fertilization may increase the availability of $\mathrm{N}$ without directly influencing $\mathrm{C}$ availability. In this case more effort (to a maximum of $<1.0$ ) would be allocated to $\mathrm{C}$ uptake, and less to $\mathrm{N}$ uptake. Growth would increase because the amount of $\mathrm{N}$ per unit effort would increase and more effort would be expended on $\mathrm{C}$ uptake. The theoretical basis for this relationship is more fully detailed in Rastetter and Shaver (1992).

\section{ENVIRonmental Data USED to Run TEM}

All continental-scale information on vegetation, soils, and climate used as independent variables in TEM is maintained in georeferenced databases organized in a geographic information system (GIS). Information on vegetation type and soil texture was used to correctly apply soil- and vegetation-specific parameter values during model runs (Tables A3 and A5). Climate data (temperatures, precipitation, AET, PET, soil moisture, and solar irradiance) were used as independent driving variables. Sources used to develop these data sets are shown in Table 2. No modifications of the original sources were necessary to use the temperature, precipitation, or soil texture data. Temperatures refer to mean monthly surfaceair temperatures, and precipitation refers to mean monthly precipitation.

We used Matthews' $(1983 b)$ digitized map as the basis for our vegetation classification by combining similar vegetation classes into seven broad vegetation types (Table A6), each of which is assumed to represent a relatively uniform type with respect to the ecosystem processes being modelled. The final vegetation map (Fig. 2) was derived by modifying the vegetation types defined from Matthews (1983b) to better resolve borders, to eliminate mismatches between vegetation and climate, to classify coastal vegetation in areas not included in the original database, and to identify wetland areas. Mismatches resulted from the use of independently derived vegetation and climate data bases that differed in their spatial resolution. For instance, tropical evergreen forests were found to occur (in our data sets) in locations receiving $<500 \mathrm{~mm}$ of annual rainfall, and having dry seasons in excess of 6-mo duration. In these and similar cases we accepted the climate data and modified the vegetation type to match the prevailing climate. Modifications to the Matthews (1983b) vegetation classification closely followed the vegetation map of Morello (1985). The relationship between our vegetation types and the vegetation formations defined by UNESCO is shown in Table A6.

Photosynthetically active radiation (PAR) received at canopy level was estimated by first calculating global solar irradiance following Turton (1986). We attenuated global irradiance by percentage of cloud cover (Hahn et al. 1988) using the correction of Black (1956, as cited in Chang 1968) to calculate net solar irradiance. The irradiance of PAR was estimated from net irradiance by assuming that the proportion of PAR in solar radiation increases linearly from $45 \%$ to $65 \%$ as mean monthly cloud cover increases from 0 to $100 \%$. This latter relationship is based on the works of McCree (1966) and Stigter and Musabilha (1982), and is consistent with the observation that the proportion of solar radiation in the photosynthetically active spectrum is $\approx 0.45$ under cloud-free skies (Meek et al. 1984).

Mean monthly soil moisture, potential evapotranspiration, and estimated actual evapotranspiration were determined with our water-balance model (WBM, Vörösmarty et al. 1989), which is based on Thornthwaite and Mather (1957). Precipitation, soil texture, elevation, and air temperature inputs to the WBM are as shown in Table 2. Rooting-depth classes used in calculations of soil water storage capacity are shown in Table A6. We refer to AET as determined by Vörösmarty et al. (1989) as EET, or estimated evapotranspiration, to emphasize that this is a model-generated estimate. 


\section{APPENDIX 2}

\section{SITE-SPECIFIC DATA}

Sites for which data were collated from the literature for calibration of the Terrestrial Ecosystem Model (Table 1) are described herein. Brief site descriptions are followed by tables describing the data used to calibrate the model and to initialize the state variables prior to model runs, and by sources of these data. We assumed that NPP $=L_{\mathrm{C}}=R_{H}$, NUPTAKE $=L_{\mathrm{N}}=$

NETNMIN, and NINPUT $=$ NLOST during calibration of the model. All acronyms are defined in Table A1 and described in Appendix 1. We convert plant and litter biomass to carbon using a carbon to organic matter ratio of 0.475 , and assume soil organic matter to be $58 \% \mathrm{C}$.

TABLE A7. Grassland: Osage prairie, Oklahoma, USA. $36^{\circ} 57^{\prime} \mathrm{N}, 96^{\circ} 33^{\prime} \mathrm{W}$. Elevation $392 \mathrm{~m}$. Ungrazed tallgrass prairie. International Biological Program (IBP) site. Soils are silty clay Haplustolls with a surface-soil pH of 5.9.

\begin{tabular}{|c|c|c|}
\hline Variable & Value & Source and comments \\
\hline $\mathrm{C}_{V}$ & 620 & Estimated mean based on Risser et al. (1981) and Sims and Coupland (1979). \\
\hline $\mathrm{N}_{V}$ & & Estimated mean based on Risser et al. (1981) and Bokhari and Singh (1975). \\
\hline$V_{\mathrm{CN}}$ & 113 & . \\
\hline $\mathrm{C}_{S}$ & 16000 & $\begin{array}{l}\text { Soil C calculated from } N \text {, bulk density, and organic matter to } N \text { ratios by horizon to } 100 \mathrm{~cm} \\
\text { depth (Risser et al. 1981, Risser and Parton 1982). Litter data from Sims et al. (1978). }\end{array}$ \\
\hline $\mathbf{N}_{S}$ & 1550 & Risser et al. (1981), Risser and Parton (1982). \\
\hline $\mathrm{N}_{\mathrm{av}}$ & 4 & To 40-cm depth (Risser and Parton 1982). \\
\hline NPP & 470 & Aboveground (Risser and Parton 1982) plus belowground (Risser et al. 1981). \\
\hline NUPTAKE & 5.5 & $\begin{array}{l}\text { Mean of two estimates of total } \mathrm{N} \text { uptake by vegetation (Risser et al. 1981, Risser and Parton } \\
\text { 1982). }\end{array}$ \\
\hline NINPUT & 1 & Woodmansee (1979). \\
\hline
\end{tabular}

TABle A8. Savanna: Nylsvley Nature Reserve, South Africa. $24^{\circ} 39^{\prime}$ S, $28^{\circ} 42^{\prime}$ E. Deciduous, broad-leaved woodland on sandy, nutrient-poor soils. Burns every 5-8 yr.

\begin{tabular}{lcl}
\hline \hline \multicolumn{1}{c}{ Variable } & Value & \\
\hline $\mathrm{C}_{V}$ & 1460 & Mean annual value (R. J. Scholes, personal communication). \\
$\mathrm{N}_{V}$ & 25.5 & Mean annual value (R. J. Scholes, personal communication). \\
$V_{\mathrm{CN}}$ & 57.3 & $\mathrm{C}_{V} / \mathrm{N}_{V}$. \\
$\mathrm{C}_{S}$ & 7970 & $\begin{array}{l}\text { Soil organic C from R. J. Scholes (personal communication). Aboveground litter data from Frost } \\
(1985) .\end{array}$ \\
$\mathrm{N}_{S}$ & 375 & Frost (1985). \\
$\mathrm{N}_{\mathrm{av}}$ & 1 & R. J. Scholes (personal communication). \\
$\mathrm{NPP}$ & 435 & R. J. Scholes (personal communication). \\
NUPTAKE & 10 & R. J. Scholes (personal communication). \\
NINPUT & 0.7 & Bulk precipitation from Frost (1985). Total N fixation estimated as 0.5 (R. J. Scholes personal \\
& & communication). \\
\hline
\end{tabular}

TABle A9. Arid shrubland: Reserva Ecológica de Ñacuñan, Mendoza Province, Argentina. $67^{\circ} 58^{\prime}$ W, $34^{\circ} 02^{\prime}$ S. Elevation $572 \mathrm{~m}$. 50-yr-old, open, xerophytic forest. Soils are Torripsamments of sandy loam texture.

\begin{tabular}{|c|c|c|}
\hline Variable & Value & Source and comments \\
\hline $\mathrm{C}_{V}$ & 680 & $\begin{array}{l}\text { Shrubs biomass from Braun (1982). Shrub root: shoot ratio assumed same as 8-yr-old vegeta- } \\
\text { tion. Herb biomass after Braun et al. (1978). }\end{array}$ \\
\hline $\begin{array}{l}\mathrm{N}_{V} \\
V_{\mathrm{CN}}\end{array}$ & $\begin{array}{l}19 \\
35.8\end{array}$ & $\begin{array}{l}\text { Same sources as } \mathrm{C}_{V} \text { (above). } \mathrm{N} \text { concentrations of roots from 8-yr-old site. } \\
\mathrm{C}_{V} / \mathrm{N}_{V} \text {. }\end{array}$ \\
\hline $\mathrm{C}_{S}$ & 3325 & $\begin{array}{l}\text { Litter mass from Braun et al. (1978). Soil organic matter estimated from Tanquilevich (1971), } \\
\text { assuming a soil bulk density of } 1.3 \mathrm{~g} / \mathrm{cm}^{3} \text {. }\end{array}$ \\
\hline $\mathbf{N}_{S}$ & 480 & $\begin{array}{l}\text { Litter } N \text { concentration from Braun (1982). Soil } \mathrm{N} \text { estimated from Tanquilevich (1971), assum- } \\
\text { ing a soil bulk density of } 1.3 \mathrm{~g} / \mathrm{cm}^{3} \text {. }\end{array}$ \\
\hline $\mathrm{N}_{\mathrm{av}}$ & 6 & Estimated; no data available. \\
\hline NPP & 110 & $\begin{array}{l}\text { Total aboveground NPP from Braun (1982). Root NPP calculated from (root NPP)/(above- } \\
\text { ground NPP) for 8-yr-old site. }\end{array}$ \\
\hline NUPTAKE & 3 & Estimated from NPP and N concentrations in different plant organs presented by Braun (1982). \\
\hline NINPUT & 0.1 & Estimated; no data available. \\
\hline
\end{tabular}


TABLE A10. Tropical deciduous forest: Chakia, India. $25^{\circ} 20^{\prime} \mathrm{N}, 83^{\circ} \mathrm{E}$. Elevation $350 \mathrm{~m}$. Approximately 60 -yr-old droughtdeciduous forest. International Biological Program (IBP) site. Soil pH: 6.7; soil texture: sandy clay loam.

\begin{tabular}{|c|c|c|}
\hline Variable & Value & Source and comments \\
\hline$\overline{C_{1}}$ & 11153 & Bandhu (1970). \\
\hline $\mathrm{N}_{1}^{\prime}$ & 168 & Ramam (1975). \\
\hline$V_{\mathrm{CN}}$ & 66.4 & $\mathrm{C}_{1} / \mathrm{N}_{l}$ \\
\hline $\mathrm{C}_{S}$ & 7880 & To $50 \mathrm{~cm}$ depth only (Misra 1972). \\
\hline $\mathbf{N}_{s}$ & 950 & To $50 \mathrm{~cm}$ depth only (Misra 1972). \\
\hline $\mathrm{N}_{\mathrm{av}}$ & 2 & Estimated; no data available. \\
\hline NPP & 700 & $\begin{array}{l}\text { Aboveground NPP from Bandhu in DeAngelis et al. (1981). Root NPP assumed equal to lit- } \\
\text { terfall. }\end{array}$ \\
\hline NUPTAKE & 27 & Total N uptake (Ramam 1975). \\
\hline NINPUT & 1.5 & Precipitation inputs only (Misra 1972). \\
\hline
\end{tabular}

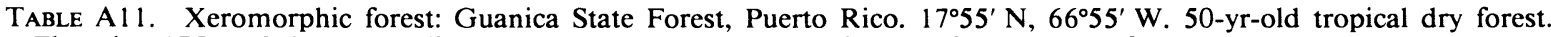
Elevation $175 \mathrm{~m}$. Soils are Mollisols averaging $<1 \mathrm{~m}$ in depth with a surface-soil pH of 7.8.

\begin{tabular}{|c|c|c|}
\hline Variable & Value & Source and comments \\
\hline $\mathrm{C}_{\mathrm{v}}$ & 4270 & Murphy and Lugo (1986). \\
\hline $\mathbf{N}_{1}$ & 91.6 & Lugo and Murphy (1986). \\
\hline$V_{\mathrm{C} N}$ & 46.6 & $\mathrm{C}_{1} / \mathrm{N}_{1}$ \\
\hline $\mathrm{C}_{S}$ & 11140 & Lugo and Murphy (1986) and Murphy and Lugo (1986). \\
\hline $\mathbf{N}_{S}$ & 940 & Lugo and Murphy (1986) and Murphy and Lugo (1986). \\
\hline $\mathrm{N}_{\mathrm{av}}$ & 5 & Estimated; no data available. \\
\hline NPP & 555 & $\begin{array}{l}\text { Aboveground NPP from Lugo and Murphy (1986). Root net production assumed equal to } \\
\text { litterfall. }\end{array}$ \\
\hline NUPTAKE & 14 & $\begin{array}{l}\text { Aboveground } \mathrm{N} \text { requirements from Lugo and Murphy (1986). Belowground requirements esti- } \\
\text { mated from root production and mean } \mathrm{N} \text { content of all roots. }\end{array}$ \\
\hline NINPUT & 0.5 & Estimated; no data available. \\
\hline
\end{tabular}

TABle A12. Temperate forest: Taita Experimental Station, North Island, New Zealand. $41^{\circ} 11^{\prime}$ S, $174^{\circ} 58^{\prime}$ E. Approximately 100 -yr-old evergreen Nothofagus forest on steep slopes. Silt loam soils with a well-developed 0 horizon and a pH of 4.7 in the surface mineral soil. Soil depth $40 \mathrm{~cm}$.

\begin{tabular}{|c|c|c|}
\hline Variable & Value & Source and comments \\
\hline$\overline{C_{1}}$ & $15000 \mathrm{~g} / \mathrm{m}^{2}$ & Miller (1963a). \\
\hline $\mathbf{N}_{1}$ & 42 & Trees only, one tree sampled (Miller 1963a). \\
\hline$V_{\mathrm{CN}}$ & 357 & $\mathrm{C}_{1} / \mathrm{N}_{1}$ \\
\hline $\mathrm{C}_{\mathrm{s}}$ & 13000 & $\begin{array}{l}\text { Soil organic } C \text { to } 40 \mathrm{~cm} \text { depth from Dutch and Stout (1968). Fine litter from Miller } \\
(1963 a) \text {. Standing-dead biomass estimated from data in Miller }(1963 a) \text { assuming a bio- } \\
\text { mass : basal area of } 50 \% \text { that of live trees. }\end{array}$ \\
\hline $\mathbf{N}_{s}$ & 460 & $\begin{array}{l}\text { Total soil } \mathrm{N} \text { to } 40 \mathrm{~cm} \text { depth from Miller (1968). Litter } \mathrm{N} \text { from Miller (1963a). Standing- } \\
\text { dead } \mathrm{N} \text { based on assumed } \mathrm{N} \text { content of } 0.3 \% \text {. }\end{array}$ \\
\hline $\mathrm{N}_{\mathrm{av}}$ & 1 & Estimated; no available data. \\
\hline NPP & 726 & $\begin{array}{l}\text { Litterfall from Miller }(1963 b) \text {. Bole growth from Dutch and Stout }(1968) \text {. Large root } \\
\text { growth estimated from root to shoot ratio of trees }(0.15 \text {, Miller } 1963 a) \text { times stemwood } \\
\text { NPP. Fine root production assumed equal to litterfall. }\end{array}$ \\
\hline NUPTAKE & 6 & $\begin{array}{l}\mathrm{N} \text { in litterfall plus leaching by precipitation from Miller }(1963 b) . \mathrm{N} \text { requirement for bole } \\
\text { and root growth estimated from } \mathrm{N} \text { concentrations (Miller 1963a) and estimated growth. }\end{array}$ \\
\hline NINPUT & 0.5 & Precipitation only (Miller 1968). \\
\hline
\end{tabular}


TABLE A 13. Evergreen forest: Banco plateau, Ivory Coast. $5^{\circ} 23^{\prime} \mathrm{N}, 4^{\circ} 2^{\prime} \mathrm{W}$. Elevation $50 \mathrm{~m}$. Tropical evergreen broad-leaved forest. Soils "ferralitiques fortement lessivés" (probably Udults) of loamy sand texture.

\begin{tabular}{|c|c|c|}
\hline Variable & Value & Source and comments \\
\hline $\mathrm{C}_{1}$ & 26700 & Bernhard-Reversat et al. (1978). \\
\hline $\mathrm{N}_{1}$ & 154 & Bernhard-Reversat (1975). \\
\hline$V_{\mathrm{C} N}$ & & $\mathrm{C}_{1} / \mathrm{N}_{1}$ \\
\hline $\mathrm{C}_{S}$ & 21700 & $\begin{array}{l}\text { Soil C to } 50 \mathrm{~cm} \text { depth (Bernhard-Reversat et al. 1978). Soil C at } 50-100 \mathrm{~cm} \text { based on depth } \\
\text { profile (Bernhard-Reversat 1974) and bulk density at } 100 \mathrm{~cm} \text { (Huttel and Bernhard-Rever- } \\
\text { sat 1975). Litter mass from Bernhard-Reversat in DeAngelis et al. (1981). }\end{array}$ \\
\hline $\mathbf{N}_{s}$ & 990 & $\begin{array}{l}\text { Soil } N \text { to } 50 \mathrm{~cm} \text { depth (Bernhard-Reversat et al. 1978). Soil } \mathrm{N} \text { at } 50-100 \mathrm{~cm} \text { calculated as for } \\
\text { soil C (see above). Litter } N \text { from Bernhard-Reversat (1974). }\end{array}$ \\
\hline $\mathrm{N}_{\mathrm{av}}$ & 1.2 & Surface soil only (Bernhard-Reversat 1974). \\
\hline NPP & 1370 & $\begin{array}{l}\text { Aboveground and large root NPP from Bernhard-Reversat et al. (1978). Fine root production } \\
\text { assumed equal to litterfall. }\end{array}$ \\
\hline NUPTAKE & 36 & $\begin{array}{l}\text { Total } N \text { requirement for aboveground and large root NPP (Bernhard-Reversat et al. 1978) } \\
\text { plus estimated } N \text { uptake by fine roots, assuming } 1 \% \mathrm{~N} \text { in fine root production. }\end{array}$ \\
\hline NINPUT & 2.1 & Rainfall only (Bernhard-Reversat et al. 1978). \\
\hline
\end{tabular}

TABle A14. Evergreen forest: Ducke Forest, Manaus, Brazil, $2^{\circ} 56^{\prime} \mathrm{S}, 59^{\circ} 57^{\prime} \mathrm{W}$. Tropical evergreen broad-leaved forest. International Biological Program (IBP) site. Haplorthox or Acrorthox soils with a clay texture and a surface-soil pH of 4.9 .

\begin{tabular}{|c|c|c|}
\hline Variable & Value & Source and comments \\
\hline $\mathrm{C}_{1}$ & 22470 & Klinge $(1976 b)$. \\
\hline$N_{1}$ & 298 & Klinge $(1976 b)$. \\
\hline$V_{\mathrm{CN}}$ & 75.4 & $\mathrm{C}_{1} / \mathrm{N}_{1}$ \\
\hline $\mathrm{C}_{s}$ & 15030 & Klinge (1976b). \\
\hline $\mathbf{N}_{S}$ & 922 & Klinge $(1976 b)$. \\
\hline $\mathrm{N}_{\mathrm{av}}$ & 1 & Estimated from data in Vitousek and Matson (1988). \\
\hline NPP & 1060 & $\begin{array}{l}\text { Litterfall from Klinge and Rodrigues (1968) and Franken et al. (1979). Wood production esti- } \\
\text { mated from tree mortality rates (Swaine et al. 1987) and wood biomass (Klinge 1976b). } \\
\text { Fine root production estimated from litterfall and soil respiration, the latter as estimated by } \\
\text { Raich and Nadelhoffer (1989). }\end{array}$ \\
\hline NUPTAKE & 24 & $\begin{array}{l}\text { Estimated as the sum of all } \mathrm{N} \text { losses from living vegetation. } \mathrm{N} \text { in litterfall from Klinge and } \\
\text { Rodrigues (1968). } \mathrm{N} \text { leaching from foliage from Leopoldo et al. (1987). } \mathrm{N} \text { losses in bole } \\
\text { mortality and fine root production estimated from } \mathrm{N} \text { contents in these components (Klinge } \\
1976 a, b) \text {. }\end{array}$ \\
\hline NINPUT & 2 & Estimated. \\
\hline
\end{tabular}

TABle A 15. Evergreen forest: El Verde, Puerto Rico. $18^{\circ} 20^{\prime} \mathrm{N}, 65^{\circ} 20^{\prime} \mathrm{W}$. Elevation $510 \mathrm{~m}$. Tropical evergreen broad-leaved forest. Dominant soils are silty clay loam Epiaquic Tropohumults, 1 to $1.5 \mathrm{~m}$ deep, with a surface-soil pH of 4.4 .

\begin{tabular}{|c|c|c|}
\hline Variable & Value & Source and comments \\
\hline$\overline{C_{1}}$. & 13000 & Odum (1970) \\
\hline $\mathrm{N}_{1}$ & 123 & Edmisten (1970). \\
\hline$V_{\mathrm{CN}}$ & 106 & $\mathrm{C}_{1} / \mathrm{N}_{1}$ \\
\hline $\mathrm{C}_{S}$ & 8000 & Soil C to $60 \mathrm{~cm}$ depth based on Brown et al. (1983). Litter mass from Odum (1970). \\
\hline $\mathbf{N}_{S}$ & 750 & Soil $\mathrm{N}$ to $60 \mathrm{~cm}$ depth based on Brown et al. (1983). Litter $\mathrm{N}$ from Edmisten (1970). \\
\hline $\mathrm{N}_{\mathrm{av}}$ & 1 & Estimated; no available data. \\
\hline NPP & 1040 & $\begin{array}{l}\text { Aboveground NPP from Odum }(1970) \text {. Large root turnover based on large root biomass and } \\
\text { aboveground bole turnover rates. Fine root NPP estimated from litterfall and soil respiration, } \\
\text { the latter as reported by E. Cuevas (personal communication). }\end{array}$ \\
\hline NUPTAKE & 25 & $\begin{array}{l}\text { Estimated as } N \text { leaching from foliage plus the total } N \text { flux in NPP, based on estimates of NPP } \\
\text { by component and } N \text { concentrations in the different components as reported by Odum (1970) } \\
\text { and Edmisten (1970). }\end{array}$ \\
\hline NINPUT & 10 & Precipitation plus estimated $N$ fixation (Edmisten 1970). \\
\hline
\end{tabular}


TABLE A 16. Evergreen forest: Kade, Ghana. $6^{\circ} 09^{\prime} \mathrm{N}, 0^{\circ} 55^{\prime} \mathrm{W}$. Elevation $150 \mathrm{~m}$. Tropical moist semi-deciduous forest. Soils are Paleudults of clay loam texture with a surface-soil pH of 5.3.

\begin{tabular}{|c|c|c|}
\hline Variable & Value & Source and comments \\
\hline $\begin{array}{l}\mathrm{C}_{1} \\
\mathrm{~N}_{1} \\
V_{(\cdot \mathrm{N}}\end{array}$ & $\begin{array}{r}13630 \\
180 \\
75.7\end{array}$ & $\begin{array}{l}\text { Greenland and Kowal (1960). } \\
\text { Greenland and Kowal }(1960) \text {. } \\
C_{1} / N_{1}\end{array}$ \\
\hline $\mathrm{C}_{S}$ & 12600 & $\begin{array}{l}\text { Litter and soil to } 30 \mathrm{~cm} \text { depth from Greenland and Kowal (1960). Soil C at } 30-100 \mathrm{~cm} \text { esti- } \\
\text { mated from } N \text { content (see below) and a mean C:N of 10, based on data in Asamoa (1980) } \\
\text { and Greenland and Kowal (1960). }\end{array}$ \\
\hline $\mathbf{N}_{S}$ & 960 & $\begin{array}{l}\text { Litter and soil to } 30 \mathrm{~cm} \text { depth from Greenland and Kowal }(1960) \text {. N concentrations at } 30-100 \\
\text { cm from Asamoa (1980). Bulk density estimated to be } 1.4 \mathrm{~g} / \mathrm{cm}^{3} \text { following Robertson and } \\
\text { Rosswall (1986). }\end{array}$ \\
\hline $\mathrm{N}_{\mathrm{av}}$ & & Estimated; no data available. \\
\hline NPP & 1150 & $\begin{array}{l}\text { Litterfall from Nye (1961) and John (1973). Wood production based on wood biomass } \\
\text { (Greenland and Kowal 1960) times mortality rate of } 1.77 \% / \mathrm{yr} \text { (Swaine et al. 1987). Nye's } \\
\text { (1961) estimates of wood production indicate a turnover of } 5 \% / y r \text {. Fine root production } \\
\text { assumed equal to litterfall. }\end{array}$ \\
\hline NUPTAKE & 33 & $\begin{array}{l}\mathrm{N} \text { in aboveground production from Nye }(1961) \text {, corrected for a presumed lower timberfall } \\
\text { rate. Fine root } \mathrm{N} \text { requirement estimated as } 1 \% \text { of fine root NPP. }\end{array}$ \\
\hline NINPUT & 3 & Rainfall (Nye 1961) plus estimated N fixation (Robertson and Rosswall 1986). \\
\hline
\end{tabular}

TABle A17. Evergreen forest: Pasoh Forest, peninsular Malaysia. $2^{\circ} 58^{\prime} \mathrm{N}, 102^{\circ} 18^{\prime}$ E. Elevation $100 \mathrm{~m}$. Tropical evergreen broad-leaved dipterocarp forest. International Biological Program (IBP) site. Soils of main study plots are silty loam Tropudults with a surface-soil $\mathrm{pH}$ of 4.5 .

\begin{tabular}{|c|c|c|}
\hline Variable & Value & Source and comments \\
\hline$\overline{C_{1}}$ & 25760 & $\begin{array}{l}\text { Aboveground biomass (Kato et al. 1978) plus small root biomass (Yoda 1978) plus assumed } \\
\text { large root biomass of } 10 \% \text { of bolewood biomass. }\end{array}$ \\
\hline $\mathrm{N}_{1}$ & 160 & $\begin{array}{l}\text { Estimated from biomass data and } \mathrm{N} \text { concentration of different tissues. Wood } \mathrm{N} \text { determined } \\
\text { from the } \mathrm{N} \text { concentration of grade } 0 \text { fallen boles (Ogawa 1978). Small root } \mathrm{N} \text { based on an } \\
\text { assumed } \mathrm{N} \text { concentration of } 0.5 \% \text {. Leaf and twig } \mathrm{N} \text { estimated as twice the amount of } \mathrm{N} \\
\text { present in litterfall. }\end{array}$ \\
\hline$V_{\mathrm{CN}}$ & 161 & $\mathrm{C}_{1} / \mathrm{N}_{1}$ \\
\hline $\mathrm{C}_{S}$ & 9600 & To $1 \mathrm{~m}$ depth in soil, including litter and dead wood (Ogawa 1978). \\
\hline & 643 & To $1 \mathrm{~m}$ depth in soil, including litter and dead wood (Ogawa 1978). \\
\hline$N_{\mathrm{av}}$ & & Estimated; no data available. \\
\hline NPP & 1300 & $\begin{array}{l}\text { Aboveground NPP from Bullock in DeAngelis et al. (1981). Fine root production estimated as } \\
50 \% \text { of difference between annual soil respiration (Ogawa 1978) and annual fine litterfall. }\end{array}$ \\
\hline NUPTAKE & 24 & $\begin{array}{l}\text { Litterfall N (Lim 1978) plus canopy leaching (Manokaran 1980) plus estimated N require- } \\
\text { ments for bole and fine root NPP, assuming fine roots are } 1 \% \mathrm{~N} \text {. }\end{array}$ \\
\hline NINPUT & 1.4 & Precipitation only (Yoda and Kira 1982). \\
\hline
\end{tabular}

TABLE A18. Evergreen forest: San Carlos, Venezuela. $1^{\circ} 56^{\prime} \mathrm{N}, 67^{\circ} 03^{\prime} \mathrm{W}$. Elevation $120 \mathrm{~m}$. Mature, evergreen, broad-leaved terra firme forest on Oxisols. Soils are sandy clay loams to clay loams. Surface-soil pH is about 3.2, but all soil data are extremely variable.

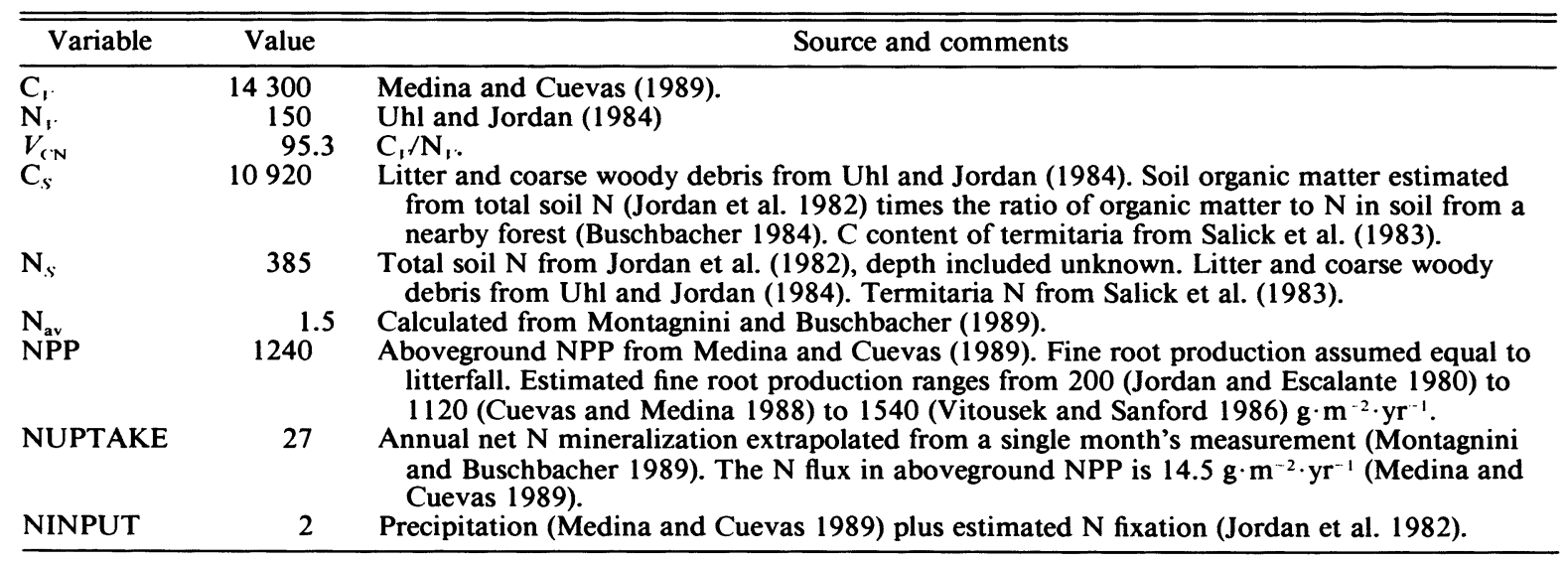

